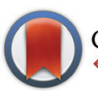

CrossMark \& click for updates

Cite this: Dalton Trans., 2015, 44 12149

Received 18th December 2014,

Accepted 3rd February 2015

DOI: $10.1039 / c 4 d t 03916 e$

www.rsc.org/dalton

\title{
Intermolecular hydroaminoalkylation of alkenes and dienes using a titanium mono(formamidinate) catalyst $\uparrow$
}

\author{
Jaika Dörfler, Till Preuß, Christian Brahms, Dennis Scheuer and Sven Doye*
}

\begin{abstract}
An easily accessible formamidinate ligand-bearing titanium complex initially synthesized by Eisen et al. is used as catalyst for intermolecular hydroaminoalkylation reactions of unactivated, sterically demanding 1,1- and 1,2-disubstituted alkenes and styrenes with secondary amines. The corresponding reactions, which have never been achieved with titanium catalysts before, take place with excellent regioselectivity (up to $99: 1$ ) and in addition, corresponding reactions of 1,3-butadienes with $N$-methylbenzylamine are also described for the first time.
\end{abstract}

\section{Introduction}

The direct addition of $\alpha-\mathrm{C}\left(\mathrm{sp}^{3}\right)-\mathrm{H}$ bonds of primary or secondary amines across $\mathrm{C}-\mathrm{C}$ double bonds, the so-called hydroaminoalkylation of alkenes, represents a very promising and atomefficient approach towards the synthesis of various nitrogencontaining molecules. ${ }^{1}$ Due to the fact that the formed $\alpha$-alkylated amines are of great importance in the agrochemical, fine chemical and pharmaceutical industries ${ }^{2}$ a plethora of suitable hydroaminoalkylation catalysts has already been identified in recent years. ${ }^{3-7}$ Although hydroaminoalkylation reactions can be achieved in the presence of ruthenium, ${ }^{3}$ iridium, ${ }^{4}$ group 5 metal, ${ }^{5}$ zirconium, ${ }^{6}$ or titanium catalysts ${ }^{7}$ a number of limitations in scope still exists. For example, ruthenium and iridium catalysts can only be used for hydroaminoalkylation reactions of amine substrates bearing a directing 2-pyridinyl substituent bound to the nitrogen atom of the amine., Furthermore, zirconium complexes only catalyze intramolecular hydroaminoalkylation reactions of primary aminoalkenes. ${ }^{6}$ On the other hand, group 5 metal $^{5}$ and titanium catalysts ${ }^{7}$ have successfully been applied for the intermolecular hydroaminoalkylation of alkenes, styrenes and 1,3-butadienes. For example, the conversion of styrene (1) into the corresponding hydroaminoalkylation products $\mathbf{3} \mathbf{a}$ and $\mathbf{3} \mathbf{b}$ (Scheme 1 ) could be achieved in the presence of tantalum or titanium catalysts. $^{5 m, 7 d, g, i}$

In this context, it is worth mentioning that the regioselectivity of hydroaminoalkylation reactions of styrenes can simply

Institut für Chemie, Universität Oldenburg, Carl-von-Ossietzky-Strasse 9-11, D-26111 oldenburg, Germany. E-mail: doye@uni-oldenburg.de

$\dagger$ Electronic supplementary information (ESI) available: Copies of the ${ }^{1} \mathrm{H}$ and ${ }^{13} \mathrm{C}$ NMR spectra of all products. See DOI: 10.1039/c4dt03916e

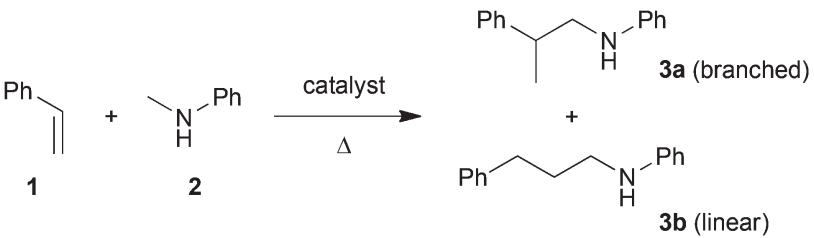

$\mathrm{Ta}\left(\mathrm{NMe}_{2}\right)_{5}\left(8 \mathrm{~mol} \%, 140{ }^{\circ} \mathrm{C}, 96 \mathrm{~h}\right)$ $92 \%(3 a / 3 b=98: 2)^{5 m}$

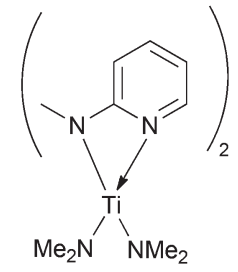

$4\left(10 \mathrm{~mol} \%, 140^{\circ} \mathrm{C}, 96 \mathrm{~h}\right)$ $76 \%(3 a / 3 b=33: 67)^{7 g}$

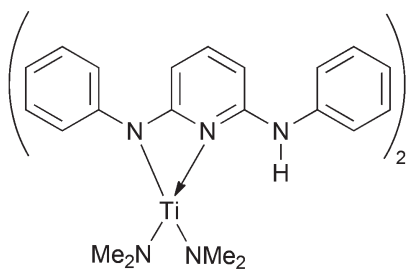

$5\left(5 \mathrm{~mol} \%, 140{ }^{\circ} \mathrm{C}, 96 \mathrm{~h}\right)$ $81 \%(3 a / 3 b=6: 94)^{7 i}$
Scheme 1 Intermolecular hydroaminoalkylation of styrene (1) with $\mathrm{N}$-methylaniline (2) catalyzed by group 4 and group 5 metal catalysts.

be controlled by the nature of the catalyst. Whereas in the presence of $\mathrm{Ta}\left(\mathrm{NMe}_{2}\right)_{5}$, the branched product $3 \mathbf{a}$ is formed almost exclusively, ${ }^{5 m}$ the aminopyridinato titanium catalysts $\mathbf{4}$ and $\mathbf{5}$ favor the formation of the corresponding linear hydroaminoalkylation product $3 \mathbf{b b}^{7 g, i}$ However, so far, the use of titanium catalysts is limited to hydroaminoalkylation reactions of sterically less demanding mono-substituted alkenes, styrenes, or 1,3-butadienes with $N$-alkylanilines or dialkylamines. Among the class of sterically more demanding disubstituted alkenes, only norbornene $e^{7 b-d, g}$ and methylenecyclohexane $e^{7 c, g}$ were found to undergo hydroaminoalkylation reactions in the 
presence of selected titanium catalysts. On the other hand, hydroaminoalkylation reactions of sterically demanding 1,1and 1,2-disubstituted alkenes are well known for group 5 metal catalysts. ${ }^{5 c, e-g, i, k, l, n}$ Most impressively, very recently, Schafer $e t$ al. reported a 2-pyridonate tantalum catalyst that is able to catalyze high-yielding hydroaminoalkylation reactions of sterically demanding $E$ - and $Z$-internal alkenes like cyclohexene, $(E)$ - and $(Z)$-3-hexene, $(Z)-\beta$-methylstyrene or $(E)-1$ - $($ paramethoxyphenyl)propene. ${ }^{5 n}$ In the latter two cases, hydroaminoalkylation at the $\beta$-carbon of the $\beta$-substituted styrene derivatives is favored but only modest regioselectivities (up to $4.4: 1$ ) could be achieved.

The mechanism of group 4 and 5 metal-catalyzed hydroaminoalkylation reactions has already been studied ${ }^{1,5 c, d, i, 6,7 e}$ and it is generally accepted that the amine substrate undergoes $\mathrm{N}-\mathrm{H}$ and $\mathrm{C}-\mathrm{H}$ bond activation in the presence of the catalyst precursor to give a strained metallaaziridine as the catalytically active species. Subsequent alkene insertion into the $\mathrm{M}-\mathrm{C}$ bond of the metallaaziridine which determines the regioselectivity of the over-all transformation then results in the formation of a 2-metallapyrrolidine. Finally, aminolysis of the $\mathrm{M}-\mathrm{C}$ bond of the five membered intermediate and product-forming $\mathrm{C}-\mathrm{H}$ bond activation regenerate the catalytically active metallaaziridine.

Herein, we present the first example of a titanium-based catalyst for intermolecular hydroaminoalkylation reactions of unactivated, sterically demanding 1,1- and 1,2-disubstituted alkenes and styrenes with secondary amines. The corresponding reactions take place with excellent regioselectivity (up to $99: 1$ ) and the formamidinate ligand-bearing catalyst is also capable of catalyzing reactions of 1,3-butadienes with $N$-methylbenzylamine.

\section{Results and discussion}

In order to develop a more efficient catalyst system that is able to expand the substrate scope of the titanium-catalyzed intermolecular hydroaminoalkylation of alkenes, we recently focused on ligand motifs which are structurally similar to the aminopyridinato ligands of the second-generation hydroaminoalkylation catalysts 4 and 5 (Scheme 1). In this context, it must be mentioned that the chelating heteroallylic $\mathrm{N}-\mathrm{C}-\mathrm{N}$ unit of the aminopyridinato ligands that binds to the titanium center can also be found in the well-known class of amidinate ligands $\left[\mathrm{R}^{1}-\mathrm{C}\left(\mathrm{NR}^{2}\right)_{2}\right]^{-}$. A variety of corresponding group 4 amidinate complexes has already been used as catalysts in the polymerization of olefins by Eisen $e t a l^{8}$ and a particular advantage of this class of catalysts is that the ligands are easily prepared and modified. ${ }^{8 a}$ On the other hand, corresponding catalysts have never been used for hydroaminoalkylation reactions of alkenes.

During an investigation of various titanium formamidinate catalysts we found that complex 6 (Scheme 2) which bears 2,6diisopropylphenyl groups as the amidinate $\mathrm{N}$-substituents ${ }^{8 a}$ is a highly active catalyst for the hydroaminoalkylation of styrene (1) with $N$-methylaniline (2). Under usually applied conditions

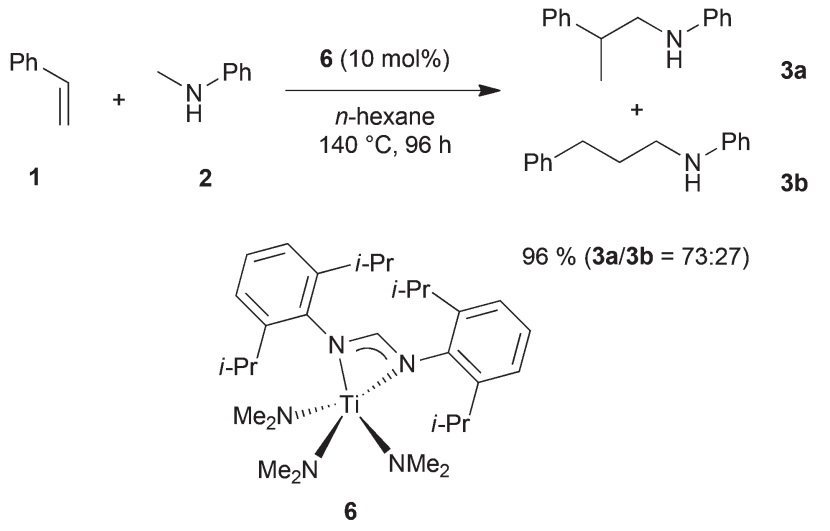

Scheme 2 Intermolecular hydroaminoalkylation of styrene (1) with $\mathrm{N}$-methylaniline (2) catalyzed by titanium mono(formamidinate) complex 6 .

(10 mol\% 6, $n$-hexane, $140{ }^{\circ} \mathrm{C}, 96 \mathrm{~h}$, sealed Schlenk tube), ${ }^{7 g, i}$ the reaction took place smoothly to give a mixture of the two regioisomeric hydroaminoalkylation products $\mathbf{3 a}$ and $\mathbf{3 b}$ in an excellent total yield of $96 \%$. Unfortunately, the regioselectivity of the reaction which in this case, favors the formation of the branched product $\mathbf{3 a}$ was only modest $(\mathbf{3} \mathbf{a} / \mathbf{3} \mathbf{b}=73: 27)$. However, an interesting finding is the fact that in comparison to the structurally related aminopyridinato catalysts $\mathbf{4}$ and $\mathbf{5}$, the regioselectivity is reversed with the formamidinate catalyst 6 .

Impressed by the high catalytic activity of complex 6 and the clean formation of the desired hydroaminoalkylation products $\mathbf{3 a}$ and $\mathbf{3 b}$, we further investigated whether complex $\mathbf{6}$ is also able to catalyze intermolecular hydroaminoalkylation reactions of sterically more demanding disubstituted alkenes with $N$-methylaniline (2, Table 1).

As can be seen from Table 1, a number of successful hydroaminoalkylation reactions of 1,1- and 1,2-disubstituted alkenes and styrenes with $N$-methylaniline (2) can be achieved at elevated temperatures $\left(140-180^{\circ} \mathrm{C}\right)$ in the presence of $10 \mathrm{~mol} \%$ of catalyst 6. For example, methylenecyclohexane (7, Table 1, entries 1 and 2) regioselectively reacted to the corresponding branched amine 21a which could be isolated in excellent yield of $90 \%$. Even though bulky 1,1-diphenylethylene (8) did not react at all under the applied conditions (Table 1, entries 3 and 4), $\alpha$-methylstyrene (9) and para- $\alpha$-dimethylstyrene (10) could be converted regioselectively to the corresponding branched hydroaminoalkylation products 22a and 23a, respectively (Table 1, entries 5-8). In these cases, the yields of the reactions were significantly improved by increasing the reaction temperature from $140{ }^{\circ} \mathrm{C}$ to $180{ }^{\circ} \mathrm{C}$. Finally, it was possible to isolate the branched products 22a and 23a in $86 \%$ and $91 \%$ yield, respectively. Although a corresponding dependence on the reaction temperature had not been observed during the initially performed reactions of methylenecyclohexane ( 7 , Table 1 , entries 1 and 2) we performed most additional reactions presented in Table 1 at $180^{\circ} \mathrm{C}$. A similar observation was made when reactions of 7 or 9 were conducted with reduced reaction times of $24 \mathrm{~h}$ or $48 \mathrm{~h}$. While the reduced reac- 
Table 1 Hydroaminoalkylation of disubstituted alkenes with $N$-methylaniline (2)

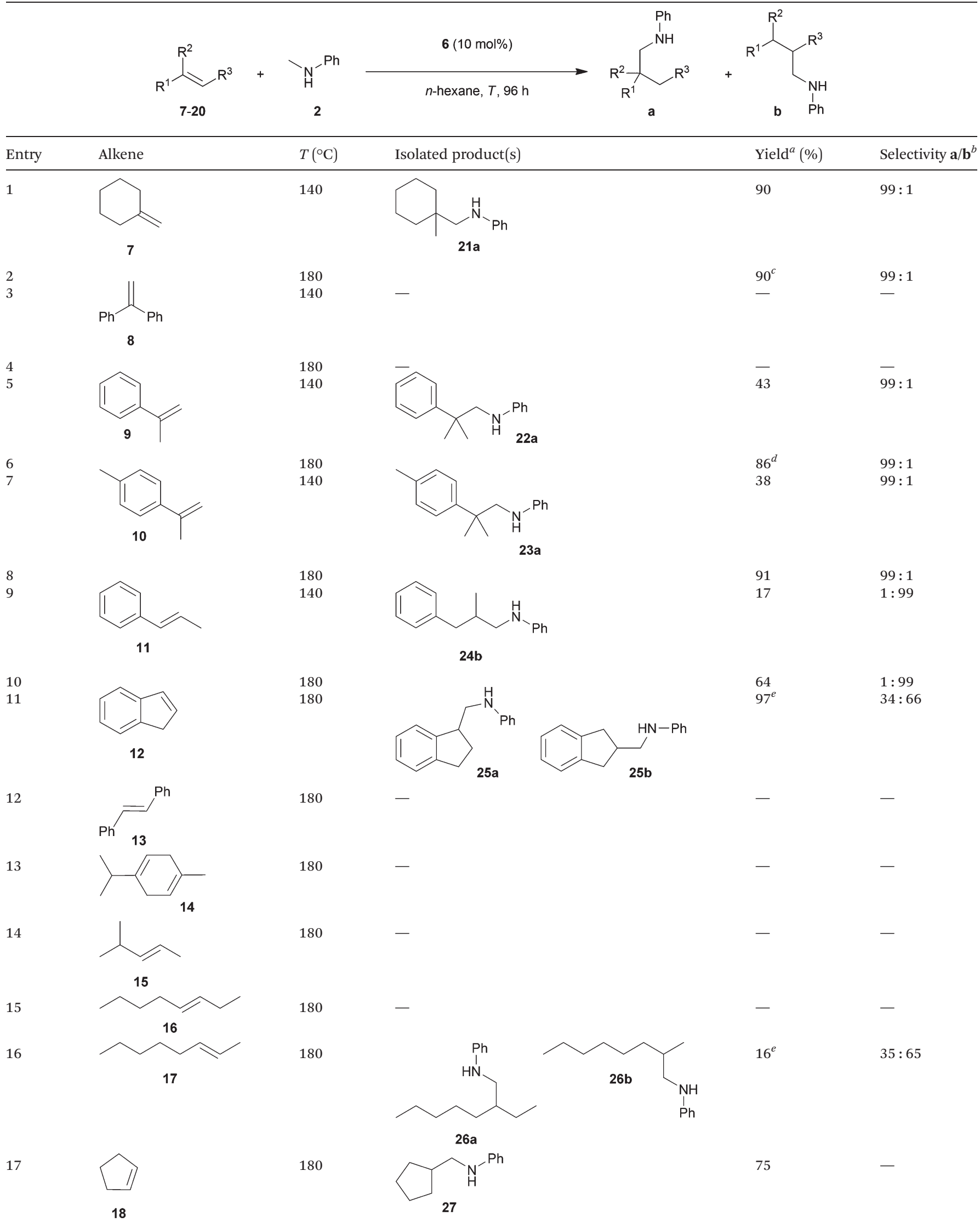


Table 1 (Contd.)

Entry

\begin{abstract}
${ }^{a}$ Reaction conditions: $N$-methylaniline $(2,2.0 \mathrm{mmol}, 214 \mathrm{mg})$, alkene $(3.0 \mathrm{mmol}), 6(109 \mathrm{mg}, 0.2 \mathrm{mmol}, 10 \mathrm{~mol} \%), n$-hexane $(1 \mathrm{~mL}), 140{ }^{\circ} \mathrm{C}$ or $180{ }^{\circ} \mathrm{C}, 96 \mathrm{~h}$, sealed Schlenk tube. Yields refer to the yield of the isolated product (a or b). ${ }^{b} \mathrm{GC}$ analysis prior to chromatography. ${ }^{c} \mathrm{~A}$ yield of $89 \%$ was obtained after a reaction time of $24 \mathrm{~h} .{ }^{d}$ Yields of $76 \%$ and $67 \%$ were obtained after reaction times of $48 \mathrm{~h}$ and $24 \mathrm{~h}$, respectively. ${ }^{e}$ The yield refers to the total yield of isolated products $(\mathbf{a}+\mathbf{b}) .{ }^{f}$ A comparable yield of $69 \%$ was obtained after a reaction time of $192 \mathrm{~h}$.
\end{abstract}

tion times did not affect the conversion of methylenecyclohexane $(7,89 \%$ yield of product $21 \mathrm{a}$ after $24 \mathrm{~h})$, corresponding reactions of $\alpha$-methylstyrene (9) gave product 22a in significantly reduced yields ( $76 \%$ after $48 \mathrm{~h}$ and $67 \%$ after $24 \mathrm{~h}$ ). As a consequence, we performed all additional experiments with a reaction time of $96 \mathrm{~h}$. To the best of our knowledge, the results obtained with styrenes $\mathbf{9}$ and $\mathbf{1 0}$ represent the first successful examples of group 4 metal-catalyzed hydroaminoalkylation reactions of $\alpha$-substituted styrene derivatives. In addition, it is worth to mention that only two examples of a corresponding reaction catalyzed by a group 5 metal catalyst have been described in the literature ${ }^{5 k, m}$ and in this case, the yield was only modest (61\%). An additional finding that underlines the high catalytic activity of $\mathbf{6}$ is the fact that with this catalyst, it was even possible to react the 1,2-disubstituted substrate $(E)$ $\beta$-methylstyrene (11) with $N$-methylaniline (2, Table 1, entries 9 and 10). Interestingly and in contrast to the reaction of $\alpha$-methylstyrene, the hydroaminoalkylation took place regioselectively at the sterically less shielded $\beta$-carbon of the double bond and correspondingly, the regioisomer $\mathbf{2 4 \mathbf { b }}$ could be isolated as the sole product of the reaction in $64 \%$ yield. Most impressively, the regioselectivity of the reaction was found to be $\mathbf{2 4 a} / \mathbf{2 4 b}=1: 99$. Previously, only two successful hydroaminoalkylations of $\beta$-substituted styrene derivatives had been achieved with a tantalum catalyst ${ }^{5 n}$ and in these cases, the regioselectivities were only modest $(1: 2.0$ and $1: 4.4)$. The well-established fact that hydroaminoalkylation product $\mathbf{2 4 \mathbf { b }}$ can be obtained from allylbenzene under much milder conditions ${ }^{5 e}$ is strongly underlined by a hydroaminoalkylation reaction between allylbenzene and $N$-methylaniline (2) performed at $140{ }^{\circ} \mathrm{C}$ in the presence of $10 \mathrm{~mol} \%$ of catalyst 6 . While under these conditions, $(E)$ - $\beta$-methylstyrene (11) gave $\mathbf{2 4 b}$ only in $17 \%$ yield (Table 1 , entry 9 ), $\mathbf{2 4 b}$ was obtained in $87 \%$ yield from allylbenzene. Interestingly, isomerization of $(E)$ - $\beta$-methyl- styrene (11) to allylbenzene during the reactions of $\mathbf{1 1}$ could not be observed by GC analysis. Additional experiments with indene (12, Table 1, entry 11) then revealed that even this challenging substrate undergoes successful hydroaminoalkylation with 2. Although the reaction delivered the two regioisomers 25a and 25b in $97 \%$ combined yield, the regioselectivity was found to be surprisingly low $(\mathbf{2 5 a} / \mathbf{2 5 b}=34: 66)$. However, as can be seen from Table 1, entries $12-15$, sterically more demanding internal alkenes like 13-16 failed to react in the presence of catalyst $\mathbf{6}$. On the other hand, it was possible to convert (E)-2-octene (17) to a mixture of the corresponding hydroaminoalkylation products $26 \mathbf{a}$ and $\mathbf{2 6 \mathbf { b }}$ (Table 1, entry 16) but in this case, the yield and the regioselectivity of the reaction turned out to be poor. In contrast to the disappointing behavior of the 1,2-dialkyl-substituted (E)-alkenes 15-17, the (Z)double bond-containing substrates cyclopentene (18) and cyclohexene (19) gave access to the corresponding hydroaminoalkylation products $\mathbf{2 7}$ and $\mathbf{2 8}$ in reasonable yields of $75 \%$ and $72 \%$, respectively (Table 1 , entries 17 and 18). In this context, it can be noted that additional alkyl-substituted cyclohexenes like 4-methyl- or 3-methylcyclohexene also underwent high-yielding hydroaminoalkylation reactions with 2 but unfortunately, formation of four inseparable regio- and diastereomers was observed in both reactions. As the result, all attempts on a precise structure assignment of the isomers failed so far. With regard to catalyst stability it can be stated that longer reaction times do not necessarily lead to improved yields. For example, reactions of cylohexene (19) with $N$-methylaniline (2) gave comparable yields of product 28 after $96 \mathrm{~h}$ (72\%, Table 1, entry 18) and $192 \mathrm{~h}(69 \%)$. Interestingly, the additional double bond present in 1,4-cyclohexadiene (20) seems to facilitate the hydroaminoalkylation reaction and as a consequence, an excellent yield of $93 \%$ of product 29 was obtained in this case (Table 1, entry 19). The remarkable fact 


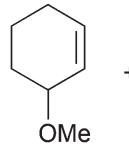

30

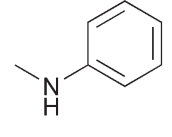

2

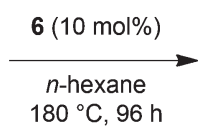

$180^{\circ} \mathrm{C}, 96 \mathrm{~h}$
Scheme 3 Intermolecular reaction of 3-methoxycyclohexene (30) with $N$-methylaniline (2) catalyzed by titanium mono(formamidinate) complex 6 .

that only the monoalkylated product 29 could be isolated from the reaction mixture is in good agreement with results from Schafer et al. ${ }^{5 n}$ and the remaining double bond offers a promising chance for further functionalization. Finally, 3-bromocyclohexene turned out to be unreactive under the reaction conditions while 3-methoxycyclohexene (30) underwent a nucleophilic substitution reaction that delivered the tertiary amine 31 in $61 \%$ yield (Scheme 3). The assumption that the latter process does not require the presence of a titanium catalyst is strongly supported by the fact that product $\mathbf{3 1}$ could also be isolated in comparable yield (58\%) from a control experiment performed in the absence of 6 .

Encouraged by the promising results obtained with $N$-methylaniline (2) we next turned our attention towards hydroaminoalkylation reactions of $\alpha$ - and $(E)$ - $\beta$-methylstyrene with various other secondary amines (Table 2 ). The unsymmetrically substituted styrenes were chosen as substrates to get further information about the regioselectivity of the hydroaminoalkylation. Initial reactions of $\alpha$-methylstyrene (9) with the donor- and acceptor-substituted $N$-methylanilines 32-34 (Table 2, entries 1-3) performed at $180{ }^{\circ} \mathrm{C}$ in the presence of $10 \mathrm{~mol} \% \mathbf{6}$ showed that both classes of substituents are generally tolerated and the para-substituents do not affect the regioselectivity of the hydroaminoalkylation. In all cases, the regioselectivity was determined to be 99:1 in favor of the branched product a which is formed by hydroaminoalkylation at the sterically more hindered $\alpha$-carbon of 9. On the other hand, the nature of the substituent on the benzene ring of the $N$-methylaniline seems to influence the efficiency of the reaction significantly. For example, $N$-methylaniline 33 bearing an electron-withdrawing para-fluoro substituent on the benzene ring gave the hydroaminoalkylation product 40a in $98 \%$ yield (Table 2, entry 2) while the corresponding donor-substituted substrate para-phenoxy- $N$-methylaniline (34) delivered the corresponding product 41a only in significantly reduced yield of $67 \%$ (Table 2, entry 3). This trend in reactivity is further supported by the observation that para-methyl- $N$-methylaniline (32) with its weak electron-donating methyl substituent gave the hydroaminoalkylation product 39 a in $88 \%$ yield (Table 2 , entry 1) which is comparable to the result obtained with $N$-methylaniline (2, 86\%, Table 1, entry 6). The well-established fact that the efficiency of titanium-catalyzed hydroaminoalkylation reactions of alkenes is strongly influenced by the steric bulk of the amine ${ }^{7 b, d, i}$ is in good agreement with our observation that the sterically more demanding amines $N$-benzylaniline (35, Table 2, entry 4), $N$-ethylaniline, $N$-propylaniline, 1,2,3,4-tetrahydroquinoline, and ortho-methyl- $N$-methylaniline failed to react with $\alpha$-methylstyrene (9) in the presence of catalyst 6. On the other hand, the dialkylamines $N$-methylcylohexylamine (36) and $N$-methylhexylamine (37) (Table 2, entries 5 and 6) were found to undergo highly regioselective hydroaminoalkylation with 9 under identical reaction conditions. Unfortunately, the branched products which were always formed with excellent regioselectivity $(\mathbf{a} / \mathbf{b}=99: 1)$ could only be obtained in modest to poor yields (14-49\%) after derivatization as the corresponding para-toluenesulfonamides 42a and 43a. The observation that both reactions took place at the methyl group of the amines exclusively is in good agreement with results obtained before with $N$-methylcylohexylamine (36) and $N$-methylhexylamine (37). ${ }^{5 e j, k, n, n, 7 f, g, i}$ Finally, it must be noted that no successful alkylation of $N$-methylbenzylamine (38, Table 2, entry 7) could be achieved with $\alpha$-methylstyrene (9). Additional hydroaminoalkylation reactions performed with $(E)-\beta$-methylstyrene (11, Table 2, entries 8-14) then revealed that $\mathbf{1 1}$ is significantly less reactive than $\alpha$-methylstyrene (9) and as a result, the corresponding hydroaminoalkylation products could only be obtained in modest to poor yields (14-65\%). However, the trend in reactivity observed with the $N$-methylanilines 32-34 (Table 2, entries 8-10) is in good agreement with the results obtained with $\alpha$-methylstyrene $(\mathbf{9}$, Table 2, entries 1-3). Again, the para-fluoro-substituted aniline 33 gave the best result (65\% yield) while the electron-donating para-phenoxy substituent present in $\mathbf{3 4}$ caused a severe drop in yield (14\%). Among the dialkylamines 36-38 (Table 2, entries 12-14), again only $N$-methylcylohexylamine (36) and $N$-methylhexylamine (37) reacted successfully with $\mathbf{1 1}$ and in these cases, the products could be isolated after derivatization as the corresponding para-toluenesulfonamides $\mathbf{4 7} \mathbf{b}$ and $\mathbf{4 8 b}$ in $38 \%$ and $41 \%$ yield, respectively. On the other hand, no reaction could be achieved with $N$-methylbenzylamine (38) and the sterically more demanding substrate $N$-benzylaniline (35, Table 2, entries 11 and 14). However, as described above (Table 1, entry 9), all successful hydroaminoalkylation reactions of $(E)-\beta$-methylstyrene (11) took place with excellent regioselectivities $(\geq 98: 2)$ at the sterically less hindered $\beta$-carbon of $\mathbf{1 1}$ giving access to 3-phenylpropylamine derivatives.

Owing to the electronic similarities between styrenes and conjugated dienes, we next turned our attention towards hydroaminoalkylation reactions of substituted 1,3-butadienes. Corresponding reactions are extremely rare in the literature ${ }^{4,7 h, i}$ and so far, $\operatorname{Ind}_{2} \mathrm{TiMe}_{2}$ (Ind $=\eta^{5}$-indenyl) ${ }^{7 h}$ and aminopyridinato titanium complex $5^{7 i}$ represent the only suitable early transition metal catalysts for the intermolecular hydroaminoalkylation of 1-aryl- and 1-alkyl-substituted 1,3-butadienes. Unfortunately, the titanium-catalyzed reaction is limited to selected $N$-methylanilines and the efficiency of the reaction strongly depends on the substituents bound to the 1,3-diene or the benzene ring of the $N$-methylaniline. For example, reactions performed with the chloro-substituted substrates parachloro- $N$-methylaniline or (E)-1-(para-chlorophenyl)-1,3-butadiene gave the corresponding hydroaminoalkylation products only in poor yields $(\leq 37 \%)$ and in addition, dialkylamines or 
Table 2 Hydroaminoalkylation of $\alpha$ - and $(E)-\beta$-methylstyrene $(9,11)$ with various amines

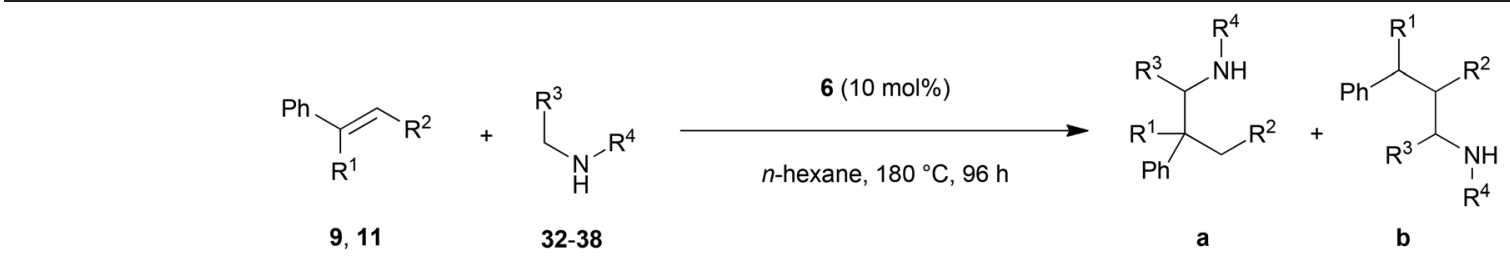

Entry $\quad$ Styrene

2<smiles>C/C=C/c1ccccc1</smiles><smiles>Cc1ccc(NCC(C)(C)c2ccccc2)cc1</smiles>

$\operatorname{Yield}^{a}(\%)$
Selectivity $\mathbf{a} / \mathbf{b}^{b}$<smiles>CC(C)(CNc1ccc(F)cc1)c1ccccc1</smiles><smiles>CC(C)(CNc1ccc(Oc2ccccc2)cc1)c1ccccc1</smiles>

67

$99: 1$

4

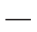

5<smiles>CN(CC(C)(C)c1ccccc1)C1CCCCC1</smiles>

$14^{c, d}$

$99: 1$

6<smiles>CCCCCCN([As])CC(C)(C)c1ccccc1</smiles>

$49^{c, d}$

$99: 1$

7

8

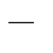<smiles>Cc1ccc(NCC(C)Cc2ccccc2)cc1</smiles>

31

$1: 99$

9<smiles>CNc1ccc(F)cc1</smiles>

10<smiles>CNc1ccc(Oc2ccccc2)cc1</smiles>

11<smiles>c1ccc(CNc2ccccc2)cc1</smiles>

12<smiles>CNC1CCCCC1</smiles><smiles>CC(Cc1ccccc1)CN([AlH2])C1CCCCC1</smiles>

$38^{c, d}$

$1: 99$

65

$2: 98$

14

$1: 99$

$\mathrm{Ph}$

$-$

$47 b$ 
Table 2 (Contd.)

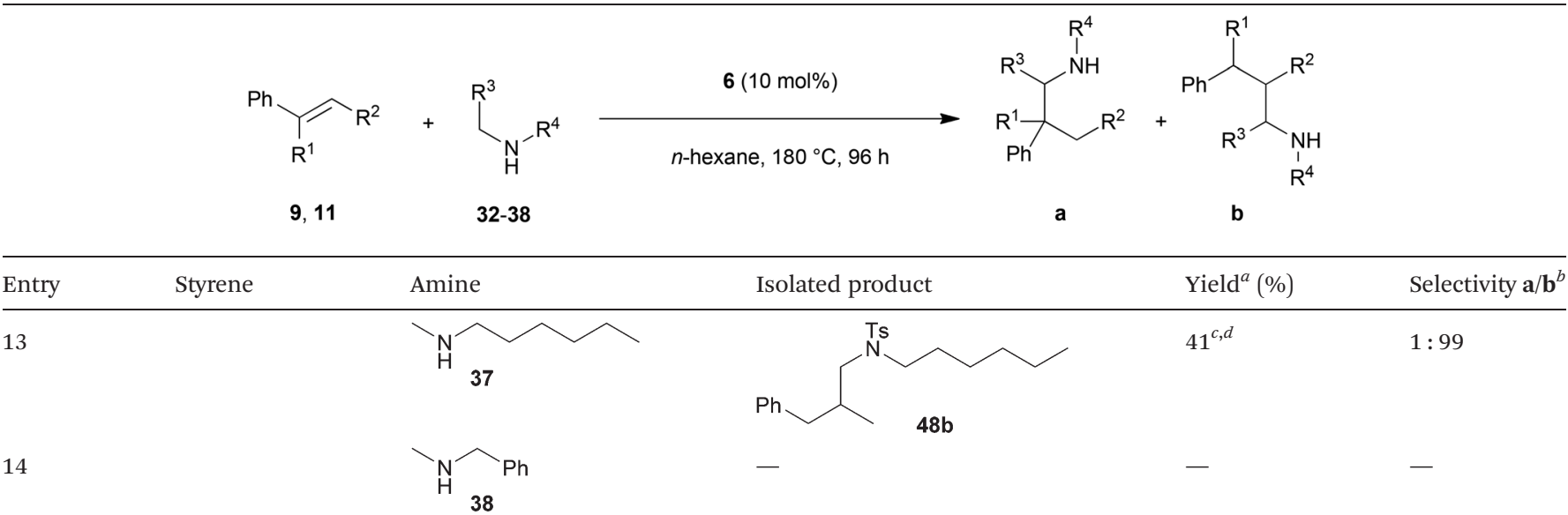

\begin{abstract}
${ }^{a}$ Reaction conditions: amine $(2.0 \mathrm{mmol})$, alkene $(3.0 \mathrm{mmol}), 6(109 \mathrm{mg}, 0.2 \mathrm{mmol}, 10 \mathrm{~mol} \%), n$-hexane $(1 \mathrm{~mL}), 180{ }^{\circ} \mathrm{C}, 96 \mathrm{~h}$, sealed Schlenk tube. Yields refer to the yield of the isolated product $(\mathbf{a}$ or $\mathbf{b}) .{ }^{b} \mathrm{GC}$ analysis prior to chromatography. ${ }^{c}$ The product was isolated after derivatization as the corresponding para-toluenesulfonamide. ${ }^{d}$ The reaction took place at the methyl group of the amine exclusively.
\end{abstract}

$N$-alkylanilines bearing alkyl groups larger than a methyl group did not react at all in the presence of $\operatorname{Ind}_{2} \mathrm{TiMe}_{2}$. Initial hydroaminoalkylation reactions of $(E)$-1-phenyl-1,3-butadiene (49) with various para-substituted $N$-methylanilines were performed in the presence of $10 \mathrm{~mol} \% 6$ at $120{ }^{\circ} \mathrm{C}$. The relatively low reaction temperature was chosen because it has already been observed that dimerization of the 1,3-butadiene by DielsAlder cycloaddition becomes a yield-reducing side reaction at temperatures above $130{ }^{\circ} \mathrm{C} .^{7 h}$ As can be seen from Table 3, entries 1-7, successful hydroaminoalkylation could be achieved with electron donor- $(\mathbf{3 4}, \mathbf{5 5 - 5 8})$ and electron accep- tor-substituted $N$-methylanilines (59) and in all cases, only the terminal double bond of the diene reacted. Owing to their better separation from other nitrogen-containing molecules in the reaction mixture, the hydroaminoalkylation products were isolated after conversion into their corresponding acetamides (AcCl, $\mathrm{NEt}_{3}, \mathrm{CH}_{2} \mathrm{Cl}_{2}, \mathrm{rt}$ ). Although the products $60-66 \mathrm{a} / \mathbf{b}$ could be obtained with good to modest yields (45-82\%), the regioselectivity of the hydroaminoalkylation was always close to $1: 1$ which is worse compared to typical regioselectivities obtained with the catalysts 5 or $\operatorname{Ind}_{2} \mathrm{TiMe}_{2}$. With the latter catalyst, formation of the branched regioisomer was usually favored and

Table 3 Hydroaminoalkylation of 1,3-dienes with $N$-methylanilines

\begin{tabular}{|c|c|c|c|c|c|c|c|c|}
\hline \multicolumn{2}{|c|}{$49-54$} & $2,34,55-59$ & \multicolumn{2}{|c|}{$\begin{array}{c}\text { 1) } 6(10 \mathrm{~mol} \%) \\
\text { n-hexane, } 120^{\circ} \mathrm{C}, 48 \mathrm{~h} \\
\text { 2) } \mathrm{AcCl}, \mathrm{NEt}_{3}, \mathrm{CH}_{2} \mathrm{Cl}_{2} \\
25^{\circ} \mathrm{C}, 16 \mathrm{~h}\end{array}$} & a & \multicolumn{2}{|r|}{ b } & \\
\hline Entry & Diene & $\mathrm{R}^{1}$ & $\mathrm{R}^{2}$ & Amine & $\mathrm{R}^{3}$ & Products & Yield $^{a}(\%)$ & Selectivity $\mathbf{a} / \mathbf{b}^{b}$ \\
\hline 1 & 49 & $\mathrm{Ph}$ & $\mathrm{H}$ & 2 & $\mathrm{H}$ & $60 a / b$ & 73 & $55: 45$ \\
\hline 2 & 49 & $\mathrm{Ph}$ & $\mathrm{H}$ & 34 & $p$-OPh & $61 a / b$ & 45 & $54: 46$ \\
\hline 3 & 49 & $\mathrm{Ph}$ & $\mathrm{H}$ & 55 & $p$-OMe & $62 a / b$ & 46 & $54: 46$ \\
\hline 4 & 49 & $\mathrm{Ph}$ & $\mathrm{H}$ & 56 & $p-\mathrm{OCF}_{3}$ & $63 a / b$ & 82 & $53: 47$ \\
\hline 5 & 49 & $\mathrm{Ph}$ & $\mathrm{H}$ & 57 & $p$-SMe & $64 a / b$ & 53 & $54: 46$ \\
\hline 6 & 49 & $\mathrm{Ph}$ & $\mathrm{H}$ & 58 & $p$-iso-Pr & $65 a / b$ & 64 & $53: 47$ \\
\hline 7 & 49 & $\mathrm{Ph}$ & $\mathrm{H}$ & 59 & $p-\mathrm{Cl}$ & $66 a / b$ & 65 & $50: 50$ \\
\hline 8 & 50 & $p-\mathrm{Cl}-\mathrm{C}_{6} \mathrm{H}_{4}$ & $\mathrm{H}$ & 2 & $\mathrm{H}$ & $67 a / b$ & 52 & $50: 50$ \\
\hline 9 & 51 & $p-\mathrm{F}-\mathrm{C}_{6} \mathrm{H}_{4}$ & $\mathrm{H}$ & 2 & $\mathrm{H}$ & $68 a / b$ & 53 & $50: 50$ \\
\hline 10 & 52 & $n-\mathrm{C}_{6} \mathrm{H}_{13}$ & $\mathrm{H}$ & 2 & $\mathrm{H}$ & $69 a / b$ & $68^{c}$ & $50: 27: 23^{d}$ \\
\hline 11 & 53 & $\mathrm{C}_{6} \mathrm{H}_{5}-\left(\mathrm{CH}_{2}\right)_{2}$ & $\mathrm{H}$ & 2 & $\mathrm{H}$ & $70 \mathbf{a} / \mathbf{b}^{e}$ & $87^{e}$ & $47: 28: 25^{d}$ \\
\hline 12 & 54 & $\mathrm{Ph}$ & $\mathrm{CH}_{3}$ & 2 & $\mathrm{H}$ & $71 a / b$ & 73 & $51: 49$ \\
\hline
\end{tabular}

${ }^{a}$ Reaction conditions: (1) amine $(2.0 \mathrm{mmol})$, diene ( $\left.3.0 \mathrm{mmol}\right), 6(109 \mathrm{mg}, 0.2 \mathrm{mmol}, 10 \mathrm{~mol} \%), n$-hexane $(1 \mathrm{~mL}), 120{ }^{\circ} \mathrm{C}, 48 \mathrm{~h}, \mathrm{sealed} \mathrm{Schlenk}$ tube; (2) acetyl chloride $\left(1 \mathrm{M}\right.$ in $\left.\mathrm{CH}_{2} \mathrm{Cl}_{2}, 4.0 \mathrm{mmol}\right), \mathrm{NEt}_{3}(4.0 \mathrm{mmol}), \mathrm{CH}_{2} \mathrm{Cl}_{2}(30 \mathrm{~mL}), 25{ }^{\circ} \mathrm{C}, 16$ h. Yields refer to the total yield of isolated products $(\mathbf{a}+\mathbf{b}) \cdot{ }^{b} \mathrm{GC}$ analysis prior to acetylation and chromatography. ${ }^{c}$ The reaction was carried out on a 4 mmol scale. ${ }^{d}$ Formation of an additional branched product with an isomerized double bond was observed. The selectivity is given as branched (a)/branched isomerized/linear (b). For details, see the experimental section. ${ }^{e}$ Directly isolated as the corresponding amine (without acetylation). 
selectivities between $2: 1$ and $3: 1^{7 h}$ could be achieved while 5 produced linear regioisomers almost exclusively. ${ }^{7 i}$ In this context, it should be noted that separation of the regioisomers is possible by chromatography. On the other hand, it is worth mentioning that with several substrates significantly improved yields were obtained with the new catalyst 6 . For example, para-chloro- $N$-methylaniline (59) gave a mixture of the corresponding products 66a and 66 in $65 \%$ combined yield (Table 3, entry 7) while the corresponding reaction performed with Ind $_{2} \mathrm{TiMe}_{2}$ gave the same products only in $6 \%$ yield. ${ }^{7 h}$ In addition, a significantly improved yield ( $46 \%$ versus $23 \%^{7 h}$ ) was obtained with para-methoxy- $N$-methylaniline (55) and it was also possible to perform the hydroaminoalkylation with para-trifluoromethoxy- $N$-methylaniline (56, Table 3, entry 4). Amine 56 represents a highly promising substrate because the para-trifluoromethoxy group is often present in synthetic agrochemicals and pharmaceuticals. ${ }^{9}$ Impressively, even para-thiomethyl- $N$-methylaniline (57) which does not undergo hydroaminoalkylation with 49 in the presence of $\operatorname{Ind}_{2} \mathrm{TiMe}_{2}$ did react in the presence of catalyst 6 (Table 3, entry 5). Additional reactions between $N$-methylaniline (2) and 1,3-butadienes 50-54 (Table 3, entries 8-12) delivered mixtures of the branched and the linear hydroaminoalkylation products $67-71 \mathrm{a} / \mathrm{b}$ in good to modest yields but again, only with poor regioselectivities. In this context, it must be mentioned that a third product was formed during reactions of the 1-alkyl-substituted dienes $(E)$-1,3-decadiene (52) and (E)-6-phenyl-1,3-hexadiene (53, Table 3, entries 10 and 11). These additionally formed products were identified to be branched hydroaminoalkylation products with an isomerized double bond. The formation of two branched isomeric olefins from $\mathbf{2}$ and $\mathbf{5 2}$ was confirmed by hydrogenation of a mixture of $69 \mathbf{a}$ and its isomer with $\mathrm{Pd} / \mathrm{C}$ which gave the corresponding saturated compound $N$-phenyl- $N$-(2-methyldecyl)acetamide (72) as the sole hydrogenation product in $85 \%$ yield. On the other hand, formation of additional linear hydroaminoalkylation products with isomerized double bond was not observed in the presence of catalyst 6. This is in sharp contrast to the finding that linear products with isomerized double bond are formed during hydroaminoalkylation reactions of 1,3-butadienes catalyzed by aminopyridinato titanium catalyst $5 .^{7 i}$ Finally, it was found that even the 1,2-disubstituted 1,3-diene $\mathbf{5 4}$ undergoes successful hydroaminoalkylation with 2 . The corresponding products 71a and 71b were obtained in $73 \%$ combined yield and the regioselectivity was determined to be $51: 49$ (Table 3 , entry 12). In this context, it is worth mentioning that $\mathbf{5 4}$ and $\mathbf{2}$ are exclusively converted into the branched hydroaminoalkylation product with the catalyst $\mathrm{Ind}_{2} \mathrm{TiMe}_{2}$.

Because hydroaminoalkylation reactions of styrenes with $N$-alkylanilines catalyzed by aminopyridinato complex $\mathbf{4}$ have already revealed that the regioselectivity in favor of the linear product increases with increasing size of the $N$-alkyl substituent, $^{7 g}$ we additionally tried to react $(E)$-1-phenyl-1,3-butadiene (49) with the sterically more demanding amines $N$ benzylaniline (35), $N$-methylcylohexylamine (36), $N$-methylhexylamine (37), and $N$-methylbenzylamine (38). All reactions were performed with $10 \mathrm{~mol} \% 6$ in $n$-hexane at $120{ }^{\circ} \mathrm{C}$ in sealed Schlenk tubes and after $48 \mathrm{~h}$, the reaction mixtures were analyzed by GC. During this study, it was found that among the four amines, only $N$-methylbenzylamine (38) underwent successful hydroaminoalkylation with $\mathbf{4 9}$ in the presence of catalyst 6 (Table 4, entry 1). Interestingly and in good agreement with the behavior of aminopyridinato catalyst 4, a high regioselectivity of $93: 7$ in favor of the linear hydroaminoalkylation product was observed and after conversion into the corresponding para-toluenesulfonamide and purification by chromatography, the linear product $\mathbf{7 6} \mathrm{b}$ was isolated in $58 \%$ yield. Due to the high regioselectivity of the reaction, the branched product could not be isolated but the NMR spectra of $\mathbf{7 6 b}$ showed very weak signal sets, which could be assigned to trace impurities of the branched product. In this context, it must also be mentioned that the isolated material additionally contained minor amounts of tosylated $N$-methylbenzylamine formed from unreacted amine 38. Interestingly and in contrast to the reactions of $N$-methylcylohexylamine (36) and $N$-methylhexylamine (37) with $\alpha$ - and (E)- $\beta$-methylstyrene (9 and 11, Table 2, entries 5, 6, 12 and 13), alkylation of 38 occurred at the benzyl position of the amine exclusively. However, this observation is in good agreement with the fact that group $4^{7 g, i}$ and $5^{5 e}$ metal-catalyzed hydroaminoalkylation reactions of sterically less demanding mono-substituted alkenes and styrenes performed with $\mathbf{3 8}$ usually take place selectively at the benzyl position of 38. Selective alkylation at the methyl group of $N$-methylbenzylamine (38) has only been achieved with vinylcyclohexane in the presence of tantalum and niobium binaphtholate catalysts developed by the Hultzsch group. ${ }^{5 h, i}$ With these results in hand, we finally used the para-substituted 1-phenyl-1,3-butadienes $\mathbf{5 0 ,} \mathbf{5 1}$, and $\mathbf{7 3}$ as well as the ortho-substituted dienes $\mathbf{7 4}$ and $\mathbf{7 5}$ for hydroaminoalkylation reactions with amine 38 (Table 4, entries 2-6). The results obtained with these substrates clearly prove that electron-withdrawing chloro or fluoro substituents (Table 4, entries 2 and 3) and electron-donating methyl or methoxy groups (Table 4, entries 4-6) as well as ortho-substitution of the phenyl ring (Table 4, entries 5 and 6) are tolerated with no significant impact on the yield $(60-71 \%)$ and the regioselectivity (13:87-8:92) of the reaction. The latter finding is in good agreement with the remote position of the phenyl substituent relative to the reacting double bond of the diene. ${ }^{7 h}$ However, in all cases, again only the linear hydroaminoalkylation products $\mathbf{7 7 - 8 1 b}$ could be isolated from the reaction mixtures and the branched products were only detected by GC or as trace impurities in the NMR spectra of the isolated linear products. In this context, it is worth mentioning that corresponding $\delta$-alkenylamine derivatives are promising substrates for the synthesis of cis- $N$-methyl-2,5-disubstituted pyrrolidines. ${ }^{10}$ Although Table 4 summarizes the first successful examples of hydroaminoalkylation reactions of conjugated dienes with $N$-methylbenzylamine (38), complex 6 unfortunately failed to catalyze a number of closely related reactions. For example, 1-phenyl-substituted 1,3-butadienes bearing additional methyl or chloro substituents in the 2-position of the diene system 


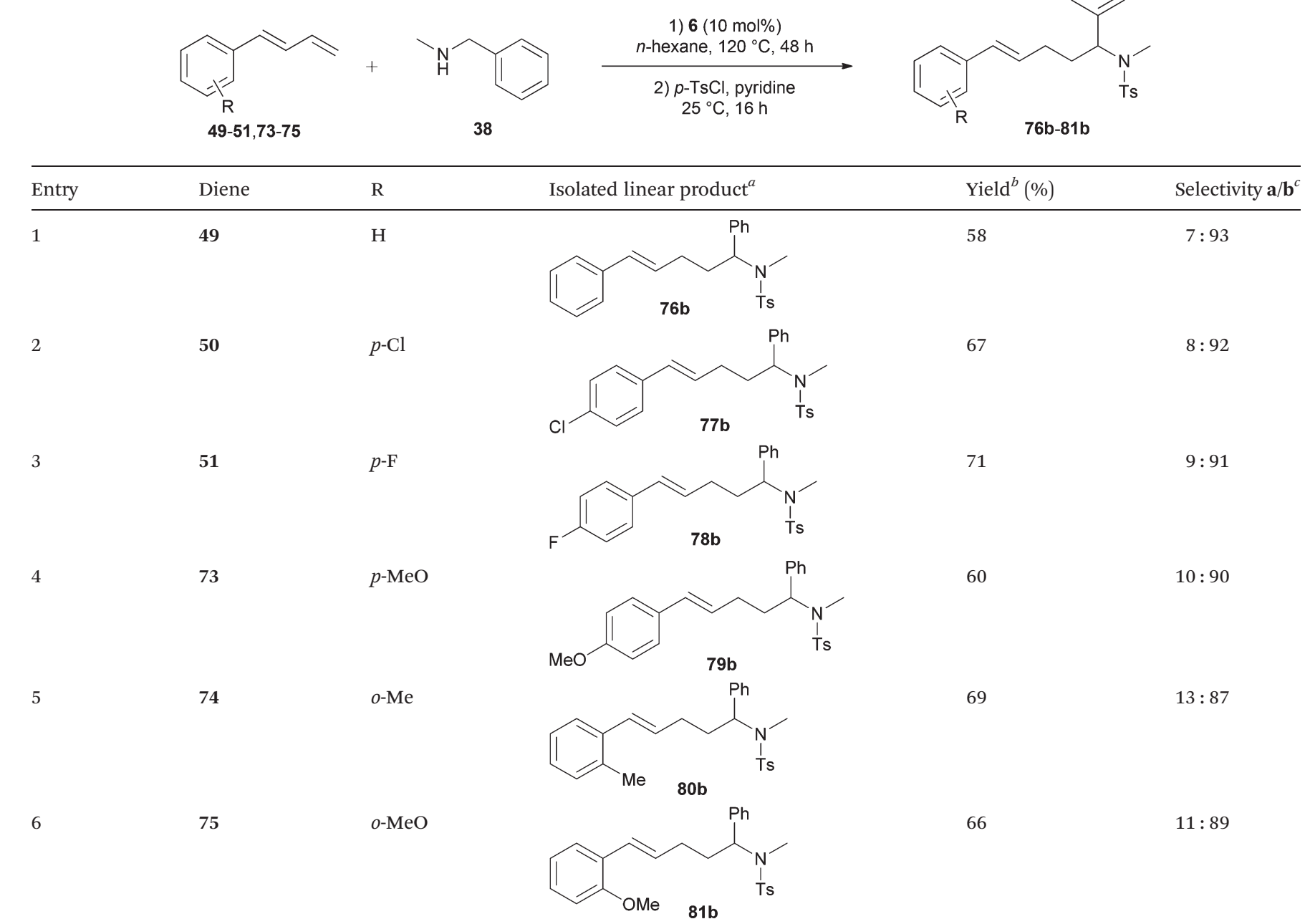

${ }^{a}$ Only the isolated, linear product is presented. ${ }^{b}$ Reaction conditions: (1) $\mathrm{N}$-methylbenzylamine (38, $\left.242 \mathrm{mg}, 2.0 \mathrm{mmol}\right)$, diene (3.0 mmol), 6 (109 mg, $0.2 \mathrm{mmol}, 10 \mathrm{~mol} \%), n$-hexane $(1 \mathrm{~mL}), 120^{\circ} \mathrm{C}, 48 \mathrm{~h}$, sealed Schlenk tube; (2) para-toluenesulfonyl chloride (763 mg, $\left.4.0 \mathrm{mmol}\right)$, pyridine $(10 \mathrm{~mL}), 25^{\circ} \mathrm{C}, 16 \mathrm{~h}$. Yields refer to the yield of the isolated linear product (b). ${ }^{C} \mathrm{GC}$ analysis prior to tosylation and chromatography.

did not undergo the reaction and the 1-alkyl-substituted 1,3butadiene 52 delivered only trace amounts of the expected hydroaminoalkylation products which could only be detected and characterized by GC/MS analysis. In addition, even a small variation of the $N$-methylbenzylamine motif resulted in a lack of reactivity. Neither $\mathrm{N}$-ethyl-, $\mathrm{N}$-iso-propyl-, $\mathrm{N}$-cyclohexyl-, $N$-benzyl-, nor $N$-(2-phenylethyl)-substituted benzylamines underwent successful hydroaminoalkylation with $(E)$-1-phenyl1,3-butadiene (49) in the presence of catalyst 6.

\section{Conclusions}

In summary, we have shown that the easily accessible titanium mono(formamidinate) complex $6^{8 a}$ which bears 2,6-diisopropylphenyl groups as the amidinate $\mathrm{N}$-substituents is a highly active catalyst for the regioselective intermolecular hydroami- noalkylation of unactivated, sterically demanding 1,1- and 1,2disubstituted alkenes and styrenes with secondary amines. While corresponding reactions of 1,1-disubstituted alkenes and styrenes give access to the branched hydroaminoalkylation products exclusively, $(E)-\beta$-methylstyrene selectively reacts at the sterically less hindered $\beta$-carbon. In addition, with catalyst 6, it is also possible for the first time to convert 1-phenyl-substituted $(E)$-1,3-butadienes and $N$-methylbenzylamine into $\delta$-alkenylamine derivatives.

\section{Experimental}

\section{General information}

All reactions were performed under an inert atmosphere of nitrogen in oven-dried Schlenk tubes (Duran glassware, $100 \mathrm{~mL}, \varnothing=30 \mathrm{~mm}$ ) equipped with Teflon stopcocks and mag- 
netic stirring bars $(15 \times 4.5 \mathrm{~mm})$. Prior to use, all alkenes, styrenes, and amines were distilled and degassed. $n$-Hexane was purified by distillation from sodium wire and degassed. The alkenes, styrenes, amines, and $n$-hexane were stored in a nitrogen-filled glove box. Catalyst $6^{8 a}$ and the dienes ${ }^{7 h, i}$ were synthesized according to literature procedures and stored in a nitrogen-filled glove box. All other chemicals were purchased from commercial sources and were used without further purification. Unless otherwise noted, the ratio of regioisomers was determined by gas chromatography prior to flash column chromatography. For thin layer chromatography, silica on TLC aluminium foils with fluorescent indicator $254 \mathrm{~nm}$ was used. The substances were detected with UV light and/or iodine. For flash column chromatography, silica gel (particle size 0.037-0.063 mm) was used. Light petroleum ether (b.p. $\left.40-60{ }^{\circ} \mathrm{C}, \mathrm{PE}\right)$, tert-butyl methyl ether (MTBE) and ethyl acetate (EtOAc) used for chromatography were distilled via Raschig columns at ambient pressure. Other solvents used for chromatography were distilled prior to use. All products that have already been reported in the literature were identified by comparison of the obtained ${ }^{1} \mathrm{H}$ NMR and ${ }^{13} \mathrm{C}$ NMR spectra with those reported in the literature. New compounds were additionally characterized by infrared spectroscopy, mass spectrometry, and high resolution mass spectrometry (HRMS). ${ }^{1} \mathrm{H}$, ${ }^{13} \mathrm{C}$ and ${ }^{19} \mathrm{~F}$ NMR spectra were recorded at 500, 470, 300, 125 and $75 \mathrm{MHz}$. All ${ }^{1} \mathrm{H}$ NMR spectra are reported in $\delta$ units (ppm) relative to the signal of TMS at $0.00 \mathrm{ppm}$ or relative to the residual solvent signal of $\mathrm{CDCl}_{3}$ at $7.26 \mathrm{ppm}$. All ${ }^{13} \mathrm{C} \mathrm{NMR}$ spectra are reported in $\delta$ units ( $\mathrm{ppm}$ ) relative to the central line of the triplet for $\mathrm{CDCl}_{3}$ at $77.0 \mathrm{ppm}$. All ${ }^{19} \mathrm{~F}$ NMR spectra are reported in $\delta$ units (ppm) relative to the signal of $\mathrm{CFCl}_{3}$ at $0.00 \mathrm{ppm}$. Infrared spectra were recorded either via $\mathrm{KBr}$ pellets or on an ATR spectrometer. Mass spectra and high resolution mass spectra (HRMS) were recorded either in EI (with an ionization potential of $70 \mathrm{eV}$ ) or in ESI mode (ESI, TOF).

\section{General procedure A for the hydroaminoalkylation of disubstituted alkenes and styrenes with $\mathrm{N}$-substituted arylamines (Tables 1 and 2)}

An oven dried Schlenk tube equipped with a Teflon stopcock and a magnetic stirring bar was transferred into a nitrogenfilled glovebox and charged with complex 6 (109 mg, $0.2 \mathrm{mmol}, 10 \mathrm{~mol} \%)$ and $n$-hexane $(0.5 \mathrm{~mL})$. Afterwards the $\mathrm{N}$-substituted arylamine $(2.0 \mathrm{mmol})$, the alkene or styrene $(3.0 \mathrm{mmol})$, and $n$-hexane $(0.5 \mathrm{~mL})$ were added. After heating the mixture to $180{ }^{\circ} \mathrm{C}$ for $96 \mathrm{~h}$, the mixture was cooled to room temperature and dichloromethane $(40 \mathrm{~mL})$ was added. Then the regioselectivity of the reaction was determined by GC (if applicable) and finally, the crude product was purified by flash column chromatography $\left(\mathrm{SiO}_{2}\right)$.

\section{General procedure B for the hydroaminoalkylation of disubstituted styrenes with dialkylamines (Table 2)}

An oven dried Schlenk tube equipped with a Teflon stopcock and a magnetic stirring bar was transferred into a nitrogenfilled glovebox and charged with complex 6 (109 mg,
$0.2 \mathrm{mmol}, 10 \mathrm{~mol} \%)$ and $n$-hexane $(0.5 \mathrm{~mL})$. Afterwards the dialkylamine $(2.0 \mathrm{mmol})$, the styrene $(3.0 \mathrm{mmol})$, and $n$-hexane $(0.5 \mathrm{~mL})$ were added. After heating the mixture to $180{ }^{\circ} \mathrm{C}$ for $96 \mathrm{~h}$, the crude product was transferred to a $100 \mathrm{~mL}$ round-bottomed flask and the Schlenk tube was rinsed with dichloromethane $(4 \times 10 \mathrm{~mL})$. The regioselectivity of the reaction was determined by GC and subsequently, the combined solutions were concentrated under vacuum to a total volume of $10 \mathrm{~mL}$. The resulting mixture was then treated with $2 \mathrm{~N}$ aqueous $\mathrm{NaOH}(5 \mathrm{~mL}, 10.0 \mathrm{mmol})$ and para-toluenesulfonyl chloride (572 mg, $3.0 \mathrm{mmol}$ ). The resulting biphasic mixture was stirred vigorously at room temperature for $20 \mathrm{~h}$ before the solution was partitioned between dichloromethane $(50 \mathrm{~mL})$ and water $(20 \mathrm{~mL})$. The formed layers were separated, the aqueous one was extracted with dichloromethane $(3 \times 10 \mathrm{~mL})$ and the combined organic layers were dried with $\mathrm{MgSO}_{4}$. After concentration under vacuum, the product was isolated by flash column chromatography $\left(\mathrm{SiO}_{2}\right)$.

\section{General procedure $\mathrm{C}$ for the hydroaminoalkylation of 1,3-dienes with $N$-methylanilines (Table 3)}

An oven dried Schlenk tube equipped with a Teflon stopcock and a magnetic stirring bar was transferred into a nitrogenfilled glovebox and charged with 6 (109 $\mathrm{mg}, 0.20 \mathrm{mmol}$, $10 \mathrm{~mol} \%)$, the diene $(3.0 \mathrm{mmol})$, the amine $(2.0 \mathrm{mmol})$, and $n$-hexane $(1 \mathrm{~mL})$. Then the tube was sealed and the resulting mixture was heated to $120{ }^{\circ} \mathrm{C}$ for $48 \mathrm{~h}$. After the mixture had been cooled to room temperature, tert-butyl methyl ether $(30 \mathrm{~mL})$ was added and the regioselectivity of the reaction was determined by GC. To achieve a better separation of the products from remaining $N$-methylanilines, acetyl chloride $(1 \mathrm{M}$ in $\mathrm{CH}_{2} \mathrm{Cl}_{2}, 4 \mathrm{~mL}, 4 \mathrm{mmol}$ ), and triethylamine (405 $\mathrm{mg}$, $4 \mathrm{mmol}$ ) were added and the reaction mixture was stirred at room temperature for $16 \mathrm{~h}$. Finally, the solvent was removed in the presence of Celite ${ }^{\circledR}$ and the residue was purified by flash column chromatography $\left(\mathrm{SiO}_{2}\right)$.

\section{General procedure $D$ for the hydroaminoalkylation of 1,3-dienes with $N$-methylbenzylamine (38, Table 4)}

An oven dried Schlenk tube equipped with a Teflon stopcock and a magnetic stirring bar was transferred into a nitrogenfilled glovebox and charged with 6 (109 $\mathrm{mg}, 0.20 \mathrm{mmol}$, $10 \mathrm{~mol} \%)$, the diene $(3.0 \mathrm{mmol}), N$-methylbenzylamine (38, $242 \mathrm{mg}, 2.0 \mathrm{mmol})$, and $n$-hexane $(1 \mathrm{~mL})$. Then the tube was sealed and the resulting mixture was heated to $120^{\circ} \mathrm{C}$ for $48 \mathrm{~h}$. After the mixture had been cooled to room temperature, tertbutyl methyl ether $(30 \mathrm{~mL})$ was added and the regioselectivity of the reaction was determined by GC. Then the solvent was removed under reduced pressure and pyridine $(10 \mathrm{~mL})$ and para-toluenesulfonyl chloride $(763 \mathrm{mg}, 4.0 \mathrm{mmol})$ were added. After the resulting mixture had been stirred overnight at room temperature, dichloromethane $(50 \mathrm{~mL})$ was added and the organic mixture was extracted with aqueous $\mathrm{HCl}(4 \mathrm{M}, 50 \mathrm{~mL})$. Then the aqueous layer was extracted with dichloromethane $(3 \times 15 \mathrm{~mL})$ and the combined organic layers were dried with $\mathrm{MgSO}_{4}$ and concentrated under reduced pressure in the 
presence of silica gel. (Note: The use of Celite ${ }^{\circledR}$ instead of silica gel leads to significantly reduced yields.) Finally, the product was purified by flash column chromatography $\left(\mathrm{SiO}_{2}\right)$. Due to the viscosity of the products, removal of remaining solvents required storage of the products under high vacuum for several hours.

Amines $3 \mathbf{a}^{5 m}$ and $3 \mathbf{b}^{7 i}$ General procedure A was used to synthesize $3 \mathbf{a}$ and $3 \mathbf{b}$ from $N$-methylaniline $(2,214 \mathrm{mg}, 2.0 \mathrm{mmol})$ and styrene $(\mathbf{1}, 313 \mathrm{mg}, 3.0 \mathrm{mmol})$. After purification by flash chromatography (PE-EtOAc, 40:1), a mixture of $3 \mathbf{a}$ and $\mathbf{3 b}$ (406 mg, $1.92 \mathrm{mmol}, 96 \%$ ) was isolated as a yellow oil. Prior to chromatography, the ratio $3 \mathbf{a} / 3 \mathbf{b}$ was determined to be $73: 27$. For characterization, it was possible to separate the regioisomers by chromatography (PE-EtOAc, $40: 1$ ). 3a: ${ }^{1} \mathrm{H}$ NMR (300 MHz, $\left.\mathrm{CDCl}_{3}, \mathrm{TMS}\right) \delta=7.25(\mathrm{t}, J=7.3 \mathrm{~Hz}, 2 \mathrm{H}), 7.19-7.13$ (m, 3H), $7.09(\mathrm{t}, J=7.7 \mathrm{~Hz}, 2 \mathrm{H}), 6.63(\mathrm{t}, J=7.3 \mathrm{~Hz}, 1 \mathrm{H}), 6.51(\mathrm{~d}$, $J=7.8 \mathrm{~Hz}, 2 \mathrm{H}), 3.26(\mathrm{dd}, J=12.4,6.2 \mathrm{~Hz}, 1 \mathrm{H}), 3.16(\mathrm{dd}, J=$ $12.3,8.3 \mathrm{~Hz}, 1 \mathrm{H}), 2.99$ (sext, $J=7.0 \mathrm{~Hz}, 1 \mathrm{H}), 1.26$ (d, $J=7.0 \mathrm{~Hz}$, $3 \mathrm{H}) \mathrm{ppm} .{ }^{13} \mathrm{C}$ NMR $\left(125 \mathrm{MHz}, \mathrm{CDCl}_{3}\right) \delta=147.8$ (C), 144.4 (C), $129.2(\mathrm{CH}), 128.6(\mathrm{CH}), 127.2(\mathrm{CH}), 126.6(\mathrm{CH}), 117.5(\mathrm{CH})$, $113.1(\mathrm{CH}), 51.0\left(\mathrm{CH}_{2}\right), 39.1(\mathrm{CH}), 19.7\left(\mathrm{CH}_{3}\right)$ ppm. 3b: ${ }^{1} \mathrm{H}$ NMR (300 MHz, TMS) $\delta=7.34-7.24(\mathrm{~m}, 2 \mathrm{H}), 7.24-7.09$ $(\mathrm{m}, 5 \mathrm{H}), 6.69(\mathrm{t}, J=7.3 \mathrm{~Hz}, 1 \mathrm{H}), 6.57(\mathrm{~d}, J=8.1 \mathrm{~Hz}, 2 \mathrm{H}), 3.59$ (br. s, $1 \mathrm{H}), 3.14(\mathrm{t}, J=7.0 \mathrm{~Hz}, 2 \mathrm{H}), 2.73(\mathrm{t}, J=7.6 \mathrm{~Hz}, 2 \mathrm{H}), 1.94$ (quin, $J=7.3 \mathrm{~Hz}, 2 \mathrm{H}) \mathrm{ppm} .{ }^{13} \mathrm{C}$ NMR $\left(125 \mathrm{MHz}, \mathrm{CDCl}_{3}\right) \delta=$ $148.1(\mathrm{C}), 141.6(\mathrm{C}), 129.2(\mathrm{CH}), 128.4(\mathrm{CH}), 128.4(\mathrm{CH}), 125.9$ $(\mathrm{CH}), 117.4(\mathrm{CH}), 112.9(\mathrm{CH}), 43.5\left(\mathrm{CH}_{2}\right), 33.4\left(\mathrm{CH}_{2}\right), 31.0$ $\left(\mathrm{CH}_{2}\right) \mathrm{ppm}$.

Amine 21a. ${ }^{7 g}$ General procedure A was used to synthesize 21a from $N$-methylaniline $(2,214 \mathrm{mg}, 2.0 \mathrm{mmol})$ and methylenecyclohexane $(7,289 \mathrm{mg}, 3.0 \mathrm{mmol})$. After purification by flash chromatography (PE-EtOAc, 100:1), 21a (364 mg, $1.79 \mathrm{mmol}, 90 \%$ ) was isolated as a yellow oil. Prior to chromatography, the ratio $\mathbf{2 1 a} / \mathbf{2 1 b}$ was determined to be $99: 1$. 21a: ${ }^{1} \mathrm{H}$ NMR (300 MHz, $\mathrm{CDCl}_{3}$, TMS) $\delta=7.15$ (t, $\left.J=7.4 \mathrm{~Hz}, 2 \mathrm{H}\right)$, 6.70-6.56 (m, 3H), 3.59 (br. s, 1H), 2.92 (s, 2H), 1.59-1.18 (m, 11H), $0.97(\mathrm{~s}, 3 \mathrm{H}) \mathrm{ppm} .{ }^{13} \mathrm{C}$ NMR $\left(75 \mathrm{MHz}, \mathrm{CDCl}_{3}\right) \delta=149.1$ (C), $129.1(\mathrm{CH}), 116.7(\mathrm{CH}), 112.6(\mathrm{CH}), 54.6\left(\mathrm{CH}_{2}\right), 35.8\left(\mathrm{CH}_{2}\right)$, 34.2 (C), $26.4\left(\mathrm{CH}_{2}\right), 23.5\left(\mathrm{CH}_{3}\right), 22.0\left(\mathrm{CH}_{2}\right) \mathrm{ppm}$.

Amine 22a. ${ }^{5 k}$ General procedure A was used to synthesize 22a from $N$-methylaniline $(2,214 \mathrm{mg}, 2.0 \mathrm{mmol})$ and $\alpha$-methylstyrene $(9,355 \mathrm{mg}, 3.0 \mathrm{mmol})$. After purification by flash chromatography (PE-EtOAc, $100: 1)$, 22a (387 mg, $1.72 \mathrm{mmol}$, $86 \%$ ) was isolated as a yellow oil. Prior to chromatography, the ratio 22a/22b was determined to be 99:1. 22a: ${ }^{1} \mathrm{H}$ NMR $\left(500 \mathrm{MHz}, \mathrm{CDCl}_{3}, \mathrm{TMS}\right) \delta=7.42-7.38(\mathrm{~m}, 2 \mathrm{H}), 7.35(\mathrm{t}, J=7.0$ $\mathrm{Hz}, 2 \mathrm{H}$ ), 7.25-7.21 (m, 1H), 7.13 (br. t, $J=7.3 \mathrm{~Hz}, 2 \mathrm{H}$ ), 6.66 (br. $\mathrm{t}, J=7.3 \mathrm{~Hz}, 1 \mathrm{H}), 6.53$ (br. d, $J=8.5 \mathrm{~Hz}, 2 \mathrm{H}), 3.28(\mathrm{~s}, 2 \mathrm{H}), 1.41$ (s, 6H) ppm. ${ }^{13} \mathrm{C}$ NMR $\left(125 \mathrm{MHz}, \mathrm{CDCl}_{3}\right) \delta=148.7$ (C), 146.7 (C), $129.1(\mathrm{CH}), 128.5(\mathrm{CH}), 126.2(\mathrm{CH}), 126.1(\mathrm{CH}), 117.1(\mathrm{CH})$, $112.7(\mathrm{CH}), 55.7\left(\mathrm{CH}_{2}\right), 38.9(\mathrm{C}), 27.4\left(\mathrm{CH}_{3}\right) \mathrm{ppm}$.

Amine 23a. ${ }^{5 m}$ General procedure A was used to synthesize 23a from $N$-methylaniline $(2,214 \mathrm{mg}, 2.0 \mathrm{mmol})$ and para$\alpha$-dimethylstyrene $(\mathbf{1 0}, 397 \mathrm{mg}, 3.0 \mathrm{mmol})$. After purification by flash chromatography (PE-EtOAc, $100: 1)$, 23a (435 mg, $1.82 \mathrm{mmol}, 91 \%$ ) was isolated as a yellow oil. Prior to chrom- atography, the ratio $\mathbf{2 3 a} \mathbf{2} \mathbf{2 3 b}$ was determined to be $99: 1$. 23a: ${ }^{1} \mathrm{H}$ NMR $\left(500 \mathrm{MHz}, \mathrm{CDCl}_{3}\right.$, TMS) $\delta=7.28$ (br. d, $J=8.2 \mathrm{~Hz}$, $2 \mathrm{H}), 7.22-7.09(\mathrm{~m}, 4 \mathrm{H}), 6.65(\mathrm{t}, J=7.3 \mathrm{~Hz}, 1 \mathrm{H}), 6.53(\mathrm{~d}, J=7.7$ $\mathrm{Hz}, 2 \mathrm{H}), 3.32$ (br. s, 1H), 3.25 (s, 2H), 2.33 (s, 3H), 1.39 (s, 6H) ppm. ${ }^{13} \mathrm{C}$ NMR ( $\left.125 \mathrm{MHz}, \mathrm{CDCl}_{3}\right) \delta=148.7$ (C), 143.6 (C), 135.7 (C), $129.2(\mathrm{CH}), 129.1(\mathrm{CH}), 126.0(\mathrm{CH}), 117.0(\mathrm{CH}), 112.7(\mathrm{CH})$, $55.6\left(\mathrm{CH}_{2}\right), 38.5(\mathrm{C}), 27.5\left(\mathrm{CH}_{3}\right), 20.9\left(\mathrm{CH}_{3}\right) \mathrm{ppm}$.

Amine $24 b^{7 g}$ General procedure A was used to synthesize 24b from $N$-methylaniline $(2,214 \mathrm{mg}, 2.0 \mathrm{mmol})$ and $(E)$ $\beta$-methylstyrene (11, $355 \mathrm{mg}, 3.0 \mathrm{mmol})$. After purification by flash chromatography (PE-EtOAc, 95:1), 24b (288 mg, $1.28 \mathrm{mmol}, 64 \%$ ) was isolated as a yellow oil. Prior to chromatography, the ratio $\mathbf{2 4 a / 2 4 b}$ was determined to be $1: 99$. $\mathbf{2 4 b}$ : ${ }^{1} \mathrm{H}$ NMR $\left(500 \mathrm{MHz}, \mathrm{CDCl}_{3}\right.$, TMS $) \delta=7.28(\mathrm{t}, J=7.4 \mathrm{~Hz}, 2 \mathrm{H})$, $7.22-7.11(\mathrm{~m}, 5 \mathrm{H}), 6.67$ (br. t, $J=7.3 \mathrm{~Hz}, 1 \mathrm{H}), 6.53$ (d, $J=7.7$ $\mathrm{Hz}, 2 \mathrm{H}$ ), 3.66 (br. s, 1H), 3.08 (dd, $J=12.5,6.1 \mathrm{~Hz}, 1 \mathrm{H}$ ), 2.93 $(\mathrm{dd}, J=12.5,7.0 \mathrm{~Hz}, 1 \mathrm{H}), 2.74(\mathrm{dd}, J=13.5,6.4 \mathrm{~Hz}, 1 \mathrm{H}), 2.49$ (dd, $J=13.5,7.8 \mathrm{~Hz}, 1 \mathrm{H}), 2.06$ (octet, $J=6.8 \mathrm{~Hz}, 1 \mathrm{H}), 0.96$ (d, $J$ $=6.7 \mathrm{~Hz}, 3 \mathrm{H}) \mathrm{ppm} .{ }^{13} \mathrm{C}$ NMR $\left(125 \mathrm{MHz}, \mathrm{CDCl}_{3}\right) \delta=148.3(\mathrm{C})$, $140.5(\mathrm{C}), 129.2(\mathrm{CH}), 129.1(\mathrm{CH}), 128.3(\mathrm{CH}), 125.9(\mathrm{CH}), 117.0$ $(\mathrm{CH}), 112.7(\mathrm{CH}), 49.8\left(\mathrm{CH}_{2}\right), 41.3\left(\mathrm{CH}_{2}\right), 35.0(\mathrm{CH}), 18.1$ $\left(\mathrm{CH}_{3}\right) \mathrm{ppm}$.

Amines 25a and 25b. General procedure A was used to synthesize 25a and 25b from $N$-methylaniline $(2,214 \mathrm{mg}$, $2.0 \mathrm{mmol})$ and indene $(\mathbf{1 2}, 348 \mathrm{mg}, 3.0 \mathrm{mmol})$. Purification by flash column chromatography (PE-MTBE, 80:1) gave three fractions as oils. Fraction 1 contained pure compound 25a (30 mg, $0.13 \mathrm{mmol}, 7 \%$ ), fraction 2 contained a mixture of $25 \mathrm{a}$ and $25 \mathbf{b}(203 \mathrm{mg}, 0.91 \mathrm{mmol}, 45 \%)$ and fraction 3 contained pure compound $25 \mathrm{~b}$ (200 $\mathrm{mg}, 0.90 \mathrm{mmol}, 45 \%)$ as yellow oils. Prior to chromatography, the ratio $\mathbf{2 5 a} \mathbf{a} / \mathbf{2 5} \mathbf{b}$ was determined to be $34: 66.25 \mathrm{a}: R_{\mathrm{f}}=0.13(\mathrm{PE}-\mathrm{MTBE}, 80: 1) .{ }^{1} \mathrm{H}$ NMR $(500 \mathrm{MHz}$, $\left.\mathrm{CDCl}_{3}\right) \delta=7.33-7.27(\mathrm{~m}, 2 \mathrm{H}), 7.25-7.18(\mathrm{~m}, 4 \mathrm{H}), 6.74(\mathrm{t}, J=7.3$ $\mathrm{Hz}, 1 \mathrm{H}), 6.67$ (d, $J=7.7 \mathrm{~Hz}, 2 \mathrm{H}), 3.75$ (br. s, 1H), 3.54-3.44 (m, $2 \mathrm{H}), 3.29(\mathrm{dd}, J=11.8,7.3 \mathrm{~Hz}, 1 \mathrm{H}), 3.06-2.98(\mathrm{~m}, 1 \mathrm{H})$, 2.98-2.89 (m, 1H), 2.39-2.30 (m, 1H), 1.99-1.91 (m, 1H) ppm. ${ }^{13} \mathrm{C}$ NMR $\left(125 \mathrm{MHz}, \mathrm{CDCl}_{3}\right) \delta=148.4$ (C), 144.7 (C), 144.4 (C), $129.3(\mathrm{CH}), 126.9(\mathrm{CH}), 126.3(\mathrm{CH}), 124.7(\mathrm{CH}), 124.0(\mathrm{CH})$, $117.4(\mathrm{CH}), 112.8(\mathrm{CH}), 48.0\left(\mathrm{CH}_{2}\right), 44.6(\mathrm{CH}), 31.3\left(\mathrm{CH}_{2}\right), 30.0$ $\left(\mathrm{CH}_{2}\right) \mathrm{ppm}$. IR (ATR) $v_{\max }=3417(\mathrm{w}), 3047(\mathrm{w}), 3019(\mathrm{w}), 2939$ (w), 2847 (w), 1601 (s), 1504 (s), 1319 (m), 1260 (m), 744 (vs), $691(\mathrm{~s}) \mathrm{cm}^{-1}$. GC/MS m/z $=223\left([\mathrm{M}]^{+}\right), 106\left(\left[\mathrm{C}_{7} \mathrm{H}_{8} \mathrm{~N}\right]^{+}\right), 77$ $\left(\left[\mathrm{C}_{6} \mathrm{H}_{5}\right]^{+}\right)$. HRMS (ESI +$) \mathrm{m} / z$ calcd for $\mathrm{C}_{16} \mathrm{H}_{18} \mathrm{~N} 224.1439([\mathrm{M}+$ $\left.\mathrm{H}]^{+}\right)$, found 224.1438. 25b: $R_{\mathrm{f}}=0.10(\mathrm{PE}-\mathrm{MTBE}, 80: 1) \cdot{ }^{1} \mathrm{H}$ NMR $\left(500 \mathrm{MHz}, \mathrm{CDCl}_{3}\right) \delta=7.25-7.15(\mathrm{~m}, 6 \mathrm{H}), 6.72(\mathrm{t}, J=7.3$ $\mathrm{Hz}, 1 \mathrm{H}), 6.64(\mathrm{~d}, J=7.7 \mathrm{~Hz}, 2 \mathrm{H}), 3.74$ (br. s, $1 \mathrm{H}), 3.22$ (d, $J=6.7$ $\mathrm{Hz}, 2 \mathrm{H}), 3.19-3.11(\mathrm{~m}, 2 \mathrm{H}), 2.87-2.75(\mathrm{~m}, 3 \mathrm{H}) \mathrm{ppm} .{ }^{13} \mathrm{C}$ NMR $\left(125 \mathrm{MHz}, \mathrm{CDCl}_{3}\right) \delta=148.4(\mathrm{C}), 142.6(\mathrm{C}), 129.2(\mathrm{CH}), 126.3$ $(\mathrm{CH}), 124.6(\mathrm{CH}), 117.3(\mathrm{CH}), 112.7(\mathrm{CH}), 48.8\left(\mathrm{CH}_{2}\right), 39.1$ (CH), $37.2\left(\mathrm{CH}_{2}\right) \mathrm{ppm}$. IR (ATR) $v_{\max }=3414(\mathrm{w}), 3048(\mathrm{w}), 3020$ (w), $2929(\mathrm{w}), 2900(\mathrm{w}), 2841(\mathrm{w}), 1601(\mathrm{~s}), 1505(\mathrm{~s}), 1316(\mathrm{~m})$, $1256(\mathrm{~m}), 740(\mathrm{vs}), 690(\mathrm{~s}) \mathrm{cm}^{-1}$. GC/MS $\mathrm{m} / \mathrm{z}=223\left([\mathrm{M}]^{+}\right), 106$ $\left(\left[\mathrm{C}_{7} \mathrm{H}_{8} \mathrm{~N}\right]^{+}\right), 93\left(\left[\mathrm{C}_{6} \mathrm{H}_{7} \mathrm{~N}\right]^{+}\right), 77\left(\left[\mathrm{C}_{6} \mathrm{H}_{5}\right]^{+}\right)$. HRMS $(\mathrm{ESI}+) \mathrm{m} / \mathrm{z}$ calcd for $\mathrm{C}_{16} \mathrm{H}_{18} \mathrm{~N} 224.1439\left([\mathrm{M}+\mathrm{H}]^{+}\right)$, found 224.1436.

Amines 26a and 26b. ${ }^{7 g}$ General procedure A was used to synthesize 26a and 26b from $N$-methylaniline $(2,214 \mathrm{mg}$, 
$2.0 \mathrm{mmol})$ and (E)-2-octene $(\mathbf{1 7}, 337 \mathrm{mg}, 3.0 \mathrm{mmol})$. After purification by flash chromatography (PE-EtOAc, 100:1), a mixture of 26a and 26b (69 $\mathrm{mg}, 0.32 \mathrm{mmol}, 16 \%$ ) was isolated as a yellow oil. Prior to chromatography, the ratio $26 \mathbf{a} / \mathbf{2 6 b}$ was determined to be $35: 65$. ${ }^{1} \mathrm{H}$ NMR (500 $\mathrm{MHz}, \mathrm{CDCl}_{3}, \mathrm{TMS}$, mixture of two regioisomers) signals of the major regioisomer 26b: $\delta=7.09(\mathrm{t}, J=8.4 \mathrm{~Hz}, 2 \mathrm{H}), 6.60(\mathrm{t}, J=7.3 \mathrm{~Hz}, 1 \mathrm{H}), 6.53(\mathrm{~d}$, $J=7.6 \mathrm{~Hz}, 2 \mathrm{H}), 3.59$ (br. s, 1H), 3.01-2.92 (m, 1H), 2.80 (dd, $J=$ 12.2, $7.3 \mathrm{~Hz}, 1 \mathrm{H}$ ), 1.66 (octet, $J=6.6 \mathrm{~Hz}, 1 \mathrm{H}$ ), 1.41-1.05 (m, $13 \mathrm{H}), 0.89(\mathrm{~d}, J=6.7 \mathrm{~Hz}, 3 \mathrm{H}), 0.81(\mathrm{t}, J=6.8 \mathrm{~Hz}, 3 \mathrm{H}) \mathrm{ppm}$; important signals of the minor regioisomer 26a: $\delta=3.01-2.92$ (m, 2H), 1.49 (sept, $J=6.1 \mathrm{~Hz}, 1 \mathrm{H}), 0.84$ (t, $J=7.4 \mathrm{~Hz}, 3 \mathrm{H}), 0.82$ $(\mathrm{t}, J=6.8 \mathrm{~Hz}, 3 \mathrm{H}) \mathrm{ppm} .{ }^{13} \mathrm{C} \mathrm{NMR}\left(125 \mathrm{MHz}, \mathrm{CDCl}_{3}\right.$, mixture of two regioisomers) signals of the major regioisomer 26b: $\delta=$ $148.7(\mathrm{C}), 129.2(\mathrm{CH}), 116.9(\mathrm{CH}), 112.6(\mathrm{CH}), 50.3\left(\mathrm{CH}_{2}\right), 34.8$ $\left(\mathrm{CH}_{2}\right), 32.9(\mathrm{CH}), 31.9\left(\mathrm{CH}_{2}\right), 29.6\left(\mathrm{CH}_{2}\right), 26.9\left(\mathrm{CH}_{2}\right), 22.7$ $\left(\mathrm{CH}_{2}\right)$, $18.1\left(\mathrm{CH}_{3}\right), 14.1\left(\mathrm{CH}_{3}\right)$ ppm; signals of the minor regioisomer 26a: $\delta=148.6(\mathrm{C}), 129.2(\mathrm{CH}), 116.9(\mathrm{CH}), 112.6(\mathrm{CH})$, $47.0\left(\mathrm{CH}_{2}\right), 39.1(\mathrm{CH}), 32.3\left(\mathrm{CH}_{2}\right), 31.6\left(\mathrm{CH}_{2}\right), 26.4\left(\mathrm{CH}_{2}\right), 24.5$ $\left(\mathrm{CH}_{2}\right), 22.7\left(\mathrm{CH}_{2}\right), 14.1\left(\mathrm{CH}_{3}\right), 10.9\left(\mathrm{CH}_{3}\right)$ ppm. IR (neat, mixture of two regioisomers) $v_{\max }=3421(\mathrm{~s}), 3052(\mathrm{w}), 3021$ (w), 2957 (s), 2926 (s), 2856 (s), 1603 (s), 1506 (s), 1465 (m), 1320 (m), 1260 (m), 747 (s), 691 (s) $\mathrm{cm}^{-1}$. GC/MS m/z = 219 $\left([\mathrm{M}]^{+}\right), 106\left(\left[\mathrm{C}_{7} \mathrm{H}_{8} \mathrm{~N}\right]^{+}\right), 77\left(\left[\mathrm{C}_{6} \mathrm{H}_{5}\right]^{+}\right)$.

Amine 27. ${ }^{11}$ General procedure A was used to synthesize 27 from $N$-methylaniline $(2,214 \mathrm{mg}, 2.0 \mathrm{mmol})$ and cyclopentene (18, $204 \mathrm{mg}, 3.0 \mathrm{mmol})$. After purification by flash chromatography (PE-EtOAc, 80:1), 27 (262 mg, $1.49 \mathrm{mmol}, 75 \%$ ) was isolated as a yellow oil. 27: ${ }^{1} \mathrm{H}$ NMR (300 $\left.\mathrm{MHz}, \mathrm{CDCl}_{3}, \mathrm{TMS}\right) \delta$ $=7.17$ (br. $\mathrm{t}, J=7.9 \mathrm{~Hz}, 2 \mathrm{H}$ ), 6.68 (br. t $J=7.3 \mathrm{~Hz}, 1 \mathrm{H}), 6.61$ (br. d, $J=8.1 \mathrm{~Hz}, 2 \mathrm{H}), 3.64$ (br. s, $1 \mathrm{H}), 3.02$ (d, $J=7.2 \mathrm{~Hz}, 2 \mathrm{H}$ ), 2.15 (sept, $J=7.5 \mathrm{~Hz}, 1 \mathrm{H}), 1.91-1.72(\mathrm{~m}, 2 \mathrm{H}), 1.67-1.47$ (m, $4 \mathrm{H}), 1.37-1.17$ (m, 2H) ppm. ${ }^{13} \mathrm{C} \mathrm{NMR}\left(75 \mathrm{MHz}, \mathrm{CDCl}_{3}\right) \delta=$ $148.6(\mathrm{C}), 129.2(\mathrm{CH}), 117.0(\mathrm{CH}), 112.6(\mathrm{CH}), 49.5\left(\mathrm{CH}_{2}\right), 39.4$ $(\mathrm{CH}), 30.7\left(\mathrm{CH}_{2}\right), 25.3\left(\mathrm{CH}_{2}\right) \mathrm{ppm}$.

Amine 28. ${ }^{5 k}$ General procedure A was used to synthesize $\mathbf{2 8}$ from $N$-methylaniline $(2,214 \mathrm{mg}, 2.0 \mathrm{mmol})$ and cyclohexene (19, $246 \mathrm{mg}, 3.0 \mathrm{mmol})$. After purification by flash chromatography (PE-EtOAc, $100: 1$ ), 28 (272 mg, $1.44 \mathrm{mmol}, 72 \%$ ) was isolated as a yellow oil. 28: ${ }^{1} \mathrm{H}$ NMR (500 $\mathrm{MHz}, \mathrm{CDCl}_{3}, \mathrm{TMS}$ ) $\delta=7.18-7.13(\mathrm{~m}, 2 \mathrm{H}), 6.67(\mathrm{tt}, J=7.3,1.0 \mathrm{~Hz}, 1 \mathrm{H}), 6.61-6.56$ (m, 2H), 3.71 (br. s, 1H), 2.95 (d, $J=6.7 \mathrm{~Hz}, 2 \mathrm{H}), 1.85-1.78$ (m, $2 \mathrm{H}), 1.78-1.71(\mathrm{~m}, 2 \mathrm{H}), 1.70-1.65(\mathrm{~m}, 1 \mathrm{H}), 1.64-1.52(\mathrm{~m}, 1 \mathrm{H})$, 1.31-1.13 (m, 3H), 0.98 (qd, $J=12.1,3.1 \mathrm{~Hz}, 2 \mathrm{H}) \mathrm{ppm} .{ }^{13} \mathrm{C}$ NMR (125 MHz, $\left.\mathrm{CDCl}_{3}\right) \delta=148.6(\mathrm{C}), 129.2(\mathrm{CH}), 116.9(\mathrm{CH})$, $112.7(\mathrm{CH}), 50.6\left(\mathrm{CH}_{2}\right), 37.6(\mathrm{CH}), 31.3\left(\mathrm{CH}_{2}\right), 26.6\left(\mathrm{CH}_{2}\right), 26.0$ $\left(\mathrm{CH}_{2}\right) \mathrm{ppm}$.

Amine 29. General procedure A was used to synthesize 29 from $N$-methylaniline $(2,214 \mathrm{mg}, 2.0 \mathrm{mmol})$ and 1,4-cyclohexadiene $(\mathbf{2 0}, 240 \mathrm{mg}, 3.0 \mathrm{mmol})$. After purification by flash chromatography (PE-EtOAc, 90:1), 29 (348 mg, $1.86 \mathrm{mmol}$, 93\%) was isolated as a yellow oil. 29: ${ }^{1} \mathrm{H}$ NMR $(500 \mathrm{MHz}$, $\mathrm{CDCl}_{3}, \mathrm{TMS}$ ) $\delta=7.17$ (br. t, $J=6.9 \mathrm{~Hz}, 2 \mathrm{H}$ ), 6.68 (br. t, $J=7.3$ $\mathrm{Hz}, 1 \mathrm{H}), 6.61$ (br. d, $J=8.5 \mathrm{~Hz}, 2 \mathrm{H}), 5.73-5.63(\mathrm{~m}, 2 \mathrm{H}), 3.73$ (br. s, 1H), 3.10-3.01 (m, 2H), 2.24-2.15 (m, 1H), 2.13-2.03 (m, $2 \mathrm{H}), 1.96-1.83(\mathrm{~m}, 2 \mathrm{H}), 1.83-1.74(\mathrm{~m}, 1 \mathrm{H}), 1.39-1.28(\mathrm{~m}, 1 \mathrm{H})$ ppm. ${ }^{13} \mathrm{C}$ NMR $\left(125 \mathrm{MHz}, \mathrm{CDCl}_{3}\right) \delta=148.5(\mathrm{C}), 129.2(\mathrm{CH})$, $127.2(\mathrm{CH}), 125.8(\mathrm{CH}), 117.0(\mathrm{CH}), 112.6(\mathrm{CH}), 49.7\left(\mathrm{CH}_{2}\right)$, $33.5(\mathrm{CH}), 29.7\left(\mathrm{CH}_{2}\right), 26.8\left(\mathrm{CH}_{2}\right), 24.7\left(\mathrm{CH}_{2}\right)$ ppm. IR (neat) $v_{\max }=3418(\mathrm{~m}), 3051(\mathrm{w}), 3021(\mathrm{~m}), 2916(\mathrm{~s}), 2837(\mathrm{~m}), 1603$ (s), 1507 (s), 1433 (m), 1323 (s), 1254 (s), 1179 (w), 748 (s), 692 (s) $\mathrm{cm}^{-1}$. GC/MS m/z = $187\left([\mathrm{M}]^{+}\right), 106\left(\left[\mathrm{C}_{7} \mathrm{H}_{8} \mathrm{~N}\right]^{+}\right), 77\left(\left[\mathrm{C}_{6} \mathrm{H}_{5}\right]^{+}\right)$. HRMS (ESI +$) m / z$ calcd for $\mathrm{C}_{13} \mathrm{H}_{18} \mathrm{~N} 188.1439\left([\mathrm{M}+\mathrm{H}]^{+}\right)$, found 188.1435 .

Amine 31. ${ }^{12}$ General procedure A was used to synthesize 31 from $\mathrm{N}$-methylaniline $(2,214 \mathrm{mg}, 2.0 \mathrm{mmol})$ and 3-methoxycyclohexene (30, $337 \mathrm{mg}, 3.0 \mathrm{mmol})$. After purification by flash chromatography $\left(\mathrm{PE}-\mathrm{Et}_{2} \mathrm{O}, \quad 80: 1 \rightarrow \mathrm{PE}-\mathrm{Et}_{2} \mathrm{O}, \quad 40: 1\right), 31$ (228 mg, $1.22 \mathrm{mmol}, 61 \%$ ) was isolated as a yellow oil. $31:{ }^{1} \mathrm{H}$ NMR (500 MHz, $\left.\mathrm{CDCl}_{3}, \mathrm{TMS}\right) \delta=7.27-7.18(\mathrm{~m}, 2 \mathrm{H}), 6.79$ (d, $J=$ $8.3 \mathrm{~Hz}, 2 \mathrm{H}), 6.69$ (t, J = 7.2 Hz, 1H), 5.94-5.88 (m, 1H), 5.63 (br. $\mathrm{d}, J=10.2 \mathrm{~Hz}, 1 \mathrm{H}), 4.48-4.41(\mathrm{~m}, 1 \mathrm{H}), 2.78(\mathrm{~s}, 3 \mathrm{H}), 2.12-1.95$ $(\mathrm{m}, 2 \mathrm{H}), 1.91-1.77(\mathrm{~m}, 2 \mathrm{H}), 1.71-1.52(\mathrm{~m}, 2 \mathrm{H}) \mathrm{ppm} .{ }^{13} \mathrm{C} \mathrm{NMR}$ $\left(125 \mathrm{MHz} \mathrm{CDCl}_{3}\right) \delta=149.7(\mathrm{C}), 130.6(\mathrm{CH}), 129.9(\mathrm{CH}), 129.1$ $(\mathrm{CH}), 116.2(\mathrm{CH}), 112.8(\mathrm{CH}), 54.9(\mathrm{CH}), 32.4\left(\mathrm{CH}_{3}\right), 25.3\left(\mathrm{CH}_{2}\right)$, $24.9\left(\mathrm{CH}_{2}\right), 21.5\left(\mathrm{CH}_{2}\right)$ ppm.

Amine 39a. General procedure A was used to synthesize 39a from para-methyl- $N$-methylaniline $(32,242 \mathrm{mg}, 2.0 \mathrm{mmol})$ and $\alpha$-methylstyrene $(9,355 \mathrm{mg}, 3.0 \mathrm{mmol})$. After purification by flash chromatography (PE-EtOAc, 95:1), 39a (422 mg, $1.76 \mathrm{mmol}, 88 \%$ ) was isolated as a yellow oil. Prior to chromatography, the ratio $39 a / 39 b$ was determined to be $99: 1$. 39a: ${ }^{1} \mathrm{H}$ NMR (500 MHz, $\left.\mathrm{CDCl}_{3}, \mathrm{TMS}\right) \delta=7.39$ (br. d, $J=7.8 \mathrm{~Hz}$, $2 \mathrm{H}), 7.34$ (t, $J=7.8 \mathrm{~Hz}, 2 \mathrm{H}), 7.22$ (br. t, $J=7.3 \mathrm{~Hz}, 1 \mathrm{H}), 6.94$ (d, $J=8.0 \mathrm{~Hz}, 2 \mathrm{H}), 6.45$ (d, $J=8.4 \mathrm{~Hz}, 2 \mathrm{H}), 3.25$ (s, 2H), 3.17 (br. s, $1 \mathrm{H}), 2.21$ (s, 3H), 1.40 (s, 6H) ppm. ${ }^{13} \mathrm{C} \mathrm{NMR} \mathrm{(125} \mathrm{MHz,} \mathrm{CDCl}_{3}$ ) $\delta 146.8(\mathrm{C}), 146.5(\mathrm{C}), 129.6(\mathrm{CH}), 128.5(\mathrm{CH}), 126.2(\mathrm{C}), 126.1$ $(\mathrm{CH}), 126.1(\mathrm{CH}), 112.8(\mathrm{CH}), 56.1\left(\mathrm{CH}_{2}\right), 38.9(\mathrm{C}), 27.4\left(\mathrm{CH}_{3}\right)$, $20.3\left(\mathrm{CH}_{3}\right) \mathrm{ppm}$. IR (neat) $v_{\max }=3413(\mathrm{~m}), 3021(\mathrm{~m}), 2964(\mathrm{~m})$, 2920 (m), 1619 (s), 1521 (s), 1480 (m), 1317 (m), 1294 (m), 1251 (m), 806 (s), $764(\mathrm{~m}), 700(\mathrm{~s}) \mathrm{cm}^{-1}$. GC/MS m/z = $239\left([\mathrm{M}]^{+}\right), 120$ $\left(\left[\mathrm{C}_{8} \mathrm{H}_{10} \mathrm{~N}\right]^{+}\right), \quad 91 \quad\left(\left[\mathrm{C}_{7} \mathrm{H}_{7}\right]^{+}\right)$. HRMS (ESI+) $\mathrm{m} / \mathrm{z}$ calcd for $\mathrm{C}_{17} \mathrm{H}_{21} \mathrm{NNa} 262.1572\left([\mathrm{M}+\mathrm{Na}]^{+}\right)$, found 262.1567.

Amine 40a. General procedure A was used to synthesize 40a from para-fluoro- $N$-methylaniline $(33,250 \mathrm{mg}, 2.0 \mathrm{mmol})$ and $\alpha$-methylstyrene $(\mathbf{9}, 355 \mathrm{mg}, 3.0 \mathrm{mmol})$. After purification by flash chromatography (PE-EtOAc, 80:1), 40a (475 mg, $1.95 \mathrm{mmol}$, 98\%) was isolated as a yellow oil. Prior to chromatography, the ratio $\mathbf{4 0 a} / \mathbf{4 0 b}$ was determined to be $99: 1$. 40a: ${ }^{1} \mathrm{H}$ NMR (300 MHz, $\left.\mathrm{CDCl}_{3}, \mathrm{TMS}\right) \delta=7.43-7.30(\mathrm{~m}, 4 \mathrm{H}), 7.23$ (tt, $J=6.8,1.7 \mathrm{~Hz}, 1 \mathrm{H}), 6.87-6.77(\mathrm{~m}, 2 \mathrm{H}), 6.49-6.39(\mathrm{~m}, 2 \mathrm{H})$, 3.22 (s, 2H), 3.21 (br. s, 1H), 1.41 (s, 6H) ppm. ${ }^{13} \mathrm{C}$ NMR $\left(75 \mathrm{MHz}, \mathrm{CDCl}_{3}\right) \delta=155.6\left(\mathrm{~d},{ }^{1} J_{\mathrm{C}, \mathrm{F}}=234.5 \mathrm{~Hz}, \mathrm{C}\right), 146.6$ (C), $145.1(\mathrm{C}), 128.5(\mathrm{CH}), 126.2(\mathrm{CH}), 126.0(\mathrm{CH}), 115.5\left(\mathrm{~d},{ }^{2} J_{\mathrm{C}, \mathrm{F}}=\right.$ $22.2 \mathrm{~Hz}, \mathrm{CH}), 113.5\left(\mathrm{~d},{ }^{3} J_{\mathrm{C}, \mathrm{F}}=7.4 \mathrm{~Hz}, \mathrm{CH}\right), 56.5\left(\mathrm{CH}_{2}\right), 38.8(\mathrm{C})$, $27.4\left(\mathrm{CH}_{3}\right)$ ppm. IR (neat) $v_{\max }=3412(\mathrm{w}), 3059(\mathrm{w}), 2965(\mathrm{~m})$, 1612 (w), 1511 (s), 1481 (m), 1221 (s), 819 (s), 765 (s), 701 (s) $\mathrm{cm}^{-1}$. GC/MS m/z = $243\left([\mathrm{M}]^{+}\right), 124\left(\left[\mathrm{C}_{7} \mathrm{H}_{7} \mathrm{NF}\right]^{+}\right), 91\left(\left[\mathrm{C}_{7} \mathrm{H}_{7}\right]^{+}\right)$. HRMS (ESI+) $m / z$ calcd for $\mathrm{C}_{16} \mathrm{H}_{19} \mathrm{NF} 244.1502\left([\mathrm{M}+\mathrm{H}]^{+}\right)$, found 244.1503.

Amine 41a. General procedure A was used to synthesize 41a from para-phenoxy- $N$-methylaniline $(34,399 \mathrm{mg}, 2.0 \mathrm{mmol})$ 
and $\alpha$-methylstyrene $(9,355 \mathrm{mg}, 3.0 \mathrm{mmol})$. After purification by flash chromatography (PE-EtOAc, 60:1), 41a $(424 \mathrm{mg}$, $1.34 \mathrm{mmol}, 67 \%$ ) was isolated as a yellow solid. Prior to chromatography, the ratio $41 \mathrm{a} / \mathbf{4 1} \mathrm{b}$ was determined to be $99: 1$. 41a: ${ }^{1} \mathrm{H}$ NMR $\left(500 \mathrm{MHz}, \mathrm{CDCl}_{3}\right.$, TMS) $\delta=7.40$ (br. d, $J=8.3 \mathrm{~Hz}$, $2 \mathrm{H}), 7.37-7.32(\mathrm{~m}, 2 \mathrm{H}), 7.27-7.21(\mathrm{~m}, 3 \mathrm{H}), 6.98(\mathrm{t}, J=7.4 \mathrm{~Hz}$, $1 \mathrm{H}), 6.90(\mathrm{~d}, J=8.4 \mathrm{~Hz}, 2 \mathrm{H}), 6.85$ (br. d, $J=8.8 \mathrm{~Hz}, 2 \mathrm{H}), 6.51$ (br. d, $J=8.8 \mathrm{~Hz}, 2 \mathrm{H}$ ), 3.26 (br. s, $3 \mathrm{H}), 1.42$ (s, 6H) ppm. ${ }^{13} \mathrm{C}$ NMR (125 MHz, $\left.\mathrm{CDCl}_{3}\right) \delta=159.1$ (C), 147.3 (C), 146.6 (C), $145.4(\mathrm{C}), 129.4(\mathrm{CH}), 128.5(\mathrm{CH}), 126.2(\mathrm{CH}), 126.0(\mathrm{CH}), 121.8$ $(\mathrm{CH}), 121.2(\mathrm{CH}), 116.9(\mathrm{CH}), 113.7(\mathrm{CH}), 56.4\left(\mathrm{CH}_{2}\right), 38.8(\mathrm{C})$, $27.4\left(\mathrm{CH}_{3}\right) \mathrm{ppm}$. IR (neat) $v_{\max }=3412(\mathrm{~s}), 3053(\mathrm{w}), 3034(\mathrm{w})$, 2965 (m), 2924 (w), $2854(\mathrm{w}), 1613$ (s), 1517 (s), 1489 (m), 1233 (s), $1163(\mathrm{~m}), 832(\mathrm{~m}), 752(\mathrm{~m}), 704(\mathrm{~m}), 692(\mathrm{~m}) \mathrm{cm}^{-1}$. GC/MS $m / z=317\left([\mathrm{M}]^{+}\right), 198\left(\left[\mathrm{C}_{13} \mathrm{H}_{12} \mathrm{NO}\right]^{+}\right), 91\left(\left[\mathrm{C}_{7} \mathrm{H}_{7}\right]^{+}\right)$. HRMS (ESI +$)$ $m / z$ calcd for $\mathrm{C}_{22} \mathrm{H}_{23} \mathrm{NONa} 340.1677\left([\mathrm{M}+\mathrm{Na}]^{+}\right)$, found 340.1681 .

para-Toluenesulfonamide 42a. General procedure B was used to synthesize 42a from $N$-methylcyclohexylamine (36, $226 \mathrm{mg}, \quad 2.0 \mathrm{mmol})$ and $\alpha$-methylstyrene $(9,355 \mathrm{mg}$, $3.0 \mathrm{mmol}$ ). After purification by flash chromatography (PEEtOAc, 80:1 $\rightarrow$ PE-EtOAc, 40:1 $\rightarrow$ PE-EtOAc, 20:1), 42a (107 mg, $0.28 \mathrm{mmol}, 14 \%$ ) was isolated as a colorless solid. Prior to tosylation and chromatography, the ratio of the branched and the linear product was determined to be $99: 1$. 42a: ${ }^{1} \mathrm{H}$ NMR $\left(500 \mathrm{MHz}, \mathrm{CDCl}_{3}, \mathrm{TMS}\right) \delta=7.68(\mathrm{~d}, J=8.3 \mathrm{~Hz}$, $2 \mathrm{H}), 7.40-7.35(\mathrm{~m}, 2 \mathrm{H}), 7.32$ (br. t, $J=7.8 \mathrm{~Hz}, 2 \mathrm{H}), 7.26-7.24$ (m, 2H), 7.21 (br. t, $J=7.3 \mathrm{~Hz}, 1 \mathrm{H}), 3.44(\mathrm{~s}, 2 \mathrm{H}), 2.53-2.45(\mathrm{~m}$, $1 \mathrm{H}), 2.41(\mathrm{~s}, 3 \mathrm{H}), 1.39(\mathrm{~s}, 6 \mathrm{H}), 1.35-1.12(\mathrm{~m}, 7 \mathrm{H}), 0.74-0.59(\mathrm{~m}$, $3 \mathrm{H}) \mathrm{ppm} .{ }^{13} \mathrm{C}$ NMR $\left(125 \mathrm{MHz}, \mathrm{CDCl}_{3}\right) \delta 147.9$ (C), 142.7 (C), $139.2(\mathrm{C}), 129.4(\mathrm{CH}), 128.2(\mathrm{CH}), 127.3(\mathrm{CH}), 126.3(\mathrm{CH}), 126.1$ $(\mathrm{CH}), 60.9(\mathrm{CH}), 59.4\left(\mathrm{CH}_{2}\right), 39.0(\mathrm{C}), 31.4\left(\mathrm{CH}_{2}\right), 27.3\left(\mathrm{CH}_{3}\right)$, $26.6\left(\mathrm{CH}_{2}\right), 25.1\left(\mathrm{CH}_{2}\right), 21.5\left(\mathrm{CH}_{3}\right) \mathrm{ppm}$. IR (neat) $v_{\max }=3029$ (w), $2940(\mathrm{~m}), 2859(\mathrm{~m}), 1601$ (s), $1494(\mathrm{~m}), 1371(\mathrm{~s}), 1161(\mathrm{~s})$, 1045 (w), $816(\mathrm{~m}), 761(\mathrm{~s}), 705(\mathrm{~s}) \mathrm{cm}^{-1}$. MS (ESI +$) \mathrm{m} / z=408$ $\left([\mathrm{M}+\mathrm{Na}]^{+}\right.$). HRMS (ESI+) $\mathrm{m} / z$ calcd for $\mathrm{C}_{23} \mathrm{H}_{31} \mathrm{NO}_{2} \mathrm{SNa}$ $408.1973\left([\mathrm{M}+\mathrm{Na}]^{+}\right)$, found 408.1980 .

para-Toluenesulfonamide 43a. General procedure B was used to synthesize 43a from $N$-methylhexylamine $(37,230 \mathrm{mg}$, $2.0 \mathrm{mmol})$ and $\alpha$-methylstyrene $(9,355 \mathrm{mg}, 3.0 \mathrm{mmol})$. After purification by flash chromatography (PE-EtOAc, $80: 1 \rightarrow$ PEEtOAc, 40:1 $\rightarrow$ PE-EtOAc, 30:1), a mixture of 43a and tosylated $N$-methylhexylamine $(421 \mathrm{mg})$ was isolated as a colorless oil. According to ${ }^{1} \mathrm{H}$ NMR spectroscopy, the mixture contained $380 \mathrm{mg}$ of $43 \mathrm{a}(0.98 \mathrm{mmol}, 49 \%)$ and $41 \mathrm{mg}$ of tosylated $\mathrm{N}$ methylhexylamine $(0.15 \mathrm{mmol})$. Prior to tosylation and chromatography, the ratio of the branched and the linear product was determined to be $99: 1$. 43a: ${ }^{1} \mathrm{H}$ NMR $\left(500 \mathrm{MHz}, \mathrm{CDCl}_{3}\right.$, TMS) $\delta=7.65$ (d, $J=8.3 \mathrm{~Hz}, 2 \mathrm{H}), 7.37$ (br. d, $J=8.1 \mathrm{~Hz}, 2 \mathrm{H}$ ), 7.33-7.24 (m, $4 \mathrm{H}), 7.19$ (br. t, $J=7.3 \mathrm{~Hz}, 1 \mathrm{H}), 3.39$ (s, 2H), 2.54-2.47 (m, 2H), $2.41(\mathrm{~s}, 3 \mathrm{H}), 1.41(\mathrm{~s}, 6 \mathrm{H}), 1.12-0.98(\mathrm{~m}, 3 \mathrm{H})$, $0.95-0.85(\mathrm{~m}, 3 \mathrm{H}), 0.78(\mathrm{t}, J=7.3 \mathrm{~Hz}, 3 \mathrm{H}), 0.62$ (pent, $J=7.6$ $\mathrm{Hz}, 2 \mathrm{H}) \mathrm{ppm} .{ }^{13} \mathrm{C} \mathrm{NMR}\left(125 \mathrm{MHz}, \mathrm{CDCl}_{3}\right) \delta=147.4(\mathrm{C}), 142.9$ (C), $137.3(\mathrm{C}), 129.5(\mathrm{CH}), 128.2(\mathrm{CH}), 127.2(\mathrm{CH}), 126.1(\mathrm{CH})$, $126.0(\mathrm{CH}), 59.7\left(\mathrm{CH}_{2}\right), 49.3\left(\mathrm{CH}_{2}\right), 39.0(\mathrm{C}), 31.1\left(\mathrm{CH}_{2}\right), 27.1$ $\left(\mathrm{CH}_{3}\right), 27.1\left(\mathrm{CH}_{2}\right), 26.3\left(\mathrm{CH}_{2}\right), 22.4\left(\mathrm{CH}_{2}\right), 21.5\left(\mathrm{CH}_{3}\right), 13.9$
$\left(\mathrm{CH}_{3}\right) \mathrm{ppm}$. IR (neat) $v_{\max }=2958(\mathrm{~s}), 2929(\mathrm{~s}), 2858(\mathrm{~m}), 1599$ (m), 1495 (m), 1465 (m), 1340 (s), 1160 (s), 1091 (m), 815 (m), $757(\mathrm{~m}), 702(\mathrm{~s}), 655(\mathrm{~s}) \mathrm{cm}^{-1}$. MS (ESI +$) \mathrm{m} / z=410\left([\mathrm{M}+\mathrm{Na}]^{+}\right)$. HRMS (ESI + ) $m / z$ calcd for $\mathrm{C}_{23} \mathrm{H}_{33} \mathrm{NO}_{2} \mathrm{SNa} 410.2130$ ([M + $\mathrm{Na}]^{+}$), found 410.2123 .

Amine $\mathbf{4 4 b}^{7 b}$ General procedure A was used to synthesize 44b from para-methyl- $N$-methylaniline (32, $242 \mathrm{mg}, 2.0 \mathrm{mmol})$ and $(E)$ - $\beta$-methylstyrene $(\mathbf{1 1}, 355 \mathrm{mg}, 3.0 \mathrm{mmol})$. After purification by flash chromatography (PE-EtOAc, 95:1), 44b (150 mg, $0.63 \mathrm{mmol}, 31 \%$ ) was isolated as a yellow oil. Prior to chromatography, the ratio $\mathbf{4 4 a / 4 4 b}$ was determined to be $1: 99$. 44b: ${ }^{1} \mathrm{H}$ NMR (500 MHz, $\mathrm{CDCl}_{3}$, TMS) $\delta=7.28(\mathrm{t}, J=7.4 \mathrm{~Hz}$, $2 \mathrm{H}), 7.22-7.13(\mathrm{~m}, 3 \mathrm{H}), 6.96(\mathrm{~d}, J=8.1 \mathrm{~Hz}, 2 \mathrm{H}), 6.47$ (br. d, $J=$ $8.4 \mathrm{~Hz}, 2 \mathrm{H}$ ), 3.53 (br. s, $1 \mathrm{H}$ ), 3.06 (dd, $J=12.4,6.0 \mathrm{~Hz}, 1 \mathrm{H}$ ), $2.92(\mathrm{dd}, J=12.4,6.9 \mathrm{~Hz}, 1 \mathrm{H}), 2.74(\mathrm{dd}, J=13.4,6.4 \mathrm{~Hz}, 1 \mathrm{H})$, 2.49 (dd, $J=13.5,7.9 \mathrm{~Hz}, 1 \mathrm{H}$ ), $2.22(\mathrm{~s}, 3 \mathrm{H}$ ), 2.06 (oct, $J=6.7 \mathrm{~Hz}$, $1 \mathrm{H}), 0.96(\mathrm{~d}, J=6.7 \mathrm{~Hz}, 3 \mathrm{H}) \mathrm{ppm} .{ }^{13} \mathrm{C} \mathrm{NMR}\left(125 \mathrm{MHz}, \mathrm{CDCl}_{3}\right) \delta$ $=146.1(\mathrm{C}), 140.6(\mathrm{C}), 129.7(\mathrm{CH}), 129.1(\mathrm{CH}), 128.2(\mathrm{CH}), 126.3$ (C), $125.9(\mathrm{CH}), 112.9(\mathrm{CH}), 50.2\left(\mathrm{CH}_{2}\right), 41.4\left(\mathrm{CH}_{2}\right), 35.0(\mathrm{CH})$, $20.3\left(\mathrm{CH}_{3}\right), 18.1\left(\mathrm{CH}_{3}\right) \mathrm{ppm}$.

Amine 45b. General procedure A was used to synthesize $\mathbf{4 5 b}$ from para-fluoro- $N$-methylaniline $(33,250 \mathrm{mg}, 2.0 \mathrm{mmol})$ and (E)- $\beta$-methylstyrene (11, $355 \mathrm{mg}, 3.0 \mathrm{mmol})$. After purification by flash chromatography (PE-EtOAc, 80:1), 45b (316 mg, $1.30 \mathrm{mmol}, 65 \%)$ was isolated as a red oil. Prior to chromatography, the ratio $\mathbf{4 5 a} / \mathbf{4 5 b}$ was determined to be $2: 98 . \mathbf{4 5 b}:{ }^{1} \mathrm{H}$ NMR (300 MHz, $\mathrm{CDCl}_{3}$, TMS) $\delta=7.37-7.11(\mathrm{~m}, 5 \mathrm{H}), 6.91-6.79$ (m, 2H), 6.50-6.38 (m, 2H), 3.52 (br. s, 1H), 3.03 (dd, $J=12.3$, $6.1 \mathrm{~Hz}, 1 \mathrm{H}), 2.90(\mathrm{dd}, J=12.3,6.9 \mathrm{~Hz}, 1 \mathrm{H}), 2.73(\mathrm{dd}, J=13.5$, $6.5 \mathrm{~Hz}, 1 \mathrm{H}), 2.51(\mathrm{dd}, J=13.5,7.7 \mathrm{~Hz}, 1 \mathrm{H}), 2.05$ (oct, $J=6.7 \mathrm{~Hz}$, $1 \mathrm{H}), 0.97(\mathrm{~d}, J=6.7 \mathrm{~Hz}, 3 \mathrm{H}) \mathrm{ppm} .{ }^{13} \mathrm{C}$ NMR $\left(75 \mathrm{MHz}, \mathrm{CDCl}_{3}\right) \delta$ $=155.6\left(\mathrm{~d},{ }^{1} J_{\mathrm{C}, \mathrm{F}}=234.4 \mathrm{~Hz}, \mathrm{C}\right), 144.7(\mathrm{C}), 140.4(\mathrm{C}), 129.1(\mathrm{CH})$, $128.3(\mathrm{CH}), 126.0(\mathrm{CH}), 115.6\left(\mathrm{~d},{ }^{2} J_{\mathrm{C}, \mathrm{F}}=22.2 \mathrm{~Hz}, \mathrm{CH}\right), 113.4(\mathrm{~d}$, $\left.{ }^{3} J_{\mathrm{C}, \mathrm{F}}=7.4 \mathrm{~Hz}, \mathrm{CH}\right), 50.5\left(\mathrm{CH}_{2}\right), 41.4\left(\mathrm{CH}_{2}\right), 35.0(\mathrm{CH}), 18.1$ $\left(\mathrm{CH}_{3}\right)$ ppm. IR (neat) $v_{\max }=3422(\mathrm{~m}), 3061(\mathrm{w}), 3027(\mathrm{~m}), 2958$ (m), 2925 (m), 1612 (m), 1511 (s), 1454 (m), 1319 (w), 1256 (m), $1221(\mathrm{~s}), 819(\mathrm{~s}), 741(\mathrm{~s}), 701(\mathrm{~s}) \mathrm{cm}^{-1}$. GC/MS m/z = $243\left([\mathrm{M}]^{+}\right)$, $124\left(\left[\mathrm{C}_{7} \mathrm{H}_{7} \mathrm{NF}\right]^{+}\right), 91\left(\left[\mathrm{C}_{7} \mathrm{H}_{7}\right]^{+}\right)$. HRMS (ESI +$) \mathrm{m} / z$ calcd for $\mathrm{C}_{16} \mathrm{H}_{19} \mathrm{FN} 244.1502\left([\mathrm{M}+\mathrm{H}]^{+}\right)$, found 244.1496.

Amine 46b. General procedure A was used to synthesize 46b from para-phenoxy- $N$-methylaniline (34, $399 \mathrm{mg}, 2.0 \mathrm{mmol}$ ) and $(E)$ - $\beta$-methylstyrene $(\mathbf{1 1}, 355 \mathrm{mg}, 3.0 \mathrm{mmol})$. After purification by flash chromatography (PE-EtOAc, $80: 1 \rightarrow$ PE-EtOAc, $20: 1)$, 46b (88 mg, $0.28 \mathrm{mmol}, 14 \%$ ) was isolated as a dark yellow solid. Prior to chromatography, the ratio $46 \mathrm{a} / \mathbf{4 6 b}$ was determined to be $1: 99 . \mathbf{4 6 b}:{ }^{1} \mathrm{H}$ NMR $\left(500 \mathrm{MHz}, \mathrm{CDCl}_{3}\right.$, TMS) $\delta=7.31-7.24(\mathrm{~m}, 4 \mathrm{H}), 7.23-7.14(\mathrm{~m}, 3 \mathrm{H}), 6.99$ (br. t, $J=7.4 \mathrm{~Hz}$, 1H), 6.92 (br. d, $J=7.7 \mathrm{~Hz}, 2 \mathrm{H}), 6.87$ (br. d, $J=8.8 \mathrm{~Hz}, 2 \mathrm{H}$ ), 6.54 (br. d, $J=8.9 \mathrm{~Hz}, 2 \mathrm{H}$ ), 3.58 (br. s, $1 \mathrm{H}), 3.08$ (dd, $J=12.3$, $6.0 \mathrm{~Hz}, 1 \mathrm{H}), 2.94(\mathrm{dd}, J=12.3,7.0 \mathrm{~Hz}, 1 \mathrm{H}), 2.75(\mathrm{dd}, J=13.5$, $6.5 \mathrm{~Hz}, 1 \mathrm{H}), 2.52$ (dd, $J=13.5,7.7 \mathrm{~Hz}, 1 \mathrm{H}$ ), 2.08 (oct, $J=6.7 \mathrm{~Hz}$, $1 \mathrm{H}), 0.99(\mathrm{~d}, J=6.7 \mathrm{~Hz}, 3 \mathrm{H}) \mathrm{ppm} .{ }^{13} \mathrm{C} \mathrm{NMR}\left(125 \mathrm{MHz}, \mathrm{CDCl}_{3}\right)$ $\delta=159.2$ (C), 147.4 (C), 145.1 (C), 140.5 (C), 129.5 (CH), 129.1 $(\mathrm{CH}), 128.3(\mathrm{CH}), 126.0(\mathrm{CH}), 121.9(\mathrm{CH}), 121.2(\mathrm{CH}), 117.1$ $(\mathrm{CH}), 113.7(\mathrm{CH}), 50.5\left(\mathrm{CH}_{2}\right), 41.4\left(\mathrm{CH}_{2}\right), 35.1(\mathrm{CH}), 18.1\left(\mathrm{CH}_{3}\right)$ ppm. IR (neat) $v_{\max }=3026(\mathrm{~m}), 2957(\mathrm{~m}), 2925(\mathrm{~m}), 2870(\mathrm{~m})$, 
$1613(\mathrm{~m}), 1589(\mathrm{~m}), 1512(\mathrm{~s}), 1488(\mathrm{~s}), 1232(\mathrm{~s}), 869(\mathrm{~s}), 832(\mathrm{~s})$, $745(\mathrm{~s}), 700(\mathrm{~s}), 692(\mathrm{~s}) \mathrm{cm}^{-1}$. GC/MS $\mathrm{m} / z=317\left([\mathrm{M}]^{+}\right), 198$ $\left(\left[\mathrm{C}_{13} \mathrm{H}_{12} \mathrm{NO}\right]^{+}\right), 91 \quad\left(\left[\mathrm{C}_{7} \mathrm{H}_{7}\right]^{+}\right)$. HRMS (ESI +$) \mathrm{m} / \mathrm{z}$ calcd for $\mathrm{C}_{22} \mathrm{H}_{24} \mathrm{NO} 318.1858\left([\mathrm{M}+\mathrm{H}]^{+}\right)$, found 318.1854.

para-Toluenesulfonamide $47 \mathrm{~b}$. General procedure B was used to synthesize $\mathbf{4 7 b}$ from $N$-methylcyclohexylamine (36, $226 \mathrm{mg}, 2.0 \mathrm{mmol}$ ) and (E)- $\beta$-methylstyrene (11, $355 \mathrm{mg}$, $3.0 \mathrm{mmol}$ ). After purification by flash chromatography (PEEtOAc, 80:1 $\rightarrow$ PE-EtOAc, 40:1 $\rightarrow$ PE-EtOAc, 20:1), 47b (294 mg, $0.76 \mathrm{mmol}, 38 \%$ ) was isolated as a colorless solid. Prior to tosylation and chromatography, the ratio of the $\alpha$ - and the $\beta$-alkylated product was determined to be $1: 99.47 \mathrm{~b}:{ }^{1} \mathrm{H}$ NMR $\left(300 \mathrm{MHz}, \mathrm{CDCl}_{3}, \mathrm{TMS}\right) \delta=7.64(\mathrm{~d}, J=8.3 \mathrm{~Hz}, 2 \mathrm{H})$, 7.35-7.10 (m, 7H), 3.66-3.53 (m, 1H), 3.06 (dd, $J=14.4,6.9$, $1 \mathrm{H}), 2.97(\mathrm{dd}, J=14.4,7.7,1 \mathrm{H}), 2.82(\mathrm{dd}, J=13.0,5.0 \mathrm{~Hz}, 1 \mathrm{H})$, $2.40(\mathrm{~s}, 3 \mathrm{H}), 2.36-2.11(\mathrm{~m}, 2 \mathrm{H}), 1.77-1.49(\mathrm{~m}, 5 \mathrm{H}), 1.38-1.12$ $(\mathrm{m}, 5 \mathrm{H}), 0.90(\mathrm{~d}, J=6.4 \mathrm{~Hz}, 3 \mathrm{H}) \mathrm{ppm} .{ }^{13} \mathrm{C}$ NMR $(125 \mathrm{MHz}$, $\left.\mathrm{CDCl}_{3}\right) \delta=142.7$ (C), $140.8(\mathrm{C}), 138.0(\mathrm{C}), 129.5(\mathrm{CH}), 129.0$ $(\mathrm{CH}), 128.2(\mathrm{CH}), 126.9(\mathrm{CH}), 125.8(\mathrm{CH}), 58.5(\mathrm{CH}), 50.2$ $\left(\mathrm{CH}_{2}\right), 41.0\left(\mathrm{CH}_{2}\right), 35.8(\mathrm{CH}), 31.9\left(\mathrm{CH}_{2}\right), 31.8\left(\mathrm{CH}_{2}\right), 26.2$ $\left(\mathrm{CH}_{2}\right), 26.2\left(\mathrm{CH}_{2}\right), 25.4\left(\mathrm{CH}_{2}\right), 21.4\left(\mathrm{CH}_{3}\right), 17.5\left(\mathrm{CH}_{3}\right)$ ppm. IR (neat) $v_{\max }=3027(\mathrm{~m}), 2935(\mathrm{~s}), 2856(\mathrm{~s}), 1599(\mathrm{~s}), 1494(\mathrm{~s})$, $1453(\mathrm{~s}), 1334(\mathrm{~s}), 1155(\mathrm{~s}), 1090(\mathrm{~m}), 1005(\mathrm{~m}), 988(\mathrm{~m}), 849$ (m), $814(\mathrm{~m}), 742(\mathrm{~m}), 702(\mathrm{~s}), 661(\mathrm{~s}) \mathrm{cm}^{-1}$. MS (ESI+) $\mathrm{m} / \mathrm{z}=$ $408\left([\mathrm{M}+\mathrm{Na}]^{+}\right)$. HRMS (ESI +$) \mathrm{m} / z$ calcd for $\mathrm{C}_{23} \mathrm{H}_{31} \mathrm{NO}_{2} \mathrm{NaS}$ $408.1973\left([\mathrm{M}+\mathrm{Na}]^{+}\right)$, found 408.1967.

para-Toluenesulfonamide $48 \mathrm{~b}$. General procedure $\mathrm{B}$ was used to synthesize $\mathbf{4 8 b}$ from $N$-methylhexylamine $(37,230 \mathrm{mg}$, $2.0 \mathrm{mmol})$ and $(E)-\beta$-methylstyrene (11, $355 \mathrm{mg}, 3.0 \mathrm{mmol})$. After purification by flash chromatography (PE-EtOAc, $80: 1 \rightarrow$ PE-EtOAc, $40: 1 \rightarrow$ PE-EtOAc, $20: 1)$, 48b (322 mg, $0.83 \mathrm{mmol}$, $41 \%)$ was isolated as a colorless oil. Prior to tosylation and chromatography, the ratio of the $\alpha$ - and the $\beta$-alkylated product was determined to be $1: 99 . \mathbf{4 8 b}:{ }^{1} \mathrm{H}$ NMR $\left(500 \mathrm{MHz}, \mathrm{CDCl}_{3}\right.$, TMS) $\delta=7.64(\mathrm{~d}, J=8.3 \mathrm{~Hz}, 2 \mathrm{H}), 7.30-7.25(\mathrm{~m}, 4 \mathrm{H}), 7.19(\mathrm{t}, J=$ $7.4 \mathrm{~Hz}, 1 \mathrm{H}), 7.13(\mathrm{~d}, J=7.1 \mathrm{~Hz}, 2 \mathrm{H}), 3.12-2.96(\mathrm{~m}, 3 \mathrm{H}), 2.92$ (dd, $J=13.7,8.0 \mathrm{~Hz}, 1 \mathrm{H}), 2.77(\mathrm{dd}, J=13.6,5.7 \mathrm{~Hz}, 1 \mathrm{H}), 2.41$ (s, 3H), $2.34(\mathrm{dd}, J=13.6,8.8 \mathrm{~Hz}, 1 \mathrm{H}), 2.12-2.01(\mathrm{~m}, 1 \mathrm{H})$, 1.51-1.40 (m, 2H), 1.30-1.15 (m, 6H), 0.89 (d, $J=6.6 \mathrm{~Hz}, 3 \mathrm{H})$, $0.87(\mathrm{t}, J=7.0 \mathrm{~Hz}, 3 \mathrm{H}) \mathrm{ppm} .{ }^{13} \mathrm{C}$ NMR $\left(125 \mathrm{MHz}, \mathrm{CDCl}_{3}\right) \delta=$ 142.9 (C), 140.4 (C), 136.7 (C), $129.5(\mathrm{CH}), 129.0(\mathrm{CH}), 128.2$ $(\mathrm{CH}), 127.2(\mathrm{CH}), 125.9(\mathrm{CH}), 54.6\left(\mathrm{CH}_{2}\right), 49.2\left(\mathrm{CH}_{2}\right), 40.9$ $\left(\mathrm{CH}_{2}\right), 34.3(\mathrm{CH}), 31.3\left(\mathrm{CH}_{2}\right), 28.4\left(\mathrm{CH}_{2}\right), 26.5\left(\mathrm{CH}_{2}\right), 22.5$ $\left(\mathrm{CH}_{2}\right), 21.5\left(\mathrm{CH}_{3}\right), 17.5\left(\mathrm{CH}_{3}\right), 14.0\left(\mathrm{CH}_{3}\right) \mathrm{ppm}$. IR (neat) $v_{\max }=$ $3027(\mathrm{~m}), 2928(\mathrm{~s}), 2870(\mathrm{~s}), 1599(\mathrm{~m}), 1495(\mathrm{~m}), 1455(\mathrm{~s}), 1340$ (s), $1161(\mathrm{~s}), 1191(\mathrm{~m}), 981(\mathrm{~m}), 815(\mathrm{~m}), 741(\mathrm{~s}), 701(\mathrm{~m}), 655$ (s) $\mathrm{cm}^{-1}$. MS (ESI+) $\mathrm{m} / z=410\left([\mathrm{M}+\mathrm{Na}]^{+}\right)$. HRMS (ESI +$) \mathrm{m} / \mathrm{z}$ calcd for $\mathrm{C}_{23} \mathrm{H}_{33} \mathrm{NO}_{2} \mathrm{SNa} 410.2130\left([\mathrm{M}+\mathrm{Na}]^{+}\right)$, found 410.2126.

(E)- $N$-(2-Methyl-4-phenylbut-3-en-1-yl)- $N$-phenylacetamide (60a) and (E)- $N$-phenyl- $N$-(5-phenylpent-4-en-1-yl)acetamide (60b). General procedure $C$ was used to synthesize 60a and 60b from $N$-methylaniline $(2,214 \mathrm{mg}, 2.0 \mathrm{mmol})$ and $(E)$-1phenyl-1,3-butadiene $(\mathbf{4 9}, 391 \mathrm{mg}, 3.0 \mathrm{mmol})$. Purification by flash column chromatography gave three fractions as oils. Fraction 1 contained pure compound $60 \mathrm{a}(151 \mathrm{mg}, 0.54 \mathrm{mmol}$, $27 \%$ ) and fraction 2 contained a mixture of $60 \mathrm{a}$ and $60 \mathrm{~b}$
(115 mg, $0.41 \mathrm{mg}, 21 \%$ ). Fraction 3 contained pure compound $60 \mathrm{~b}(140 \mathrm{mg}, 0.50 \mathrm{mmol}, 25 \%)$. Prior to acetylation and chromatography, the ratio of the branched and the linear product was determined to be $55: 45$. 60a: $R_{\mathrm{f}}=0.16$ (PE-MTBE, 2:1). ${ }^{1} \mathrm{H}$ NMR $\left(500 \mathrm{MHz}, \mathrm{CDCl}_{3}\right) \delta=7.39(\mathrm{t}, J=7.5 \mathrm{~Hz}, 2 \mathrm{H})$, 7.35-7.27 (m, 5H), 7.22-7.20 (m, 1H), $7.17(\mathrm{~d}, J=7.4 \mathrm{~Hz}, 2 \mathrm{H})$, $6.37(\mathrm{~d}, J=15.8 \mathrm{~Hz}, 1 \mathrm{H}), 6.06(\mathrm{dd}, J=15.8,8.5 \mathrm{~Hz}, 1 \mathrm{H}), 3.80$ (dd, $J=13.5,8.8 \mathrm{~Hz}, 1 \mathrm{H}), 3.73(\mathrm{dd}, J=13.5,6.5 \mathrm{~Hz}, 1 \mathrm{H}), 2.62$ (hept, $J=6.9 \mathrm{~Hz}, 1 \mathrm{H}), 1.81(\mathrm{~s}, 3 \mathrm{H}), 1.08(\mathrm{~d}, J=6.8 \mathrm{~Hz}, 3 \mathrm{H})$ ppm. ${ }^{13} \mathrm{C}$ NMR $\left(125 \mathrm{MHz}, \mathrm{CDCl}_{3}\right) \delta=170.6$ (C), 143.4 (C), 137.5 (C), $133.9(\mathrm{CH}), 129.9(\mathrm{CH}), 129.6(\mathrm{CH}), 128.5(\mathrm{CH}), 128.3(\mathrm{CH})$, $127.7(\mathrm{CH}), 127.0(\mathrm{CH}), 126.1(\mathrm{CH}), 54.5\left(\mathrm{CH}_{2}\right), 36.6(\mathrm{CH}), 22.8$ $\left(\mathrm{CH}_{3}\right), 18.4\left(\mathrm{CH}_{3}\right)$ ppm. IR (ATR) $v_{\max }=3057(\mathrm{w}), 3025(\mathrm{w})$, $2967(\mathrm{w}), 2927(\mathrm{w}), 2871(\mathrm{w}), 1656(\mathrm{vs}), 1594(\mathrm{~m}), 1494(\mathrm{~s}), 1394$ (s), 1292 (m), 1277 (m), 966 (m), 749 (s), 695 (vs) cm ${ }^{-1}$. MS (ESI +$) \mathrm{m} / z=302\left([\mathrm{M}+\mathrm{Na}]^{+}\right)$. HRMS (ESI +$) \mathrm{m} / z$ calcd for $\mathrm{C}_{19} \mathrm{H}_{21} \mathrm{NONa} 302.1521\left([\mathrm{M}+\mathrm{Na}]^{+}\right)$, found 302.1514. 60b: $R_{\mathrm{f}}=$ 0.11 (PE-MTBE, $2: 1) .{ }^{1} \mathrm{H}$ NMR $\left(500 \mathrm{MHz}, \mathrm{CDCl}_{3}\right) \delta=7.43(\mathrm{t}$, $J=7.6 \mathrm{~Hz}, 2 \mathrm{H}), 7.35(\mathrm{t}, J=7.4 \mathrm{~Hz}, 1 \mathrm{H}), 7.31-7.25(\mathrm{~m}, 4 \mathrm{H})$, 7.19-7.15 (m, 3H), $6.33(\mathrm{~d}, J=15.8 \mathrm{~Hz}, 1 \mathrm{H}), 6.16(\mathrm{dt}, J=15.8$, $6.8 \mathrm{~Hz}, 1 \mathrm{H}), 3.78-3.73(\mathrm{~m}, 2 \mathrm{H}), 2.25-2.18(\mathrm{~m}, 2 \mathrm{H}), 1.84(\mathrm{~s}, 3 \mathrm{H})$, 1.70 (pent, $J=7.6 \mathrm{~Hz}, 2 \mathrm{H}) \mathrm{ppm} .{ }^{13} \mathrm{C}$ NMR $\left(125 \mathrm{MHz}, \mathrm{CDCl}_{3}\right)$ $\delta=170.3(\mathrm{C}), 143.1(\mathrm{C}), 137.6(\mathrm{C}), 130.3(\mathrm{CH}), 129.7(\mathrm{CH}), 129.6$ $(\mathrm{CH}), 128.4(\mathrm{CH}), 128.1(\mathrm{CH}), 127.8(\mathrm{CH}), 126.9(\mathrm{CH}), 125.9$ $(\mathrm{CH}), 48.7\left(\mathrm{CH}_{2}\right), 30.3\left(\mathrm{CH}_{2}\right), 27.4\left(\mathrm{CH}_{2}\right), 22.8\left(\mathrm{CH}_{3}\right)$. IR (ATR) $v_{\max }=3060(\mathrm{w}), 3027(\mathrm{w}), 2931(\mathrm{w}), 2860(\mathrm{w}), 1655(\mathrm{vs}), 1596(\mathrm{~m})$, 1496 (s), 1397 (s), 1296 (m), 1280 (m), 968 (m), 744 (m), 698 (vs) $\mathrm{cm}^{-1}$. MS (ESI +$) \mathrm{m} / z=302\left([\mathrm{M}+\mathrm{Na}]^{+}\right.$). HRMS (ESI +$) \mathrm{m} / z$ calcd for $\mathrm{C}_{19} \mathrm{H}_{21} \mathrm{NONa}$ 302.1521 $\left([\mathrm{M}+\mathrm{Na}]^{+}\right)$, found 302.1511.

(E)- $N$-(2-Methyl-4-phenylbut-3-en-1-yl)- $N$-(4-phenoxyphenyl)acetamide (61a) and (E)- $N$-(4-phenoxyphenyl)- $N$-(5-phenylpent4-en-1-yl)acetamide (61b). General procedure $\mathrm{C}$ was used to synthesize 61a and 61b from para-phenoxy- $N$-methylaniline (34, $399 \mathrm{mg}, 2.0 \mathrm{mmol})$ and (E)-1-phenyl-1,3-butadiene (49, $391 \mathrm{mg}, 3.0 \mathrm{mmol})$. Purification by flash column chromatography (PE-MTBE, $2: 1$ ) gave three fractions as oils. Fraction 1 contained pure compound 61a (62 $\mathrm{mg}, 0.17 \mathrm{mmol}, 8 \%$ ) and fraction 2 contained a mixture of $61 \mathrm{a}$ and $\mathbf{6 1 b}(198 \mathrm{mg}$, $0.53 \mathrm{mmol}, 27 \%)$. Fraction 3 contained pure compound 61b (74 mg, $0.20 \mathrm{mmol}, 10 \%$ ). Prior to acetylation and chromatography, the ratio of the branched and the linear product was determined to be $54: 46$. 61a: $R_{\mathrm{f}}=0.22(\mathrm{PE}-\mathrm{MTBE}, 2: 1) .{ }^{1} \mathrm{H}$ NMR (500 MHz, $\left.\mathrm{CDCl}_{3}\right) \delta=7.40-7.35(\mathrm{~m}, 2 \mathrm{H}), 7.33-7.27(\mathrm{~m}$, $4 \mathrm{H}$ ), 7.22-7.14 (m, 2H), 7.11 (br. d, $J=8.8 \mathrm{~Hz}, 2 \mathrm{H}), 7.05$ (br. d, $J=7.7 \mathrm{~Hz}, 2 \mathrm{H}), 6.99$ (br. d, $J=8.8 \mathrm{~Hz}, 2 \mathrm{H}), 6.38(\mathrm{~d}, J=15.9 \mathrm{~Hz}$, $1 \mathrm{H}), 6.07$ (dd, $J=15.9,8.5 \mathrm{~Hz}, 1 \mathrm{H}), 3.78(\mathrm{dd}, J=13.4,8.9 \mathrm{~Hz}$, $1 \mathrm{H}), 3.72(\mathrm{dd}, J=13.4,6.4 \mathrm{~Hz}, 1 \mathrm{H}), 2.70-2.60(\mathrm{~m}, 1 \mathrm{H}), 1.84(\mathrm{~s}$, $3 \mathrm{H}), 1.10(\mathrm{~d}, J=6.8 \mathrm{~Hz}, 3 \mathrm{H}) \mathrm{ppm} .{ }^{13} \mathrm{C}$ NMR $\left(125 \mathrm{MHz}, \mathrm{CDCl}_{3}\right) \delta$ $=170.7$ (C), 156.8 (C), 156.3 (C), 138.1 (C), 137.4 (C), 133.9 $(\mathrm{CH}), 129.9(\mathrm{CH}), 129.9(\mathrm{CH}), 129.5(\mathrm{CH}), 128.5(\mathrm{CH}), 127.0$ $(\mathrm{CH}), 126.1(\mathrm{CH}), 124.0(\mathrm{CH}), 119.4(\mathrm{CH}), 119.0(\mathrm{CH}), 54.5$ $\left(\mathrm{CH}_{2}\right), 36.6(\mathrm{CH}), 22.8\left(\mathrm{CH}_{3}\right), 18.4\left(\mathrm{CH}_{3}\right)$ ppm. IR (ATR) $v_{\max }=$ $3059(\mathrm{w}), 3025(\mathrm{w}), 2964(\mathrm{w}), 2926(\mathrm{w}), 2869(\mathrm{w}), 1656(\mathrm{vs}), 1588$ (m), 1504 (s), 1488 (vs), 1393 (m), 1234 (vs), 967 (m), 870 (m), $844(\mathrm{~m}), 749(\mathrm{~s}), 692(\mathrm{~s}) \mathrm{cm}^{-1}$. MS (ESI +$) \mathrm{m} / z=372\left([\mathrm{M}+\mathrm{H}]^{+}\right)$. HRMS (ESI + ) $m / z$ calcd for $\mathrm{C}_{25} \mathrm{H}_{25} \mathrm{NO}_{2} \mathrm{Na} 394.1783\left([\mathrm{M}+\mathrm{Na}]^{+}\right)$, 
found 394.1787. 61b: $R_{\mathrm{f}}=0.14(\mathrm{PE}-\mathrm{MTBE}, 2: 1) .{ }^{1} \mathrm{H}$ NMR $\left(500 \mathrm{MHz}, \mathrm{CDCl}_{3}\right) \delta=7.41-7.36(\mathrm{~m}, 2 \mathrm{H}), 7.34-7.26(\mathrm{~m}, 4 \mathrm{H})$, $7.21-7.15$ (m, 2H), 7.12 (br. d, $J=8.8 \mathrm{~Hz}, 2 \mathrm{H}$ ), 7.07 (br. d, $J=$ $7.7 \mathrm{~Hz}, 2 \mathrm{H}$ ), 7.02 (br. d, $J=8.8 \mathrm{~Hz}, 2 \mathrm{H}$ ), 6.36 (d, $J=15.9 \mathrm{~Hz}$, $1 \mathrm{H}), 6.19(\mathrm{dt}, J=15.9,6.9 \mathrm{~Hz}, 1 \mathrm{H}), 3.76-3.71(\mathrm{~m}, 2 \mathrm{H}), 2.24(\mathrm{q}$, $J=7.4 \mathrm{~Hz}, 2 \mathrm{H}$ ), 1.87 (s, 3H), 1.72 (pent, $J=7.6 \mathrm{~Hz}, 2 \mathrm{H}$ ) ppm. ${ }^{13} \mathrm{C} \mathrm{NMR}\left(125 \mathrm{MHz}, \mathrm{CDCl}_{3}\right) \delta=170.3$ (C), 157.0 (C), 156.2 (C), $137.8(\mathrm{C}), 137.5(\mathrm{C}), 130.3(\mathrm{CH}), 129.9(\mathrm{CH}), 129.6(\mathrm{CH}), 129.3$ $(\mathrm{CH}), 128.4(\mathrm{CH}), 126.8(\mathrm{CH}), 125.9(\mathrm{CH}), 124.0(\mathrm{CH}), 119.4$ $(\mathrm{CH}), 119.1(\mathrm{CH}), 48.7\left(\mathrm{CH}_{2}\right), 30.2\left(\mathrm{CH}_{2}\right), 27.4\left(\mathrm{CH}_{2}\right), 22.8\left(\mathrm{CH}_{3}\right)$ ppm. IR (ATR) $v_{\max }=3062(\mathrm{w}), 3028(\mathrm{w}), 2926(\mathrm{w}), 2851(\mathrm{w})$, 1658 (s), 1506 (s), 1489 (s), 1397 (m), 1294 (m), 1233 (vs), 968 (m), $750(\mathrm{~m}), 693(\mathrm{~s}) \mathrm{cm}^{-1}$. MS (ESI+) $m / z=372\left([\mathrm{M}+\mathrm{H}]^{+}\right)$. HRMS (ESI + ) $m / z$ calcd for $\mathrm{C}_{25} \mathrm{H}_{25} \mathrm{NO}_{2} \mathrm{Na} 394.1783\left([\mathrm{M}+\mathrm{Na}]^{+}\right)$, found 394.1778.

(E)- $N$-(4-Methoxyphenyl)- $N$-(2-methyl-4-phenylbut-3-en-1-yl)acetamide $(62 \mathrm{a})^{7 h}$ and $(E)-N-(4-m e t h o x y p h e n y l)-N$-(5-phenylpent-4-en-1-yl)acetamide $(62 \mathrm{~b}){ }^{7 \boldsymbol{h}}$ General procedure $\mathrm{C}$ was used to synthesize 62a and 62b from para-methoxy- $N$-methylaniline $(\mathbf{5 5}, 274 \mathrm{mg}, 2.0 \mathrm{mmol})$ and $(E)$-1-phenyl-1,3-butadiene (49, $391 \mathrm{mg}, 3.0 \mathrm{mmol})$. Purification by flash column chromatography (PE-MTBE, 2:1) gave three fractions as oils. Fraction 1 contained pure compound 62a (82 mg, $0.27 \mathrm{mmol}$, $13 \%$ ) and fraction 2 contained a mixture of $62 \mathbf{a}$ and $62 \mathbf{b}$ (142 mg, $0.46 \mathrm{mmol}, 23 \%$ ). Fraction 3 contained pure compound $62 \mathrm{~b}$ ( $59 \mathrm{mg}, 0.19 \mathrm{mmol}, 10 \%)$. Prior to acetylation and chromatography, the ratio of the branched and the linear product was determined to be $54: 46$. 62a: $R_{\mathrm{f}}=0.24(\mathrm{PE}-$ MTBE, $2: 1) .{ }^{1} \mathrm{H}$ NMR (500 MHz, $\left.\mathrm{CDCl}_{3}\right) \delta=7.30-7.24(\mathrm{~m}, 4 \mathrm{H})$, 7.19-7.15 (m, 1H), 7.05 (br. d, $J=8.8 \mathrm{~Hz}, 2 \mathrm{H}$ ), 6.86 (br. d, $J=$ $8.8 \mathrm{~Hz}, 2 \mathrm{H}), 6.34(\mathrm{~d}, J=15.9 \mathrm{~Hz}, 1 \mathrm{H}), 6.04(\mathrm{dd}, J=15.8,8.4 \mathrm{~Hz}$, $1 \mathrm{H}), 3.79(\mathrm{~s}, 3 \mathrm{H}), 3.73(\mathrm{dd}, J=13.4,8.4 \mathrm{~Hz}, 1 \mathrm{H}), 3.66(\mathrm{dd}, J=$ 13.4, $6.5 \mathrm{~Hz}, 1 \mathrm{H}), 2.62-2.54(\mathrm{~m}, 1 \mathrm{H}), 1.77(\mathrm{~s}, 3 \mathrm{H}), 1.05(\mathrm{~d}, J=$ $6.8 \mathrm{~Hz}, 3 \mathrm{H}) \mathrm{ppm} .{ }^{13} \mathrm{C} \mathrm{NMR}\left(125 \mathrm{MHz}, \mathrm{CDCl}_{3}\right) \delta=170.9(\mathrm{C})$, 158.7 (C), 137.5 (C), 136.1 (C), 133.9 (CH), 129.8 (CH), 129.2 $(\mathrm{CH}), 128.4(\mathrm{CH}), 127.0(\mathrm{CH}), 126.1(\mathrm{CH}), 114.6(\mathrm{CH}), 55.4$ $\left(\mathrm{CH}_{3}\right), 54.5\left(\mathrm{CH}_{2}\right), 36.5(\mathrm{CH}), 22.7\left(\mathrm{CH}_{3}\right), 18.3\left(\mathrm{CH}_{3}\right)$ ppm. 62b: $R_{\mathrm{f}}=0.21$ (PE-MTBE, $\left.2: 1\right) .{ }^{1} \mathrm{H}$ NMR $\left(500 \mathrm{MHz}, \mathrm{CDCl}_{3}\right) \delta=$ $7.32-7.24$ (m, 4H), 7.19-7.15 (m, 1H), 7.08 (br. d, $J=8.9 \mathrm{~Hz}$, 2H), 6.92 (br. d, $J=8.9 \mathrm{~Hz}, 2 \mathrm{H}), 6.33$ (d, $J=15.8 \mathrm{~Hz}, 1 \mathrm{H}), 6.16$ (dt, $J=15.8,6.9 \mathrm{~Hz}, 1 \mathrm{H}), 3.83(\mathrm{~s}, 3 \mathrm{H}), 3.73-3.69(\mathrm{~m}, 2 \mathrm{H}), 2.21$ (q, $J=7.6 \mathrm{~Hz}, 2 \mathrm{H}), 1.82(\mathrm{~s}, 3 \mathrm{H}), 1.68$ (pent, $J=7.6 \mathrm{~Hz}, 2 \mathrm{H}$ ) ppm. ${ }^{13} \mathrm{C}$ NMR (125 MHz, $\mathrm{CDCl}_{3}$ ) $\delta=170.6$ (C), 158.9 (C), 137.6 (C), $135.8(\mathrm{C}), 130.2(\mathrm{CH}), 129.7(\mathrm{CH}), 129.1(\mathrm{CH}), 128.4(\mathrm{CH})$, $126.9(\mathrm{CH}), 125.9(\mathrm{CH}), 114.7(\mathrm{CH}), 55.4\left(\mathrm{CH}_{3}\right), 48.7\left(\mathrm{CH}_{2}\right), 30.3$ $\left(\mathrm{CH}_{2}\right), 27.4\left(\mathrm{CH}_{2}\right), 22.8\left(\mathrm{CH}_{3}\right)$ ppm.

$(E)-N$-(2-Methyl-4-phenylbut-3-en-1-yl)- $N$-(4-(trifluoromethoxy)phenyl)acetamide (63a) and (E)- $N$-(5-phenylpent-4-en-1-yl)- $N-(4-$ (trifluoromethoxy)phenyl)-acetamide (63b). General procedure $\mathrm{C}$ was used to synthesize $\mathbf{6 3 \mathbf { a }}$ and $\mathbf{6 3 \mathbf { b }}$ from para-trifluoromethoxy- $N$-methylaniline (56, $382 \mathrm{mg}, 2.0 \mathrm{mmol}$ ), and (E)-1phenyl-1,3-butadiene (49, $391 \mathrm{mg}, 3.0 \mathrm{mmol})$. Purification by flash column chromatography (PE-MTBE, $1: 1)$ gave three fractions as oils. Fraction 1 contained pure compound 63a (76 mg, $0.21 \mathrm{mmol}, 11 \%$ ) and fraction 2 contained a mixture of $63 \mathrm{a}$ and 63b (412 mg, $1.14 \mathrm{mmol}, 57 \%$ ). Fraction 3 contained pure compound 63b (107 mg, $0.30 \mathrm{mmol}, 14 \%)$. Prior to acetylation and chromatography, the ratio of the branched and the linear product was determined to be $53: 47$. 63a: $R_{\mathrm{f}}=0.28(\mathrm{PE}-$ MTBE, $1: 1) .{ }^{1} \mathrm{H}$ NMR (500 MHz, $\left.\mathrm{CDCl}_{3}\right) \delta=7.31-7.27(\mathrm{~m}, 4 \mathrm{H})$, $7.24-7.17$ (m, 5H), 6.36 (d, $J=15.9 \mathrm{~Hz}, 1 \mathrm{H}), 6.01$ (dd, $J=15.8$, $8.6 \mathrm{~Hz}, 1 \mathrm{H}), 3.79-3.70(\mathrm{~m}, 2 \mathrm{H}), 2.68-2.58(\mathrm{~m}, 1 \mathrm{H}), 1.82(\mathrm{~s}, 3 \mathrm{H})$, $1.08(\mathrm{~d}, J=6.8 \mathrm{~Hz}, 3 \mathrm{H}) \mathrm{ppm} .{ }^{13} \mathrm{C} \mathrm{NMR}\left(125 \mathrm{MHz}, \mathrm{CDCl}_{3}\right) \delta=$ 170.4 (C), 148.2 (C), 142.0 (C), 137.3 (C), $133.7(\mathrm{CH}), 130.2$ $(\mathrm{CH}), 129.8(\mathrm{CH}), 128.5(\mathrm{CH}), 127.2(\mathrm{CH}), 126.1(\mathrm{CH}), 122.0$ $(\mathrm{CH}), 120.4\left(\mathrm{q},{ }^{1} J_{\mathrm{C}, \mathrm{F}}=258.0 \mathrm{~Hz}, \mathrm{CF}_{3}\right), 154.7\left(\mathrm{CH}_{2}\right), 36.7(\mathrm{CH})$, $22.8\left(\mathrm{CH}_{3}\right), 18.4\left(\mathrm{CH}_{3}\right)$ ppm. ${ }^{19} \mathrm{~F}$ NMR $\left(500 \mathrm{MHz}, \mathrm{CDCl}_{3}\right) \delta=$ $-58.0 \mathrm{ppm}$. IR (ATR) $v_{\max }=3061(\mathrm{w}), 3026(\mathrm{w}), 2965(\mathrm{w}), 2929$ (w), 2872 (w), 1662 (s), 1506 (s), 1392 (m) 1252 (vs), 1198 (vs),

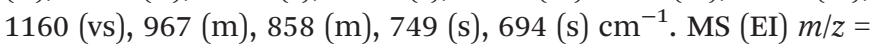
$363\left([\mathrm{M}]^{+}\right)$. HRMS (EI) $\mathrm{m} / \mathrm{z}$ calcd for $\mathrm{C}_{20} \mathrm{H}_{20} \mathrm{O}_{2} \mathrm{NF}_{3} 363.1441$ $\left([\mathrm{M}]^{+}\right)$, found 363.1449. 63b: $R_{\mathrm{f}}=0.20(\mathrm{PE}-\mathrm{MTBE}, 1: 1) \cdot{ }^{1} \mathrm{H}$ NMR (500 MHz, $\left.\mathrm{CDCl}_{3}\right) \delta=7.30-7.26(\mathrm{~m}, 5 \mathrm{H}), 7.23-7.17(\mathrm{~m}$, $4 \mathrm{H}), 6.34(\mathrm{~d}, J=15.9 \mathrm{~Hz}, 1 \mathrm{H}), 6.15(\mathrm{dt}, J=15.7,6.8 \mathrm{~Hz}, 1 \mathrm{H})$, 3.78-3.71 (m, 2H), 2.25-2.18 (m, 2H), 1.84 (s, 3H), 1.70 (pent, $J=7.5 \mathrm{~Hz}, 2 \mathrm{H}) \mathrm{ppm} .{ }^{13} \mathrm{C} \mathrm{NMR}\left(125 \mathrm{MHz}, \mathrm{CDCl}_{3}\right) \delta=170.0(\mathrm{C})$, 148.4 (C), 141.7 (C), 137.5 (C), $130.5(\mathrm{CH}), 129.6(\mathrm{CH}), 129.4$ $(\mathrm{CH}), 128.5(\mathrm{CH}), 127.0(\mathrm{CH}), 126.0(\mathrm{CH}), 122.1(\mathrm{CH}), 120.4(\mathrm{q}$, $\left.{ }^{1} J_{\mathrm{C}, \mathrm{F}}=258.0 \mathrm{~Hz}, \mathrm{CF}_{3}\right), 48.8\left(\mathrm{CH}_{2}\right), 30.3\left(\mathrm{CH}_{2}\right), 27.5\left(\mathrm{CH}_{2}\right), 22.8$ $\left(\mathrm{CH}_{3}\right)$ ppm. ${ }^{19} \mathrm{~F}$ NMR $\left(500 \mathrm{MHz}, \mathrm{CDCl}_{3}\right) \delta=-58.0 \mathrm{ppm}$. IR (ATR) $v_{\max }=3063(\mathrm{w}), 3027(\mathrm{w}), 2931(\mathrm{w}), 2866(\mathrm{w}), 1660(\mathrm{~s})$, 1506 (s), 1448 (m), 1396 (m), 1252 (vs), 1203 (vs), 1161 (vs), 967 (m), $857(\mathrm{~m}), 747(\mathrm{~m}), 695(\mathrm{~m}) \mathrm{cm}^{-1}$. MS (EI) m/z=363 ([M] $\left.]^{+}\right)$. HRMS (EI) $m / z$ calcd for $\mathrm{C}_{20} \mathrm{H}_{20} \mathrm{O}_{2} \mathrm{NF}_{3} 363.1441$ ([M]+), found 363.1444 .

(E)-N-(2-Methyl-4-phenylbut-3-en-1-yl)- $N$-(4-(methylthio)-phenyl)acetamide (64a) and (E)-N-(4-(methylthio)phenyl)- $N$-(5-phenylpent-4-en-1-yl)acetamide (64b). General procedure $\mathrm{C}$ was used to synthesize $64 \mathrm{a}$ and $\mathbf{6 4 b}$ from para-thiomethyl- $N$-methylaniline $(\mathbf{5 7}, 306 \mathrm{mg}, 2.0 \mathrm{mmol})$ and (E)-1-phenyl-1,3-butadiene (49, $391 \mathrm{mg}, 3.0 \mathrm{mmol})$. Purification by flash column chromatography (PE-MTBE, $1.5: 1$ ) gave three fractions as oils. Fraction 1 contained pure compound 64a (123 mg, $0.38 \mathrm{mmol}$, $19 \%$ ) and fraction 2 contained a mixture of $64 a$ and $64 \mathrm{~b}$ (149 mg, $0.46 \mathrm{mmol}, 23 \%$ ). Fraction 3 contained pure compound $64 \mathrm{~b}$ (73 mg, $0.23 \mathrm{mmol}, 11 \%$ ). Prior to acetylation and chromatography, the ratio of the branched and the linear product was determined to be $54: 46.64 \mathrm{a}:{ }^{1} \mathrm{H}$ NMR $(500 \mathrm{MHz}$, $\left.\mathrm{CDCl}_{3}\right) \delta=7.31-7.28(\mathrm{~m}, 4 \mathrm{H}), 7.23$ (br. d, $J=8.5 \mathrm{~Hz}, 2 \mathrm{H}$ ), 7.21-7.18 (m, 1H), 7.07 (br. d, $J=8.5 \mathrm{~Hz}, 2 \mathrm{H}$ ), 6.35 (d, $J=15.8$ $\mathrm{Hz}, 1 \mathrm{H}), 6.04$ (dd, $J=15.9,8.5 \mathrm{~Hz}, 1 \mathrm{H}), 3.76(\mathrm{dd}, J=13.4,8.8$ $\mathrm{Hz}, 1 \mathrm{H}), 3.70$ (dd, $J=13.4,6.5 \mathrm{~Hz}, 1 \mathrm{H}), 2.64-2.57$ (m, 1H), 2.49 $(\mathrm{s}, 3 \mathrm{H}), 1.81(\mathrm{~s}, 3 \mathrm{H}), 1.07$ (d, $J=6.8 \mathrm{~Hz}, 3 \mathrm{H}) \mathrm{ppm} .{ }^{13} \mathrm{C} \mathrm{NMR}$ $\left(125 \mathrm{MHz}, \mathrm{CDCl}_{3}\right) \delta=170.6$ (C), 140.2 (C), 138.4 (C), 137.4 (C), $133.8(\mathrm{CH}), 129.9(\mathrm{CH}), 128.6(\mathrm{CH}), 128.5(\mathrm{CH}), 127.1(\mathrm{CH})$, $126.1(\mathrm{CH}), 54.4\left(\mathrm{CH}_{2}\right), 36.6(\mathrm{CH}), 22.8\left(\mathrm{CH}_{3}\right), 18.4\left(\mathrm{CH}_{3}\right), 15.6$ $\left(\mathrm{CH}_{3}\right)$ ppm. IR (ATR) $v_{\max }=3025(\mathrm{w}), 2963(\mathrm{w}), 2921(\mathrm{~m}), 2851$ (w), 1656 (vs), 1492 (vs), 1391 (s), 1286 (m), 1098 (m), 966 (s), $829(\mathrm{~m}), 747(\mathrm{~s}), 694(\mathrm{~s}) \mathrm{cm}^{-1}$. MS (ESI +$) \mathrm{m} / z=348\left([\mathrm{M}+\mathrm{Na}]^{+}\right)$. HRMS (ESI + ) $m / z$ calcd for $\mathrm{C}_{20} \mathrm{H}_{23}$ NOSNa $348.1398\left([\mathrm{M}+\mathrm{Na}]^{+}\right)$, found 348.1401. 64b: ${ }^{1} \mathrm{H} \mathrm{NMR}\left(500 \mathrm{MHz}, \mathrm{CDCl}_{3}\right) \delta=7.24-7.18$ (m, 6H), 7.13-7.09 (m, 1H), 7.01 (br. d, $J=8.4 \mathrm{~Hz}, 2 \mathrm{H}), 6.25$ 
(d, $J=15.7 \mathrm{~Hz}, 1 \mathrm{H}), 6.08(\mathrm{dt}, J=15.8,6.9 \mathrm{~Hz}, 1 \mathrm{H}), 3.68-3.62$ $(\mathrm{m}, 2 \mathrm{H}), 2.43(\mathrm{~s}, 3 \mathrm{H}), 2.17-2.11(\mathrm{~m}, 2 \mathrm{H}), 1.77(\mathrm{~s}, 3 \mathrm{H}), 1.61$ (pent, $J=7.6 \mathrm{~Hz}, 2 \mathrm{H}) \mathrm{ppm} .{ }^{13} \mathrm{C}$ NMR $\left(125 \mathrm{MHz}, \mathrm{CDCl}_{3}\right) \delta=$ 170.3 (C), 139.9 (C), 138.6 (C), 137.5 (C), 130.3 (CH), 129.6 $(\mathrm{CH}), 128.5(\mathrm{CH}), 128.4(\mathrm{CH}), 127.2(\mathrm{CH}), 126.9(\mathrm{CH}), 125.9$ $(\mathrm{CH}), 48.6\left(\mathrm{CH}_{2}\right), 30.3\left(\mathrm{CH}_{2}\right), 27.4\left(\mathrm{CH}_{2}\right), 22.8\left(\mathrm{CH}_{3}\right), 15.6\left(\mathrm{CH}_{3}\right)$ ppm. IR (ATR) $v_{\max }=3024(\mathrm{w}), 2920(\mathrm{~m}), 2851$ (w), 1654 (vs), 1492 (s), 1438 (m), 1392 (s), 1291 (m), 1098 (m), 966 (s), 828 (m), $747(\mathrm{~m}), 693(\mathrm{~s}) \mathrm{cm}^{-1}$. MS (ESI+) $\mathrm{m} / z=348\left([\mathrm{M}+\mathrm{Na}]^{+}\right)$. HRMS (ESI + ) $m / z$ calcd for $\mathrm{C}_{20} \mathrm{H}_{23} \mathrm{NOSNa} 348.1398\left([\mathrm{M}+\mathrm{Na}]^{+}\right)$, found 348.1397.

(E)- $N$-(4-Isopropylphenyl)- $N$-(2-methyl-4-phenylbut-3-en-1-yl)acetamide (65a) and (E)-N-(4-isopropylphenyl)- $N$-(5-phenylpent-4-en-1-yl)acetamide (65b). General procedure $C$ was used to synthesize 65a and $\mathbf{6 5 b}$ from para-isopropyl- $N$-methylaniline (58, $299 \mathrm{mg}, 2.0 \mathrm{mmol})$ and (E)-1-phenyl-1,3-butadiene (49, $391 \mathrm{mg}, 3.0 \mathrm{mmol}$ ). Purification by flash column chromatography (PE-MTBE, $1.5: 1$ ) gave three fractions as oils. Fraction 1 contained pure compound $65 \mathrm{a}$ (74 $\mathrm{mg}, 0.23 \mathrm{mmol}, 12 \%$ ) and fraction 2 contained a mixture of $65 \mathbf{a}$ and $65 \mathbf{b}(278 \mathrm{mg}$, $0.87 \mathrm{mmol}, 43 \%)$. Fraction 3 contained pure compound 65b (61 mg, $0.19 \mathrm{mmol}, 9 \%$ ). Prior to acetylation and chromatography, the ratio of the branched and the linear product was determined to be $53: 47$. 65a: ${ }^{1} \mathrm{H}$ NMR (500 MHz, $\left.\mathrm{CDCl}_{3}\right) \delta=$ 7.31-7.27 (m, 4H), $7.22(\mathrm{~d}, J=8.3 \mathrm{~Hz}, 2 \mathrm{H}), 7.21-7.18(\mathrm{~m}, 1 \mathrm{H})$, $7.07(\mathrm{~d}, J=8.3 \mathrm{~Hz}, 2 \mathrm{H}), 6.36(\mathrm{~d}, J=15.9 \mathrm{~Hz}, 1 \mathrm{H}), 6.06(\mathrm{dd}, J=$ 15.8, 8.4 Hz, 1H), $3.77(\mathrm{dd}, J=13.4,8.7 \mathrm{~Hz}, 1 \mathrm{H}), 3.71(\mathrm{dd}, J=$ 13.4, $6.5 \mathrm{~Hz}, 1 \mathrm{H}$ ), 2.93 (hept, $J=6.9 \mathrm{~Hz}, 1 \mathrm{H}), 2.67-2.58$ (m, $1 \mathrm{H}), 1.81(\mathrm{~s}, 3 \mathrm{H}), 1.26(\mathrm{~d}, J=6.9 \mathrm{~Hz}, 6 \mathrm{H}), 1.08(\mathrm{~d}, J=6.8 \mathrm{~Hz}$, $3 \mathrm{H}) \mathrm{ppm} .{ }^{13} \mathrm{C}$ NMR $\left(125 \mathrm{MHz}, \mathrm{CDCl}_{3}\right) \delta=170.8$ (C), 148.4 (C), 140.9 (C), $137.6(\mathrm{C}), 134.0(\mathrm{CH}), 129.7(\mathrm{CH}), 128.4(\mathrm{CH}), 128.0$ $(\mathrm{CH}), 127.4(\mathrm{CH}), 127.0(\mathrm{CH}), 126.1(\mathrm{CH}), 54.4\left(\mathrm{CH}_{2}\right), 36.5$ $(\mathrm{CH}), 33.7(\mathrm{CH}), 23.9\left(\mathrm{CH}_{3}\right), 22.9\left(\mathrm{CH}_{3}\right), 18.3\left(\mathrm{CH}_{3}\right)$ ppm. IR (ATR) $v_{\max }=3027(\mathrm{w}), 2963(\mathrm{~m}), 2929(\mathrm{w}), 2872(\mathrm{w}), 1658(\mathrm{vs})$, 1511 (s), 1395 (s), 1289 (m), 1215 (w), 968 (m), 845 (m), 749 (s), $696(\mathrm{~s}) \mathrm{cm}^{-1}$. MS (ESI+) $\mathrm{m} / z=344\left([\mathrm{M}+\mathrm{Na}]^{+}\right)$. HRMS (ESI+) $\mathrm{m} / z$ calcd for $\mathrm{C}_{22} \mathrm{H}_{27} \mathrm{NONa} 344.1990\left([\mathrm{M}+\mathrm{Na}]^{+}\right)$, found 344.1982. 65b: ${ }^{1} \mathrm{H}$ NMR (500 MHz, $\left.\mathrm{CDCl}_{3}\right) \delta=7.31-7.24(\mathrm{~m}, 7 \mathrm{H}), 7.07$ (d, $J=8.3 \mathrm{~Hz}, 2 \mathrm{H}), 6.33(\mathrm{~d}, J=15.9 \mathrm{~Hz}, 1 \mathrm{H}), 6.16(\mathrm{dt}, J=15.8,6.8$ $\mathrm{Hz}, 1 \mathrm{H}), 3.75-3.71(\mathrm{~m}, 2 \mathrm{H}), 2.94$ (hept, $J=7.0 \mathrm{~Hz}, 1 \mathrm{H}$ ), 2.24-2.18 (m, 2H), 1.83 (s, 3H), 1.70 (pent, $J=7.6 \mathrm{~Hz}, 2 \mathrm{H}$ ), 1.27 $(\mathrm{d}, J=6.9 \mathrm{~Hz}, 6 \mathrm{H}) \mathrm{ppm} .{ }^{13} \mathrm{C} \mathrm{NMR}\left(125 \mathrm{MHz}, \mathrm{CDCl}_{3}\right) \delta=170.5$ (C), 148.6 (C), 140.7 (C), 137.6 (C), $130.2(\mathrm{CH}), 129.8(\mathrm{CH})$, $128.4(\mathrm{CH}), 127.8(\mathrm{CH}), 127.6(\mathrm{CH}), 126.9(\mathrm{CH}), 125.9(\mathrm{CH})$, $48.7\left(\mathrm{CH}_{2}\right), 33.7(\mathrm{CH}), 30.3\left(\mathrm{CH}_{2}\right), 27.4\left(\mathrm{CH}_{2}\right), 23.9\left(\mathrm{CH}_{3}\right), 22.8$ $\left(\mathrm{CH}_{3}\right)$ ppm. IR (ATR) $v_{\max }=3028(\mathrm{w}), 2962(\mathrm{~m}), 2930(\mathrm{w}), 2872$ (w), 1658 (vs), 1511 (s), 1397 (s), 1294 (m), 968 (m), 845 (m), $749(\mathrm{~m}), 696(\mathrm{~s}) \mathrm{cm}^{-1}$. MS (ESI +$) \mathrm{m} / z=344\left([\mathrm{M}+\mathrm{Na}]^{+}\right)$. HRMS (ESI+) $m / z$ calcd for $\mathrm{C}_{22} \mathrm{H}_{28} \mathrm{NO} 322.2165\left([\mathrm{M}+\mathrm{H}]^{+}\right)$, found 322.2168 .

(E)-N-(4-Chlorophenyl)- $N$-(2-methyl-4-phenylbut-3-en-1-yl)-

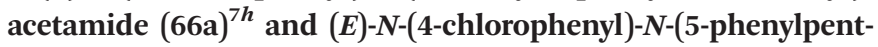
4-en-1-yl)acetamide (66b). General procedure $\mathrm{C}$ was used to synthesize 66a and 66b from para-chloro- $N$-methylaniline (59, $283 \mathrm{mg}, 2.0 \mathrm{mmol}$ ) and (E)-1-phenyl-1,3-butadiene (49, $391 \mathrm{mg}, 3.0 \mathrm{mmol}$ ). Purification by flash column chromato- graphy (PE-MTBE, 1:1) gave three fractions as oils. Fraction 1 contained pure compound 66a (111 mg, $0.36 \mathrm{mmol}, 18 \%$ ) and fraction 2 contained a mixture of $\mathbf{6 6 a}$ and $66 \mathbf{b}(206 \mathrm{mg}$, $0.66 \mathrm{mmol}, 33 \%$ ). Fraction 3 contained compound $\mathbf{6 6 b}$ ( $88 \mathrm{mg}$, $0.28 \mathrm{mmol}, 14 \%$ ) with trace impurities of 66a. Prior to acetylation and chromatography, the ratio of the branched and the linear product was determined to be $50: 50$. 66a: $R_{\mathrm{f}}=0.23(\mathrm{PE}-$ MTBE, $1: 1) .{ }^{1} \mathrm{H}$ NMR $\left(500 \mathrm{MHz}, \mathrm{CDCl}_{3}\right) \delta=7.36(\mathrm{~d}, J=8.6 \mathrm{~Hz}$, 2H), 7.32-7.28 (m, 4H), 7.24-7.19 (m, 1H), 7.10 (d, $J=8.5 \mathrm{~Hz}$, $2 \mathrm{H}), 6.35(\mathrm{~d}, J=15.9 \mathrm{~Hz}, 1 \mathrm{H}), 6.02(\mathrm{dd}, J=15.8,8.6 \mathrm{~Hz}, 1 \mathrm{H})$, $3.76(\mathrm{dd}, J=13.5,9.0 \mathrm{~Hz}, 1 \mathrm{H}), 3.70(\mathrm{dd}, J=13.5,6.4 \mathrm{~Hz}, 1 \mathrm{H})$, 2.65-2.56 (m, 1H), 1.81 (s, 3H), 1.07 (d, $J=6.7 \mathrm{~Hz}, 3 \mathrm{H}) \mathrm{ppm}$. ${ }^{13} \mathrm{C}$ NMR (125 MHz, $\mathrm{CDCl}_{3}$ ) $\delta=170.3$ (C), 141.9 (C), 137.3 (C), $133.6(\mathrm{CH}), 133.5(\mathrm{C}), 130.1(\mathrm{CH}), 129.8(\mathrm{CH}), 129.6(\mathrm{CH}), 128.5$ $(\mathrm{CH}), 127.2(\mathrm{CH}), 126.1(\mathrm{CH}), 54.5\left(\mathrm{CH}_{2}\right), 36.6(\mathrm{CH}), 22.8\left(\mathrm{CH}_{3}\right)$, $18.4\left(\mathrm{CH}_{3}\right)$ ppm. 66b: $R_{\mathrm{f}}=0.19(\mathrm{PE}-\mathrm{MTBE}, 1: 1) .{ }^{1} \mathrm{H} \mathrm{NMR}$ $\left(500 \mathrm{MHz}, \mathrm{CDCl}_{3}\right) \delta=7.36(\mathrm{~d}, J=8.6 \mathrm{~Hz}, 2 \mathrm{H}), 7.28-7.21(\mathrm{~m}$, $4 \mathrm{H}), 7.16-7.12(\mathrm{~m}, 1 \mathrm{H}), 7.07$ (d, $J=8.6 \mathrm{~Hz}, 2 \mathrm{H}), 6.29$ (d, $J=15.8$ $\mathrm{Hz}, 1 \mathrm{H}), 6.10(\mathrm{dt}, J=15.7,6.9 \mathrm{~Hz}, 1 \mathrm{H}), 3.71-3.66(\mathrm{~m}, 2 \mathrm{H})$, 2.20-2.14 (m, 2H), 1.80 (s, 3H), 1.63 (pent, $J=7.6 \mathrm{~Hz}, 2 \mathrm{H}$ ) ppm. ${ }^{13} \mathrm{C}$ NMR (125 MHz, $\mathrm{CDCl}_{3}$ ) $\delta=170.0$ (C), 141.6 (C), 137.5 (C), $133.7(\mathrm{C}), 130.4(\mathrm{CH}), 129.9(\mathrm{CH}), 129.4(\mathrm{CH}), 128.4(\mathrm{CH})$, $126.9(\mathrm{CH}), 125.9(\mathrm{CH}), 48.7\left(\mathrm{CH}_{2}\right), 30.2\left(\mathrm{CH}_{2}\right), 27.4\left(\mathrm{CH}_{2}\right), 22.8$ $\left(\mathrm{CH}_{3}\right)$ ppm. IR (ATR) $v_{\max }=3059(\mathrm{w}), 3025(\mathrm{w}), 2929(\mathrm{~m}), 2864$ (w), 1657 (vs), 1489 (vs), 1446 (m), 1392 (s), 1289 (m), 1091 (s), $1014(\mathrm{~m}), 966$ (s), $838(\mathrm{~m}), 746$ (s) $693(\mathrm{~s}) \mathrm{cm}^{-1}$. MS (ESI+) $\mathrm{m} / z=$ $336\left([\mathrm{M}+\mathrm{Na}]^{+}\right)$. HRMS (ESI +$) \mathrm{m} / z$ calcd for $\mathrm{C}_{19} \mathrm{H}_{20} \mathrm{NOCINa}$ $336.1131\left([\mathrm{M}+\mathrm{Na}]^{+}\right)$, found 336.1130.

(E)-N-(4-(4-Chlorophenyl)-2-methylbut-3-en-1-yl)- $N$-phenylacetamide (67a) and (E)- $\mathrm{N}$-(5-(4-chlorophenyl)pent-4-en-1-yl)$N$-phenylacetamide $(67 \mathrm{~b}){ }^{7 \boldsymbol{h}}$ General procedure C was used to synthesize 67a and 67b from $N$-methylaniline $(2,214 \mathrm{mg}$, $2.0 \mathrm{mmol}$ ) and (E)-1-(para-chlorophenyl)-1,3-butadiene (50, $494 \mathrm{mg}, 3.0 \mathrm{mmol}$ ). Purification by flash column chromatography (PE-MTBE, $2: 1$ ) gave three fractions as oils. Fraction 1 contained pure compound 67a (65 mg, $0.21 \mathrm{mmol}, 10 \%)$ and fraction 2 contained a mixture of $67 \mathbf{a}$ and $67 \mathbf{b}(150 \mathrm{mg}$, $0.48 \mathrm{mmol}, 25 \%)$. Fraction 3 contained pure compound $\mathbf{6 7} \mathbf{b}$ (109 mg, $0.35 \mathrm{mmol}, 17 \%$ ). Prior to acetylation and chromatography, the ratio of the branched and the linear product was determined to be $50: 50$. 67a: $R_{\mathrm{f}}=0.19(\mathrm{PE}-\mathrm{MTBE}, 2: 1) .{ }^{1} \mathrm{H}$ NMR (500 MHz, $\left.\mathrm{CDCl}_{3}\right) \delta=7.38(\mathrm{t}, J=7.6 \mathrm{~Hz}, 2 \mathrm{H}), 7.32(\mathrm{t}, J=$ $7.4 \mathrm{~Hz}, 1 \mathrm{H}), 7.25-7.19(\mathrm{~m}, 4 \mathrm{H}), 7.14$ (d, $J=7.7 \mathrm{~Hz}, 2 \mathrm{H}), 6.31$ (d, $J=15.9 \mathrm{~Hz}, 1 \mathrm{H}), 6.03(\mathrm{dd}, J=15.8,8.4 \mathrm{~Hz}, 1 \mathrm{H}), 3.79(\mathrm{dd}, J=$ $13.5,8.8 \mathrm{~Hz}, 1 \mathrm{H}), 3.70(\mathrm{dd}, J=13.4,6.4 \mathrm{~Hz}, 1 \mathrm{H}), 2.66-2.56(\mathrm{~m}$, $1 \mathrm{H}), 1.80$ (s, 3H), 1.07 (d, $J=6.8 \mathrm{~Hz}, 3 \mathrm{H}) \mathrm{ppm} .{ }^{13} \mathrm{C} \mathrm{NMR}$ $\left(125 \mathrm{MHz}, \mathrm{CDCl}_{3}\right) \delta=170.6$ (C), 143.3 (C), 135.9 (C), 134.6 $(\mathrm{CH}), 132.6(\mathrm{C}), 129.6(\mathrm{CH}), 128.6(\mathrm{CH}), 128.5(\mathrm{CH}), 128.2(\mathrm{CH})$, $127.7(\mathrm{CH}), 127.3(\mathrm{CH}), 54.4\left(\mathrm{CH}_{2}\right), 36.6(\mathrm{CH}), 22.8\left(\mathrm{CH}_{3}\right), 18.3$ $\left(\mathrm{CH}_{3}\right)$ ppm. IR (ATR) $v_{\max }=3028(\mathrm{w}), 2965(\mathrm{w}), 2926(\mathrm{~m}), 2871$ (w), 1655 (vs), 1594 (s), 1491 (s), 1394 (s), 1291 (s), 1276 (s), 1089 (s), 967 (m), 806 (m), 776 (m), 700 (s) cm ${ }^{-1}$. MS (ESI+) m/z $=314\left([\mathrm{M}+\mathrm{H}]^{+}\right)$. HRMS $(\mathrm{ESI}+) \mathrm{m} / \mathrm{z}$ calcd for $\mathrm{C}_{19} \mathrm{H}_{20} \mathrm{NOClNa}$ $336.1131\left([\mathrm{M}+\mathrm{Na}]^{+}\right)$, found 336.1122. 67b: $R_{\mathrm{f}}=0.10(\mathrm{PE}-$ MTBE, $2: 1) .{ }^{1} \mathrm{H}$ NMR (500 MHz, $\left.\mathrm{CDCl}_{3}\right) \delta=7.42(\mathrm{t}, J=7.6 \mathrm{~Hz}$, $2 \mathrm{H}), 7.35(\mathrm{t}, J=7.4 \mathrm{~Hz}, 1 \mathrm{H}), 7.23-7.19(\mathrm{~m}, 4 \mathrm{H}), 7.16(\mathrm{~d}, J=$ 
$7.5 \mathrm{~Hz}, 2 \mathrm{H}), 6.27(\mathrm{~d}, J=15.9 \mathrm{~Hz}, 1 \mathrm{H}), 6.13(\mathrm{dt}, J=15.8,6.8 \mathrm{~Hz}$, $1 \mathrm{H}), 3.77-3.72(\mathrm{~m}, 2 \mathrm{H}), 2.20(\mathrm{q}, J=7.0 \mathrm{~Hz}, 2 \mathrm{H}), 1.83(\mathrm{~s}, 3 \mathrm{H})$, 1.68 (pent, $J=7.5 \mathrm{~Hz}, 2 \mathrm{H}) \mathrm{ppm} .{ }^{13} \mathrm{C} \mathrm{NMR}\left(125 \mathrm{MHz}, \mathrm{CDCl}_{3}\right.$ ) $\delta=170.3$ (C), 143.0 (C), 136.0 (C), 132.3 (C), $130.4(\mathrm{CH}), 129.7$ $(\mathrm{CH}), 129.1(\mathrm{CH}), 128.5(\mathrm{CH}), 128.0(\mathrm{CH}), 127.8(\mathrm{CH}), 127.1$ (CH), $48.6\left(\mathrm{CH}_{2}\right), 30.2\left(\mathrm{CH}_{2}\right), 27.3\left(\mathrm{CH}_{2}\right), 22.7\left(\mathrm{CH}_{3}\right)$ ppm. IR (ATR) $v_{\max }=3026(\mathrm{w}), 2924(\mathrm{~m}), 2850(\mathrm{w}), 1652(\mathrm{vs}), 1595(\mathrm{~m})$, 1491 (s), 1396 (s), 1294 (m), 1089 (m), 967 (m), 775 (m), 700 (vs) $\mathrm{cm}^{-1}$. MS (ESI+) $\mathrm{m} / z=336\left([\mathrm{M}+\mathrm{Na}]^{+}\right)$. HRMS (ESI +$) \mathrm{m} / \mathrm{z}$ calcd for $\mathrm{C}_{19} \mathrm{H}_{20} \mathrm{NOClNa} 336.1131\left([\mathrm{M}+\mathrm{Na}]^{+}\right)$, found 336.1124.

(E)- $N$-(4-(4-Fluorophenyl)-2-methylbut-3-en-1-yl)- $N$-phenylacetamide (68a) and $(E)-N$-(5-(4-fluorophenyl)pent-4-en-1-yl)$\boldsymbol{N}$-phenylacetamide (68b). General procedure C was used to synthesize 68a and 68b from $N$-methylaniline $(2,214 \mathrm{mg}$, $2.0 \mathrm{mmol}$ ) and (E)-1-(para-fluorophenyl)-1,3-butadiene (51, $445 \mathrm{mg}, 3.0 \mathrm{mmol}$ ). Purification by flash column chromatography (PE-MTBE, $2: 1$ ) gave three fractions as oils. Fraction 1 contained pure compound $68 \mathrm{a}(100 \mathrm{mg}, 0.34 \mathrm{mmol}, 18 \%)$ and fraction 2 contained a mixture of $68 \mathrm{a}$ and $68 \mathrm{~b}(151 \mathrm{mg}$, $0.51 \mathrm{mmol}, 25 \%)$. Fraction 3 contained pure compound $\mathbf{6 8 b}$ (62 mg, $0.21 \mathrm{mmol}, 10 \%$ ). Prior to acetylation and chromatography, the ratio of the branched and the linear product was determined to be $50: 50$. 68a: $R_{\mathrm{f}}=0.19(\mathrm{PE}-\mathrm{MTBE}, 2: 1) .{ }^{1} \mathrm{H}$ NMR $\left(500 \mathrm{MHz}, \mathrm{CDCl}_{3}\right) \delta=7.31(\mathrm{t}, J=7.5 \mathrm{~Hz}, 2 \mathrm{H}), 7.25(\mathrm{t}, J=$ $7.4 \mathrm{~Hz}, 1 \mathrm{H}), 7.19-7.15(\mathrm{~m}, 2 \mathrm{H}), 7.08(\mathrm{~d}, J=7.4 \mathrm{~Hz}, 2 \mathrm{H}), 6.89(\mathrm{t}$, $J=8.7 \mathrm{~Hz}, 2 \mathrm{H}), 6.25$ (d, $J=15.9 \mathrm{~Hz}, 1 \mathrm{H}), 5.89$ (dd, $J=15.9,8.5$ $\mathrm{Hz}, 1 \mathrm{H}), 3.72$ (dd, $J=13.4,8.9 \mathrm{~Hz}, 1 \mathrm{H}), 3.63$ (dd, $J=13.4,6.4$ $\mathrm{Hz}, 1 \mathrm{H}), 2.57-2.49$ (m, 1H), 1.73 (s, 3H), 0.99 (d, $J=6.8 \mathrm{~Hz}, 3 \mathrm{H})$ ppm. ${ }^{13} \mathrm{C} \mathrm{NMR}\left(125 \mathrm{MHz}, \mathrm{CDCl}_{3}\right) \delta=170.6(\mathrm{C}), 161.9\left(\mathrm{~d},{ }^{1} J_{\mathrm{C}, \mathrm{F}}=\right.$ $246.0 \mathrm{~Hz}, \mathrm{C}), 143.3(\mathrm{C}), 133.6(\mathrm{CH}), 129.5(\mathrm{CH}), 128.6(\mathrm{CH})$, $128.2(\mathrm{CH}), 127.7(\mathrm{CH}), 127.5$ (d, $\left.{ }^{3} J_{\mathrm{C}, \mathrm{F}}=7.9 \mathrm{~Hz}, \mathrm{CH}\right), 115.3$ (d, $\left.{ }^{2} J_{\mathrm{C}, \mathrm{F}}=21.4 \mathrm{~Hz}, \mathrm{CH}\right), 54.4\left(\mathrm{CH}_{2}\right), 36.5(\mathrm{CH}), 22.8\left(\mathrm{CH}_{3}\right), 18.3$ $\left(\mathrm{CH}_{3}\right)$ ppm. ${ }^{19} \mathrm{~F}$ NMR $\left(500 \mathrm{MHz}, \mathrm{CDCl}_{3}\right) \delta=-115.4$ ppm. IR (ATR) $v_{\max }=3038(\mathrm{w}), 2967(\mathrm{w}), 2927(\mathrm{w}), 2871(\mathrm{w}), 1655(\mathrm{vs})$, 1594 (m), 1507 (m), 1495 (m), 1395 (m), 1293 (m), 1277 (m), 1224 (s), 1158 (m), 967 (m), 849 (m), 813 (m), $772(\mathrm{~m}), 700$ (s) $\mathrm{cm}^{-1}$. MS (ESI +$) \mathrm{m} / z=298\left([\mathrm{M}+\mathrm{H}]^{+}\right)$. HRMS (ESI +$) \mathrm{m} / z$ calcd for $\mathrm{C}_{19} \mathrm{H}_{21} \mathrm{FNO} 298.1607\left([\mathrm{M}+\mathrm{H}]^{+}\right)$, found 298.1606. 68b: $R_{\mathrm{f}}=$ 0.12 (PE-MTBE, $2: 1) .{ }^{1} \mathrm{H}$ NMR (500 $\left.\mathrm{MHz} \mathrm{CDCl}_{3}\right) \delta=7.34(\mathrm{t}$, $J=7.6 \mathrm{~Hz}, 2 \mathrm{H}), 7.27$ (t, $J=7.4 \mathrm{~Hz}, 1 \mathrm{H}), 7.19-7.14(\mathrm{~m}, 2 \mathrm{H}), 7.09$ $(\mathrm{d}, J=7.9 \mathrm{~Hz}, 2 \mathrm{H}), 6.87(\mathrm{t}, J=8.7 \mathrm{~Hz}, 2 \mathrm{H}), 6.21(\mathrm{~d}, J=15.9 \mathrm{~Hz}$, 1H), 5.99 (dt, $J=15.9,6.9 \mathrm{~Hz}, 1 \mathrm{H}), 3.69-3.64(\mathrm{~m}, 2 \mathrm{H}), 2.12$ (q, $J=7.4 \mathrm{~Hz}, 2 \mathrm{H}$ ), 1.76 (s, 3H), 1.61 (pent, $J=7.5 \mathrm{~Hz}, 2 \mathrm{H}) \mathrm{ppm}$. ${ }^{13} \mathrm{C}$ NMR $\left(125 \mathrm{MHz}, \mathrm{CDCl}_{3}\right) \delta=170.2(\mathrm{C}), 161.8\left(\mathrm{~d},{ }^{1} J_{\mathrm{C}, \mathrm{F}}=245.7\right.$ $\mathrm{Hz}, \mathrm{C}), 143.1$ (C), 133.7 (d, $\left.{ }^{4} J_{\mathrm{C}, \mathrm{F}}=3.3 \mathrm{~Hz}, \mathrm{C}\right), 129.7$ (CH), 129.4 $(\mathrm{CH}), 129.1(\mathrm{CH}), 128.1(\mathrm{CH}), 127.8(\mathrm{CH}), 127.3\left(\mathrm{~d},{ }^{3} J_{\mathrm{C}, \mathrm{F}}=7.9\right.$ $\mathrm{Hz}, \mathrm{CH}), 115.2\left(\mathrm{~d},{ }^{2} J_{\mathrm{C}, \mathrm{F}}=21.4 \mathrm{~Hz}, \mathrm{CH}\right), 48.6\left(\mathrm{CH}_{2}\right), 30.2\left(\mathrm{CH}_{2}\right)$, $27.4\left(\mathrm{CH}_{2}\right), 22.8\left(\mathrm{CH}_{3}\right)$ ppm. ${ }^{19} \mathrm{~F}$ NMR (500 MHz, $\left.\mathrm{CDCl}_{3}\right) \delta=$ -115.7 ppm. IR (ATR) $v_{\max }=3038(\mathrm{w}), 2926(\mathrm{~m}), 2853(\mathrm{w}), 1652$ (vs), 1595 (s), 1506 (s), 1495 (s), 1395 (s), 1224 (s), 967 (m), 838 (m), $770(\mathrm{~m}), 700(\mathrm{vs}) \mathrm{cm}^{-1}$. MS (ESI+) $\mathrm{m} / z=298\left([\mathrm{M}+\mathrm{H}]^{+}\right)$. HRMS (ESI +$) m / z$ calcd for $\mathrm{C}_{19} \mathrm{H}_{21} \mathrm{NOF} 298.1607\left([\mathrm{M}+\mathrm{H}]^{+}\right)$, found 298.1602.

(E)- $N$-(2-Methyldec-3-en-1-yl)- $N$-phenylacetamide (69a) and $(E)-N$-phenyl- $N$-(undec-4-en-1-yl)acetamide (69b). General procedure $\mathrm{C}$ was used to synthesize $69 \mathrm{a}$ and $69 \mathrm{~b}$ from $N$-methyl- aniline (2, $214 \mathrm{mg}, 2.0 \mathrm{mmol})$ and (E)-1,3-decadiene (52, $415 \mathrm{mg}, 3.0 \mathrm{mmol}$ ). Purification by flash column chromatography (PE-MTBE, $2: 1$ ) gave three fractions as oils. Fraction 1 contained compound 69a and a derivative with isomerized double bond (526 mg, $1.83 \mathrm{mmol}, 46 \%$ ). Fraction 2 contained compound 69a, its isomerized derivative as well as compound 69b (143 mg, $0.50 \mathrm{mmol}, 12 \%$ ). Fraction 3 contained compound 69b (112 mg, $0.39 \mathrm{mmol}, 10 \%$ ) with trace impurities of 69a. Prior to acetylation and chromatography, the ratio of the branched, the branched isomerized, and the linear product was determined to be $50: 27: 23$. 69a: ${ }^{1} \mathrm{H}$ NMR $(500 \mathrm{MHz}$, $\left.\mathrm{CDCl}_{3}\right) \delta=7.44-7.37(\mathrm{~m}, 2 \mathrm{H}), 7.35-7.29(\mathrm{~m}, 1 \mathrm{H}), 7.16(\mathrm{~d}, J=7.5$ $\mathrm{Hz}, 2 \mathrm{H}), 5.43-5.33(\mathrm{~m}, 1 \mathrm{H}), 5.26$ (dd, $J=15.4,8.0 \mathrm{~Hz}, 1 \mathrm{H}), 3.66$ (dd, $J=13.5,8.4 \mathrm{~Hz}, 1 \mathrm{H}), 3.59(\mathrm{dd}, J=13.3,6.9 \mathrm{~Hz}, 1 \mathrm{H}), 2.33$ (hept, $J=7.3 \mathrm{~Hz}, 1 \mathrm{H}), 2.95(\mathrm{q}, J=7.0 \mathrm{~Hz}, 2 \mathrm{H}), 1.81(\mathrm{~s}, 3 \mathrm{H})$, $1.35-2.26(\mathrm{~m}, 8 \mathrm{H}), 0.95(\mathrm{~d}, J=6.8 \mathrm{~Hz}, 3 \mathrm{H}), 0.87(\mathrm{t}, J=6.8 \mathrm{~Hz}$, $3 \mathrm{H}) \mathrm{ppm} .{ }^{13} \mathrm{C}$ NMR $\left(125 \mathrm{MHz}, \mathrm{CDCl}_{3}\right) \delta=170.5(\mathrm{C}), 143.4(\mathrm{C})$, $133.2(\mathrm{CH}), 130.7(\mathrm{CH}), 129.5(\mathrm{CH}), 128.2(\mathrm{CH}), 127.6(\mathrm{CH})$, $54.4\left(\mathrm{CH}_{2}\right), 35.7(\mathrm{CH}), 32.5\left(\mathrm{CH}_{2}\right), 31.7\left(\mathrm{CH}_{2}\right), 29.5\left(\mathrm{CH}_{2}\right), 28.8$ $\left(\mathrm{CH}_{2}\right), 22.9\left(\mathrm{CH}_{3}\right), 22.6\left(\mathrm{CH}_{2}\right), 14.1\left(\mathrm{CH}_{3}\right)$ ppm. IR (ATR) $v_{\max }=$ 2957 (m), 2925 (m), 2855 (m), 1661 (vs), 1595 (m), 1495 (m), 1393 (s), 1276 (m), 1217 (w), 1073 (w), 968 (m), 776 (w), 700 (vs). MS (ESI +$) \mathrm{m} / z=310\left([\mathrm{M}+\mathrm{Na}]^{+}\right)$. HRMS (ESI +$) \mathrm{m} / \mathrm{z}$ calcd for $\mathrm{C}_{19} \mathrm{H}_{29} \mathrm{NONa} 310.2147\left([\mathrm{M}+\mathrm{Na}]^{+}\right)$, found $310.2145 .69 \mathrm{~b}:{ }^{1} \mathrm{H}$ NMR (500 MHz, $\left.\mathrm{CDCl}_{3}\right) \delta=7.39(\mathrm{t}, J=7.7 \mathrm{~Hz}, 2 \mathrm{H}), 7.32(\mathrm{t}, J=$ $7.3 \mathrm{~Hz}, 1 \mathrm{H}), 7.14$ (d, $J=8.0 \mathrm{~Hz}, 2 \mathrm{H}), 5.36-5.26(\mathrm{~m}, 2 \mathrm{H})$, 3.69-3.64 (m, 2H), 1.95 (q, $J=7.0 \mathrm{~Hz}, 2 \mathrm{H}), 1.91$ (q, $J=6.2 \mathrm{~Hz}$, $2 \mathrm{H}), 1.80$ (s, 3H), 1.55 (pent, $J=7.5 \mathrm{~Hz}, 2 \mathrm{H}), 1.30-1.19(\mathrm{~m}, 8 \mathrm{H})$, $0.85(\mathrm{t}, J=6.7 \mathrm{~Hz}, 3 \mathrm{H}) \mathrm{ppm} .{ }^{13} \mathrm{C} \mathrm{NMR}\left(125 \mathrm{MHz}, \mathrm{CDCl}_{3}\right) \delta=$ 170.1 (C), 143.2 (C), $131.1(\mathrm{CH}), 129.6(\mathrm{CH}), 128.9(\mathrm{CH}), 128.1$ $(\mathrm{CH}), 127.7(\mathrm{CH}), 48.7\left(\mathrm{CH}_{2}\right), 32.5\left(\mathrm{CH}_{2}\right), 31.7\left(\mathrm{CH}_{2}\right), 29.8$ $\left(\mathrm{CH}_{2}\right), 29.4\left(\mathrm{CH}_{2}\right), 28.7\left(\mathrm{CH}_{2}\right), 27.6\left(\mathrm{CH}_{2}\right), 22.8\left(\mathrm{CH}_{3}\right), 22.6$ $\left(\mathrm{CH}_{2}\right), 14.0\left(\mathrm{CH}_{3}\right)$ ppm. IR (ATR) $v_{\max }=2955(\mathrm{w}), 2924(\mathrm{~m})$, 2854 (m), 1659 (vs), 1596 (m), 1405 (m), 1394 (s), 1294 (m), 967 (m), 774 (w), 700 (vs). MS (ESI+) $m / z=310\left([\mathrm{M}+\mathrm{Na}]^{+}\right)$. HRMS (ESI+) $\mathrm{m} / z$ calcd for $\mathrm{C}_{19} \mathrm{H}_{29} \mathrm{NONa} 310.2147\left([\mathrm{M}+\mathrm{Na}]^{+}\right)$, found 310.2143 .

$(E)-N$-(2-Methyl-6-phenylhex-3-en-1-yl)aniline $\quad(70 a)^{7 h}$ and $(E)-N$-(7-phenylhept-4-en-1-yl)aniline (70b). General procedure $\mathrm{C}$ was used without the acetylation step to synthesize 70a and 70b from $N$-methylaniline $(2,214 \mathrm{mg}, 2.0 \mathrm{mmol})$ and $(E)$-6-phenylhexa-1,3-diene $(53,475 \mathrm{mg}, 3.0 \mathrm{mmol})$. Purification by flash column chromatography (PE-MTBE, $70: 1$ ) gave three fractions as oils. Fraction 1 contained compound 70a and its double bond isomer (E)-N-(2-methyl-6-phenylhex-4-en-1-yl)aniline (301 $\mathrm{mg}, 1.13 \mathrm{mmol}, 57 \%$ ) in a ratio of $2: 1$ and fraction 2 contained a mixture of 70a and $70 b$ ( $88 \mathrm{mg}, 0.33 \mathrm{mmol}, 17 \%$ ). Fraction 3 contained pure compound $70 b$ (72 mg, $0.27 \mathrm{mmol}$, $13 \%)$. Prior to chromatography, the ratio of the branched (70a), the branched isomerized, and the linear product (70b) was determined to be $47: 28: 25$. 70a: $R_{\mathrm{f}}=0.24$ (PE-MTBE, $70: 1) .{ }^{1} \mathrm{H}$ NMR $\left(500 \mathrm{MHz}, \mathrm{CDCl}_{3}\right) \delta=7.31-7.26(\mathrm{~m}, 2 \mathrm{H})$, $7.23-7.15(\mathrm{~m}, 5 \mathrm{H}), 6.70(\mathrm{t}, J=7.3 \mathrm{~Hz}, 1 \mathrm{H}), 6.62-6.55(\mathrm{~m}, 2 \mathrm{H})$, 5.57-5.50 (m, 1H), 5.30 (dd, $J=15.4,8.0 \mathrm{~Hz}, 1 \mathrm{H}$ ), 3.66 (br. s, $1 \mathrm{H}), 3.06(\mathrm{dd}, J=11.9,5.4 \mathrm{~Hz}, 1 \mathrm{H}), 2.84(\mathrm{dd}, J=11.8,8.5 \mathrm{~Hz}$, $1 \mathrm{H}), 2.71(\mathrm{t}, J=7.5 \mathrm{~Hz}, 2 \mathrm{H}), 2.37(\mathrm{~m}, 2 \mathrm{H}), 1.05$ (d, $J=6.8 \mathrm{~Hz}$, 
3H) ppm. ${ }^{13} \mathrm{C}$ NMR (125 MHz, $\left.\mathrm{CDCl}_{3}\right) \delta=148.3$ (C), 141.8 (C), $134.3(\mathrm{CH}), 130.3(\mathrm{CH}), 129.2(\mathrm{CH}), 128.5(\mathrm{CH}), 128.3(\mathrm{CH})$, $125.8(\mathrm{CH}), 117.1(\mathrm{CH}), 112.9(\mathrm{CH}), 49.6\left(\mathrm{CH}_{2}\right), 36.7(\mathrm{CH}), 35.9$ $\left(\mathrm{CH}_{2}\right), 34.3\left(\mathrm{CH}_{2}\right), 18.1\left(\mathrm{CH}_{3}\right)$ ppm. 70b: $R_{\mathrm{f}}=0.23(\mathrm{PE}-\mathrm{MTBE}$, $70: 1) .{ }^{1} \mathrm{H}$ NMR $\left(500 \mathrm{MHz}, \mathrm{CDCl}_{3}\right) \delta=7.29(\mathrm{t}, J=7.5 \mathrm{~Hz}, 2 \mathrm{H})$, $7.23-7.16(\mathrm{~m}, 5 \mathrm{H}), 6.71(\mathrm{t}, J=7.3 \mathrm{~Hz}, 1 \mathrm{H}), 6.61(\mathrm{~d}, J=7.7 \mathrm{~Hz}$, 2H), 5.56-5.42 (m, 2H), 3.63 (br. s, $1 \mathrm{H}), 3.10$ (t, $J=7.1 \mathrm{~Hz}, 2 \mathrm{H}$ ), 2.73-2.66 (m, 2H), $2.34(\mathrm{q}, J=7.4 \mathrm{~Hz}, 2 \mathrm{H}), 2.11(\mathrm{q}, J=7.0 \mathrm{~Hz}$, 2H), 1.68 (pent, $J=7.2 \mathrm{~Hz}, 2 \mathrm{H}$ ) ppm. ${ }^{13} \mathrm{C}$ NMR $(125 \mathrm{MHz}$, $\left.\mathrm{CDCl}_{3}\right) \delta=148.4(\mathrm{C}), 142.0(\mathrm{C}), 130.2(\mathrm{CH}), 130.0(\mathrm{CH}), 129.2$ $(\mathrm{CH}), 128.4(\mathrm{CH}), 128.2(\mathrm{CH}), 125.7(\mathrm{CH}), 117.1(\mathrm{CH}), 112.7$ $(\mathrm{CH}), 43.3\left(\mathrm{CH}_{2}\right), 36.0\left(\mathrm{CH}_{2}\right), 34.4\left(\mathrm{CH}_{2}\right), 30.0\left(\mathrm{CH}_{2}\right), 29.2\left(\mathrm{CH}_{2}\right)$ ppm. IR (ATR) $v_{\max }=3412(\mathrm{w}), 3052(\mathrm{w}), 3024(\mathrm{w}), 2925(\mathrm{~m})$, 2852 (w), 1602 (vs), 1505 (vs), 1453 (m), 1319 (m), 1257 (m), 1179 (w), 968 (m), 867 (w), 745 (s), 691 (s) cm cm $^{-1}$ MS (ESI+) m/z $=266\left([\mathrm{M}+\mathrm{H}]^{+}\right)$. HRMS $(\mathrm{ESI}+) \mathrm{m} / z$ calcd for $\mathrm{C}_{19} \mathrm{H}_{24} \mathrm{~N} 266.1909$ $\left([\mathrm{M}+\mathrm{H}]^{+}\right)$, found 266.1901.

(E)-N-(2,3-Dimethyl-4-phenylbut-3-en-1-yl)- $N$-phenylacetamide (71a) and $(E)-N$-(4-methyl-5-phenylpent-4-en-1-yl)- $N$-phenylacetamide (71b). General procedure $C$ was used to synthesize 71a and $71 \mathrm{~b}$ from $N$-methylaniline $(2,214 \mathrm{mg}, 2.0 \mathrm{mmol})$ and $(E)$ 2-methyl-1-phenyl-1,3-butadiene (54, $433 \mathrm{mg}, 3.0 \mathrm{mmol})$. Purification by flash column chromatography (PE-MTBE, 2:1) gave three fractions as oils. Fraction 1 contained pure compound 71a (159 mg, $0.54 \mathrm{mmol}, 27 \%)$ and fraction 2 contained a mixture of 71a and $71 \mathrm{~b}$ (236 mg, $0.81 \mathrm{mmol}, 41 \%)$. Fraction 3 contained pure compound $71 \mathrm{~b}$ (30 mg, $0.10 \mathrm{mmol}, 5 \%)$. Prior to acetylation and chromatography, the ratio of the branched and the linear product was determined to be $51: 49$. 71a: $R_{\mathrm{f}}=0.26(\mathrm{PE}-\mathrm{MTBE}, 2: 1) .{ }^{1} \mathrm{H}$ NMR $\left(500 \mathrm{MHz}, \mathrm{CDCl}_{3}\right) \delta=$ 7.40-7.36 (m, 2H), 7.33-7.28 (m, 3H), 7.23-7.16 (m, 5H), 6.30 (s, 1H), $3.87(\mathrm{dd}, J=13.6,9.1 \mathrm{~Hz}, 1 \mathrm{H}), 3.79(\mathrm{dd}, J=13.6,6.1$ $\mathrm{Hz}, 1 \mathrm{H}), 2.66-2.57$ (m, 1H), 1.83 (s, 3H), 1.68 (s, 3H), 1.08 (d, $J=7.0 \mathrm{~Hz}, 3 \mathrm{H}) \mathrm{ppm} .{ }^{13} \mathrm{C} \mathrm{NMR}\left(125 \mathrm{MHz}, \mathrm{CDCl}_{3}\right) \delta=170.3(\mathrm{C})$, 143.1 (C), 140.4 (C), 138.0 (C), $129.3(\mathrm{CH}), 128.7(\mathrm{CH}), 128.1$ $(\mathrm{CH}), 127.9(\mathrm{CH}), 127.5(\mathrm{CH}), 126.0(\mathrm{CH}), 125.9(\mathrm{CH}), 52.7$ $\left(\mathrm{CH}_{2}\right), 42.1(\mathrm{CH}), 22.7\left(\mathrm{CH}_{3}\right), 17.1\left(\mathrm{CH}_{3}\right), 13.7\left(\mathrm{CH}_{3}\right)$ ppm. IR (ATR) $v_{\max }=3057(\mathrm{w}), 3025(\mathrm{w}), 2967(\mathrm{w}), 2933(\mathrm{w}), 2874(\mathrm{w})$, 1658 (vs), 1596 (m), 1496 (s), 1395 (s), 1295 (m), 1277 (m), 779 (m), $745(\mathrm{~m}), 700(\mathrm{vs}) \mathrm{cm}^{-1}$. MS (ESI+) $\mathrm{m} / z=316\left([\mathrm{M}+\mathrm{Na}]^{+}\right)$. HRMS (ESI +$) m / z$ calcd for $\mathrm{C}_{20} \mathrm{H}_{23} \mathrm{NONa} 316.1677\left([\mathrm{M}+\mathrm{Na}]^{+}\right)$, found 316.1682. 71b: $R_{\mathrm{f}}=0.17$ (PE-MTBE, 2:1). ${ }^{1} \mathrm{H}$ NMR $\left(500 \mathrm{MHz}, \mathrm{CDCl}_{3}\right) \delta=7.43(\mathrm{t}, J=7.6 \mathrm{~Hz}, 2 \mathrm{H}), 7.36(\mathrm{t}, J=7.4 \mathrm{~Hz}$, $1 \mathrm{H}), 7.29(\mathrm{t}, J=7.6 \mathrm{~Hz}, 2 \mathrm{H}), 7.21-7.15(\mathrm{~m}, 5 \mathrm{H}), 6.21(\mathrm{~s}, 1 \mathrm{H})$, $3.77-3.71(\mathrm{~m}, 2 \mathrm{H}), 2.20-2.14(\mathrm{~m}, 2 \mathrm{H}), 1.85(\mathrm{~s}, 3 \mathrm{H}), 1.80(\mathrm{~d}, J=$ $1.3 \mathrm{~Hz}, 3 \mathrm{H}), 1.79-1.73(\mathrm{~m}, 2 \mathrm{H}) \mathrm{ppm} .{ }^{13} \mathrm{C}$ NMR $(125 \mathrm{MHz}$, $\left.\mathrm{CDCl}_{3}\right) \delta=170.2(\mathrm{C}), 143.2(\mathrm{C}), 138.4(\mathrm{C}), 138.1(\mathrm{C}), 129.7(\mathrm{CH})$, $128.8(\mathrm{CH}), 128.1(\mathrm{CH}), 128.0(\mathrm{CH}), 127.8(\mathrm{CH}), 125.8(\mathrm{CH})$, $125.2(\mathrm{CH}), 48.9\left(\mathrm{CH}_{2}\right), 37.8\left(\mathrm{CH}_{2}\right), 26.1\left(\mathrm{CH}_{2}\right), 22.8\left(\mathrm{CH}_{3}\right), 17.6$ $\left(\mathrm{CH}_{3}\right)$ ppm. IR (ATR) $v_{\max }=3057(\mathrm{w}), 3025(\mathrm{w}), 2932(\mathrm{w}), 2859$ (w), 1656 (s), 1597 (s), 1496 (s), 1397 (s), 1298 (m), 1076 (w), 743 (m), 700 (vs) $\mathrm{cm}^{-1}$. MS (ESI+) $m / z=316\left([\mathrm{M}+\mathrm{Na}]^{+}\right)$. HRMS (ESI+) $\mathrm{m} / z$ calcd for $\mathrm{C}_{20} \mathrm{H}_{23} \mathrm{NONa} 316.1677\left([\mathrm{M}+\mathrm{Na}]^{+}\right)$, found 316.1682 .

$\boldsymbol{N}$-Phenyl- $\boldsymbol{N}$-(2-methyldecyl)acetamide (72). Under an inert atmosphere of argon, a flask was charged with a mixture of 69a and the derivative with isomerized double bond (350 mg, $1.22 \mathrm{mmol}), \mathrm{Pd} / \mathrm{C}$ (17 mg, $5 \mathrm{wt} \%$ ) and dry methanol $(20 \mathrm{~mL})$. Then the argon atmosphere was purged with hydrogen gas and the reaction mixture was stirred for $2 \mathrm{~h}$ at room temperature. After the starting materials had been completely consumed (monitored by TLC), the solvent was removed under reduced pressure in the presence of Celite ${ }^{\circledR}$. After purification by flash column chromatography $\left(\mathrm{SiO}_{2}, \mathrm{PE}-\mathrm{MTBE}, 5: 1\right)$, compound 72 (301 $\mathrm{mg}, 1.04 \mathrm{mmol}, 85 \%$ ) was isolated as a colorless oil. 72: ${ }^{1} \mathrm{H}$ NMR $\left(500 \mathrm{MHz}, \mathrm{CDCl}_{3}\right) \delta=7.41(\mathrm{t}, J=7.7 \mathrm{~Hz}, 2 \mathrm{H})$, $7.33(\mathrm{t}, J=7.3 \mathrm{~Hz}, 1 \mathrm{H}), 7.16(\mathrm{~d}, J=7.5 \mathrm{~Hz}, 2 \mathrm{H}), 3.65(\mathrm{dd}, J=$ 13.2, 8.2 Hz, 1H), $3.54(\mathrm{dd}, J=13.4,6.7 \mathrm{~Hz}, 1 \mathrm{H}), 1.83(\mathrm{~s}, 3 \mathrm{H})$, 1.60-1.51 (m, 1H), 1.32-1.11 (m, $14 \mathrm{H}), 0.89-0.84(\mathrm{~m}, 6 \mathrm{H})$ ppm. ${ }^{13} \mathrm{C}$ NMR (125 MHz, $\mathrm{CDCl}_{3}$ ) $\delta=170.6$ (C), 143.4 (C), 129.6 $(\mathrm{CH}), 128.0(\mathrm{CH}), 127.6(\mathrm{CH}), 54.7\left(\mathrm{CH}_{2}\right), 34.2\left(\mathrm{CH}_{2}\right), 31.9$ $\left(\mathrm{CH}_{2}\right), 31.5(\mathrm{CH}), 29.8\left(\mathrm{CH}_{2}\right), 29.5\left(\mathrm{CH}_{2}\right), 29.3\left(\mathrm{CH}_{2}\right), 26.8$ $\left(\mathrm{CH}_{2}\right), 22.9\left(\mathrm{CH}_{3}\right), 22.6\left(\mathrm{CH}_{2}\right), 17.3\left(\mathrm{CH}_{3}\right), 14.1\left(\mathrm{CH}_{3}\right)$ ppm. IR (ATR) $v_{\max }=2956(\mathrm{~m}), 2924(\mathrm{~s}), 2854(\mathrm{~m}), 1662(\mathrm{vs}), 1595(\mathrm{~m})$, 1495 (m), 1455 (m), 1395 (s), 1290 (m), 1276 (m), 776 (w), 700 (s) $\mathrm{cm}^{-1}$. MS (ESI+) $\mathrm{m} / z=312\left([\mathrm{M}+\mathrm{Na}]^{+}\right)$. HRMS (ESI+) $\mathrm{m} / \mathrm{z}$ calcd for $\mathrm{C}_{19} \mathrm{H}_{31} \mathrm{NONa} 312.2303\left([\mathrm{M}+\mathrm{Na}]^{+}\right)$, found 312.2294.

para-Toluenesulfonamide $\mathbf{7 6 b}$. General procedure $\mathrm{D}$ was used to synthesize $\mathbf{7 6 b}$ from $N$-methylbenzylamine (38, $242 \mathrm{mg}, \quad 2.0 \mathrm{mmol}$ ) and (E)-1-phenyl-1,3-butadiene (49, $391 \mathrm{mg}, 3.0 \mathrm{mmol}$ ). Purification by flash column chromatography (PE-MTBE, $12: 1$ ) gave one fraction (504 mg) as an oil of high viscosity. According to ${ }^{1} \mathrm{H}$ NMR spectroscopy, the fraction contained a mixture of 76b (466 mg, $1.15 \mathrm{mmol}, 58 \%$ ) and tosylated $\mathrm{N}$-methylbenzylamine (35 mg, $0.13 \mathrm{mmol}$ ). Prior to tosylation and chromatography, the ratio of the branched and the linear product was determined to be $7: 93.76 \mathbf{b}: R_{\mathrm{f}}=$ 0.25 (PE-MTBE, $12: 1) .{ }^{1} \mathrm{H}$ NMR (300 MHz, $\left.\mathrm{CDCl}_{3}\right) \delta=7.62$ (d, $J=8.3 \mathrm{~Hz}, 2 \mathrm{H}), 7.31-7.16(\mathrm{~m}, 12 \mathrm{H}), 6.27$ (d, $J=15.8 \mathrm{~Hz}, 1 \mathrm{H})$, $6.13(\mathrm{dt}, J=15.8,6.4 \mathrm{~Hz}, 1 \mathrm{H}), 5.11(\mathrm{t}, J=7.3 \mathrm{~Hz}, 1 \mathrm{H}), 2.62$ (s, $3 \mathrm{H}), 2.37$ (s, 3H), 2.18-1.99 (m, 3H), 1.88-1.75 (m, 1H) ppm. ${ }^{13} \mathrm{C}$ NMR (75 MHz, $\mathrm{CDCl}_{3}$ ) $\delta=143.0$ (C), 138.0 (C), 137.5 (C), $137.2(\mathrm{C}), 130.7(\mathrm{CH}), 129.5(\mathrm{CH}), 129.1(\mathrm{CH}), 128.5(\mathrm{CH}), 128.4$ $(\mathrm{CH}), 128.0(\mathrm{CH}), 127.8(\mathrm{CH}), 127.2(\mathrm{CH}), 127.0(\mathrm{CH}), 125.9$ $(\mathrm{CH}), 59.5(\mathrm{CH}), 30.3\left(\mathrm{CH}_{2}\right), 29.9\left(\mathrm{CH}_{2}\right), 28.8\left(\mathrm{CH}_{3}\right), 21.5\left(\mathrm{CH}_{3}\right)$ ppm. IR (ATR) $v_{\max }=3062(\mathrm{w}), 3028(\mathrm{w}), 2941(\mathrm{w}), 2872(\mathrm{w})$, 1598 (m), 1494 (m), 1452 (m), 1333 (s), 1131 (vs), 1088 (s), 933 (s), $813(\mathrm{~m}), 736(\mathrm{~s}), 712(\mathrm{vs}) \mathrm{cm}^{-1}$. MS (ESI+) $\mathrm{m} / z=428$ $\left([\mathrm{M}+\mathrm{Na}]^{+}\right)$. HRMS (ESI +$) \mathrm{m} / z$ calcd for $\mathrm{C}_{25} \mathrm{H}_{27} \mathrm{NO}_{2} \mathrm{SNa}$ $428.1660\left([\mathrm{M}+\mathrm{Na}]^{+}\right)$, found 428.1666 .

para-Toluenesulfonamide $\mathbf{7 7 b}$. General procedure D was used to synthesize $\mathbf{7 7 b}$ from $N$-methylbenzylamine (38, $242 \mathrm{mg}, 2.0 \mathrm{mmol}$ ) and (E)-1-(para-chlorophenyl)-1,3-butadiene $(50,494 \mathrm{mg}, 3.0 \mathrm{mmol})$. Purification by flash column chromatography (PE-MTBE, $12: 1$ ) gave one fraction (615 mg) as an oil of high viscosity. According to ${ }^{1} \mathrm{H}$ NMR spectroscopy, the fraction contained a mixture of $77 \mathbf{b}(590 \mathrm{mg}, 1.34 \mathrm{mmol}$, $67 \%$ ) and tosylated $N$-methylbenzylamine (25 $\mathrm{mg}, 0.09 \mathrm{mmol}$ ). Prior to tosylation and chromatography, the ratio of the branched and the linear product was determined to be $8: 92$. 77b: $R_{\mathrm{f}}=0.22(\mathrm{PE}-\mathrm{MTBE}, 12: 1) .{ }^{1} \mathrm{H}$ NMR (500 MHz, $\left.\mathrm{CDCl}_{3}\right) \delta$ $=7.62(\mathrm{~d}, J=8.4 \mathrm{~Hz}, 2 \mathrm{H}), 7.30-7.17(\mathrm{~m}, 11 \mathrm{H}), 6.28(\mathrm{~d}, J=15.8$ 
$\mathrm{Hz}, 1 \mathrm{H}), 6.14(\mathrm{dt}, J=15.8,6.7 \mathrm{~Hz}, 1 \mathrm{H}), 5.13(\mathrm{t}, J=7.6 \mathrm{~Hz}, 1 \mathrm{H})$, $2.63(\mathrm{~s}, 3 \mathrm{H}), 2.38(\mathrm{~s}, 3 \mathrm{H}), 2.22-2.03(\mathrm{~m}, 3 \mathrm{H}), 1.90-1.82(\mathrm{~m}, 1 \mathrm{H})$ ppm. ${ }^{13} \mathrm{C}$ NMR (125 MHz, $\left.\mathrm{CDCl}_{3}\right) \delta=143.0$ (C), 138.0 (C), 137.2 (C), 136.0 (C), 132.5 (C), $129.9(\mathrm{CH}), 129.5(\mathrm{CH}), 129.4(\mathrm{CH})$, $128.6(\mathrm{CH}), 128.4(\mathrm{CH}), 128.0(\mathrm{CH}), 127.8(\mathrm{CH}), 127.1(\mathrm{CH})$, $59.4(\mathrm{CH}), 30.2\left(\mathrm{CH}_{2}\right), 29.8\left(\mathrm{CH}_{2}\right), 28.7\left(\mathrm{CH}_{3}\right), 21.4\left(\mathrm{CH}_{3}\right) \mathrm{ppm}$. IR (ATR) $v_{\max }=3064(\mathrm{w}), 3032(\mathrm{w}), 2939(\mathrm{w}), 1599(\mathrm{~m}), 1493$ (m), 1455 (m), 1335 (s), 1157 (vs), 1090 (s), 935 (s), 812 (s), 701 (s), 659 (vs) $\mathrm{cm}^{-1}$. MS (ESI+) $\mathrm{m} / z=462\left([\mathrm{M}+\mathrm{Na}]^{+}\right)$. HRMS $(\mathrm{ESI}+) \mathrm{m} / z$ calcd for $\mathrm{C}_{25} \mathrm{H}_{26} \mathrm{NO}_{2} \mathrm{SClNa} 462.1270\left([\mathrm{M}+\mathrm{Na}]^{+}\right)$, found 462.1267 .

para-Toluenesulfonamide $\mathbf{7 8 b}$. General procedure $\mathrm{D}$ was used to synthesize $\mathbf{7 8 b}$ from $N$-methylbenzylamine (38, $242 \mathrm{mg}, 2.0 \mathrm{mmol}$ ) and (E)-1-(para-fluorophenyl)-1,3-butadiene (51, $445 \mathrm{mg}, 3.0 \mathrm{mmol})$. Purification by flash column chromatography (PE-MTBE, $12: 1$ ) gave one fraction (661 mg) as an oil of high viscosity. According to ${ }^{1} \mathrm{H}$ NMR spectroscopy, the fraction contained a mixture of $78 \mathrm{~b}(597 \mathrm{mg}, 1.41 \mathrm{mmol}, 71 \%)$ and tosylated $N$-methylbenzylamine ( $64 \mathrm{mg}, 0.23 \mathrm{mmol}$ ). Prior to tosylation and chromatography, the ratio of the branched and the linear product was determined to be $9: 91.78 \mathrm{~b}: R_{\mathrm{f}}=$ 0.24 (PE-MTBE, $12: 1$ ). ${ }^{1} \mathrm{H}$ NMR $\left(500 \mathrm{MHz}, \mathrm{CDCl}_{3}\right) \delta=7.64$ (d, $J=8.3 \mathrm{~Hz}, 2 \mathrm{H}), 7.33-7.25$ (m, 6H), 7.24-7.19 (m, 3H), 6.99 (br. $\mathrm{t}, J=8.7 \mathrm{~Hz}, 2 \mathrm{H}), 6.30(\mathrm{~d}, J=15.9 \mathrm{~Hz}, 1 \mathrm{H}), 6.08(\mathrm{dt}, J=15.9,6.8$ $\mathrm{Hz}, 1 \mathrm{H}), 5.15(\mathrm{t}, J=7.6 \mathrm{~Hz}, 1 \mathrm{H}), 2.65(\mathrm{~s}, 3 \mathrm{H}), 2.40(\mathrm{~s}, 3 \mathrm{H})$, 2.23-2.14 (m, 2H), 2.12-2.04 (m, 1H), 1.90-1.83 (m, 1H) ppm. ${ }^{13} \mathrm{C}$ NMR $\left(125 \mathrm{MHz}, \mathrm{CDCl}_{3}\right) \delta=161.9\left(\mathrm{~d},{ }^{1} J_{\mathrm{C}, \mathrm{F}}=245.9 \mathrm{~Hz}, \mathrm{CF}\right)$, 143.0 (C), 138.0 (C), 137.2 (C), 133.6 (d, $\left.{ }^{4} J_{\mathrm{C}, \mathrm{F}}=3.2 \mathrm{~Hz}, \mathrm{C}\right), 129.4$ $(\mathrm{CH}), 128.4(\mathrm{CH}), 128.0(\mathrm{CH}), 127.3\left(\mathrm{~d},{ }^{3} J_{\mathrm{C}, \mathrm{F}}=7.8 \mathrm{~Hz}, \mathrm{CH}\right)$, $127.1(\mathrm{CH}), 115.3\left(\mathrm{~d},{ }^{2} J_{\mathrm{C}, \mathrm{F}}=21.5 \mathrm{~Hz}, \mathrm{CH}\right), 59.4(\mathrm{CH}), 30.3$ $\left(\mathrm{CH}_{2}\right), 29.8\left(\mathrm{CH}_{2}\right), 28.7\left(\mathrm{CH}_{3}\right), 21.4\left(\mathrm{CH}_{3}\right)$ ppm. ${ }^{19} \mathrm{~F}$ NMR $\left(500 \mathrm{MHz}, \mathrm{CDCl}_{3}\right) \delta=-115.5 \mathrm{ppm}$. IR (ATR) $v_{\max }=3059(\mathrm{w})$, 3031 (w), 2948 (w), 2920 (w), 1598 (m), 1508 (m), 1452 (m), $1336(\mathrm{~s}), 1228(\mathrm{~m}), 1154(\mathrm{~s}), 1088(\mathrm{~m}), 972(\mathrm{~m}), 927$ (s), $820(\mathrm{~m})$, 699 (s), $656(\mathrm{~s}) \mathrm{cm}^{-1}$. MS (ESI+) $\mathrm{m} / z=446\left([\mathrm{M}+\mathrm{Na}]^{+}\right)$. HRMS (ESI+) $m / z$ calcd for $\mathrm{C}_{25} \mathrm{H}_{26} \mathrm{NO}_{2} \mathrm{SFNa} 446.1566\left([\mathrm{M}+\mathrm{Na}]^{+}\right)$, found 446.1560 .

para-Toluenesulfonamide $79 \mathrm{~b}$. General procedure $\mathrm{D}$ was used to synthesize 79b from $N$-methylbenzylamine (38, $242 \mathrm{mg}, 2.0 \mathrm{mmol}$ ) and (E)-1-(para-methoxyphenyl)-1,3-butadiene $(73,481 \mathrm{mg}, 3.0 \mathrm{mmol})$. Purification by flash column chromatography (PE-MTBE, $6: 1$ ) gave one fraction as an oil of high viscosity. According to ${ }^{1} \mathrm{H}$ NMR spectroscopy, the fraction contained 79b (524 mg, $1.20 \mathrm{mmol}, 60 \%$ ) and trace amounts of the corresponding branched product. Prior to tosylation and chromatography, the ratio of the branched and the linear product was determined to be $10: 90$. 79b: $R_{\mathrm{f}}=0.30(\mathrm{PE}-$ MTBE, $6: 1) .{ }^{1} \mathrm{H}$ NMR $\left(500 \mathrm{MHz}, \mathrm{CDCl}_{3}\right) \delta=7.65(\mathrm{~d}, J=8.3 \mathrm{~Hz}$, $2 \mathrm{H}), 7.29-7.24(\mathrm{~m}, 5 \mathrm{H}), 7.24-7.21(\mathrm{~m}, 4 \mathrm{H}), 6.85(\mathrm{~d}, J=8.7 \mathrm{~Hz}$, $2 \mathrm{H}), 6.27$ (d, $J=15.9 \mathrm{~Hz}, 1 \mathrm{H}), 6.02(\mathrm{dt}, J=15.8,6.6 \mathrm{~Hz}, 1 \mathrm{H})$, $5.14(\mathrm{t}, J=7.4 \mathrm{~Hz}, 1 \mathrm{H}), 3.81(\mathrm{~s}, 3 \mathrm{H}), 2.65(\mathrm{~s}, 3 \mathrm{H}), 2.40(\mathrm{~s}, 3 \mathrm{H})$, 2.22-2.04 (m, 3H), 1.87-1.79 (m, 1H) ppm. ${ }^{13} \mathrm{C}$ NMR (125 MHz, $\left.\mathrm{CDCl}_{3}\right) \delta=158.8(\mathrm{C}), 143.0(\mathrm{C}), 138.1$ (C), 137.3 (C), 130.3 (C), $130.1(\mathrm{CH}), 129.4(\mathrm{CH}), 128.4(\mathrm{CH}), 128.0(\mathrm{CH}), 127.7(\mathrm{CH})$, $127.2(\mathrm{CH}), 127.0(\mathrm{CH}), 126.9(\mathrm{CH}), 59.5(\mathrm{CH}), 55.3\left(\mathrm{CH}_{3}\right), 30.4$ $\left(\mathrm{CH}_{2}\right), 29.9\left(\mathrm{CH}_{2}\right), 28.8\left(\mathrm{CH}_{3}\right), 21.5\left(\mathrm{CH}_{3}\right)$ ppm. IR (ATR) $v_{\max }=$
3062 (w), 3032 (w), 2956 (w), 2923 (m), 2853 (m), 1608 (m), 1512 (s), 1457 (m), 1335 (m), 1248 (s), 1156 (vs), 1089 (m), 1033 (m), $934(\mathrm{~m}), 809$ (s), 701 (s), 660 (vs) cm ${ }^{-1}$. MS (ESI+) m/z= $458\left([\mathrm{M}+\mathrm{Na}]^{+}\right)$. HRMS (ESI +$) m / z$ calcd for $\mathrm{C}_{26} \mathrm{H}_{29} \mathrm{NO}_{3} \mathrm{SNa}$ 458.1766 $\left([\mathrm{M}+\mathrm{Na}]^{+}\right)$, found 458.1758 .

para-Toluenesulfonamide $\mathbf{8 0 b}$. General procedure D was used to synthesize $\mathbf{8 0 b}$ from $N$-methylbenzylamine (38, $242 \mathrm{mg}, 2.0 \mathrm{mmol}$ ) and (E)-1-(ortho-methylphenyl)-1,3-butadiene (74, $433 \mathrm{mg}, 3.0 \mathrm{mmol}$ ). Purification by flash column chromatography (PE-MTBE, 9:1) gave one fraction (605 mg) as an oil of high viscosity. According to ${ }^{1} \mathrm{H}$ NMR spectroscopy, the fraction contained a mixture of $80 b$ (575 mg, $1.37 \mathrm{mmol}$, $69 \%$ ), tosylated $N$-methylbenzylamine (30 $\mathrm{mg}, 0.11 \mathrm{mmol}$ ), and trace amounts of the corresponding branched product. Prior to tosylation and chromatography, the ratio of the branched and the linear product was determined to be $13: 87$. 80b: $R_{\mathrm{f}}=0.18(\mathrm{PE}-\mathrm{MTBE}, 9: 1) .{ }^{1} \mathrm{H}$ NMR $\left(500 \mathrm{MHz}, \mathrm{CDCl}_{3}\right) \delta=$ $7.65(\mathrm{~d}, J=8.3 \mathrm{~Hz}, 2 \mathrm{H}), 7.39(\mathrm{~d}, J=6.6 \mathrm{~Hz}, 1 \mathrm{H}), 7.30-7.26(\mathrm{~m}$ $3 \mathrm{H}), 7.25-7.20(\mathrm{~m}, 4 \mathrm{H}), 7.19-7.12(\mathrm{~m}, 3 \mathrm{H}), 6.53(\mathrm{~d}, J=15.9 \mathrm{~Hz}$, $1 \mathrm{H}), 6.01(\mathrm{dt}, J=15.8,6.8 \mathrm{~Hz}, 1 \mathrm{H}), 5.16(\mathrm{t}, J=7.5 \mathrm{~Hz}, 1 \mathrm{H}), 2.67$ $(\mathrm{s}, 3 \mathrm{H}), 2.40(\mathrm{~s}, 3 \mathrm{H}), 2.32(\mathrm{~s}, 2 \mathrm{H}), 2.29-2.08(\mathrm{~m}, 3 \mathrm{H}), 1.90-1.80$ (m, 1H) ppm. $\left.{ }^{13} \mathrm{C} \mathrm{NMR} \mathrm{(125} \mathrm{MHz,} \mathrm{CDCl}_{3}\right) \delta=143.0$ (C), 138.0 (C), 137.3 (C), $136.6(\mathrm{C}), 135.0(\mathrm{C}), 130.5(\mathrm{CH}), 130.1(\mathrm{CH})$, $129.4(\mathrm{CH}), 128.7(\mathrm{CH}), 128.4(\mathrm{CH}), 128.1(\mathrm{CH}), 127.8(\mathrm{CH})$, $127.2(\mathrm{CH}), 127.0(\mathrm{CH}), 126.0(\mathrm{CH}), 125.4(\mathrm{CH}), 59.4(\mathrm{CH}), 30.3$ $\left(\mathrm{CH}_{2}\right), 30.2\left(\mathrm{CH}_{2}\right), 28.8\left(\mathrm{CH}_{3}\right), 21.5\left(\mathrm{CH}_{3}\right), 19.8\left(\mathrm{CH}_{3}\right)$ ppm. IR $\left(\right.$ ATR ) $v_{\max }=3064(\mathrm{w}), 3031(\mathrm{w}), 2928(\mathrm{w}), 2868(\mathrm{w}), 1600(\mathrm{w})$, 1496 (w), 1456 (m), 1336 (s), 1157 (vs), 1090 (m), 936 (s), 815 (m), 736 (s), 701 (vs), 660 (vs) $\mathrm{cm}^{-1}$. MS (ESI+) $\mathrm{m} / \mathrm{z}=442$ $\left([\mathrm{M}+\mathrm{Na}]^{+}\right)$. HRMS (ESI +$) \mathrm{m} / z$ calcd for $\mathrm{C}_{26} \mathrm{H}_{29} \mathrm{NO}_{2} \mathrm{SNa}$ $442.1817\left([\mathrm{M}+\mathrm{Na}]^{+}\right)$, found 442.1814 .

para-Toluenesulfonamide $\mathbf{8 1 b}$. General procedure D was used to synthesize $\mathbf{8 1 b}$ from $N$-methylbenzylamine (38, $242 \mathrm{mg}, 2.0 \mathrm{mmol}$ ) and (E)-1-(ortho-methoxyphenyl)-1,3-butadiene $(75,481 \mathrm{mg}, 3,0 \mathrm{mmol})$. Purification by flash column chromatography (PE-MTBE, 1:1) gave one fraction as an oil of high viscosity. According to ${ }^{1} \mathrm{H}$ NMR spectroscopy, the fraction contained $\mathbf{8 1 \mathrm { b }}$ (574 $\mathrm{mg}, 1.32 \mathrm{mmol}, 66 \%$ ) and trace amounts of the corresponding branched product. Prior to tosylation and chromatography, the ratio of the branched and the linear product was determined to be $11: 89$. 81b: $R_{\mathrm{f}}=0.44(\mathrm{PE}-$ MTBE, 9:1) ${ }^{1} \mathrm{H}$ NMR $\left(500 \mathrm{MHz}, \mathrm{CDCl}_{3}\right) \delta=7.63(\mathrm{~d}, J=8.3 \mathrm{~Hz}$, $2 \mathrm{H}), 7.36(\mathrm{dd}, J=7.6,1.4 \mathrm{~Hz}, 1 \mathrm{H}), 7.28-7.15(\mathrm{~m}, 8 \mathrm{H}), 6.89(\mathrm{t}$, $J=7.3 \mathrm{~Hz}, 1 \mathrm{H}), 6.84(\mathrm{~d}, J=8.2,1 \mathrm{H}), 6.62(\mathrm{~d}, J=16.0 \mathrm{~Hz}, 1 \mathrm{H})$, $6.13(\mathrm{dt}, J=15.9,6.7 \mathrm{~Hz}, 1 \mathrm{H}), 5.13(\mathrm{t}, J=7.4 \mathrm{~Hz}, 1 \mathrm{H}), 3.82(\mathrm{~s}$, $3 \mathrm{H}), 2.63(\mathrm{~s}, 3 \mathrm{H}), 2.37(\mathrm{~s}, 3 \mathrm{H}), 2.20-2.03(\mathrm{~m}, 3 \mathrm{H}), 1.85-1.76(\mathrm{~m}$, 1H) ppm. ${ }^{13} \mathrm{C}$ NMR (125 MHz, $\left.\mathrm{CDCl}_{3}\right) \delta=156.3$ (C), 142.9 (C), 138.2 (C), 137.3 (C), $129.9(\mathrm{CH}), 129.5(\mathrm{CH}), 128.4(\mathrm{CH}), 128.1$ $(\mathrm{CH}), 127.7(\mathrm{CH}), 127.2(\mathrm{CH}), 126.5(\mathrm{C}), 126.5(\mathrm{CH}), 125.4(\mathrm{CH})$, $120.6(\mathrm{CH}), 110.8(\mathrm{CH}), 59.6(\mathrm{CH}), 55.4\left(\mathrm{CH}_{3}\right), 30.4\left(\mathrm{CH}_{2}\right), 28.8$ $\left(\mathrm{CH}_{3}\right), 21.5\left(\mathrm{CH}_{3}\right)$ ppm. IR (ATR) $v_{\max }=3063(\mathrm{w}), 3031(\mathrm{w})$, 2924 (w), 2851 (w), 1597 (m), 1489 (m), 1455 (m), 1333 (s), 1242 (s), 1155 (vs), 1088 (m), 1027 (m), 933 (s), 813 (m), 751 (s), 700 (vs), 658 (vs) $\mathrm{cm}^{-1}$. MS (ESI+) $m / z=458\left([\mathrm{M}+\mathrm{Na}]^{+}\right)$. HRMS $(\mathrm{ESI}+) \mathrm{m} / z$ calcd for $\mathrm{C}_{26} \mathrm{H}_{29} \mathrm{NO}_{3} \mathrm{SNa} 458.1766\left([\mathrm{M}+\mathrm{Na}]^{+}\right)$, found 458.1778 . 


\section{Acknowledgements}

We thank the Deutsche Forschungsgemeinschaft for financial support of our research as well as Jessica Reimer and Leoni Fritsche for experimental assistance.

\section{Notes and references}

1 For reviews on the hydroaminoalkylation of alkenes, see: (a) P. W. Roesky, Angew. Chem., Int. Ed., 2009, 48, 4892; (b) T.-Q. He, X.-J. Zheng, H. Cai and Z.-L. Xue, Chin. J. Inorg. Chem., 2014, 30, 53; (c) E. Chong, P. Garcia and L. L. Schafer, Synthesis, 2014, 46, 2884.

2 R. N. Salvatore, C. H. Yon and K. W. Jung, Tetrahedron, 2001, 57, 7785.

3 Ruthenium catalysts: (a) C.-H. Jun, D.-C. Hwang and S.-J. Na, Chem. Commun., 1998, 1405; (b) N. Chatani, T. Asaumi, S. Yorimitsu, T. Ikeda, F. Kakiuci and S. Murai, J. Am. Chem. Soc., 2001, 123, 10935.

4 Iridium catalysts: S. Pan, K. Endo and T. Shibata, Org. Lett., 2011, 13, 4692.

5 Group 5 metal catalysts: (a) M. G. Clerici and F. Maspero, Synthesis, 1980, 305; (b) W. A. Nugent, D. W. Ovenall and S. J. Holmes, Organometallics, 1983, 2, 161; (c) S. B. Herzon and J. F. Hartwig, J. Am. Chem. Soc., 2007, 129, 6690; (d) S. B. Herzon and J. F. Hartwig, J. Am. Chem. Soc., 2008, 130, 14940; (e) P. Eisenberger, R. O. Ayinla, J. M. P. Lauzon and L. L. Schafer, Angew. Chem., Int. Ed., 2009, 48, 8361; (f) P. Eisenberger and L. L. Schafer, Pure Appl. Chem., 2010, 82, 1503; (g) G. Zi, F. Zhang and H. Song, Chem. Commun., 2010, 46, 6296; $(h)$ A. L. Reznichenko, T. J. Emge, S. Audörsch, E. G. Klauber, K. C. Hultzsch and B. Schmidt, Organometallics, 2011, 30, 921; (i) A. L. Reznichenko and K. C. Hultzsch, J. Am. Chem. Soc., 2012, 134, 3300; (j) P. Garcia, Y. Y. Lau, M. R. Perry and L. L. Schafer, Angew. Chem., Int. Ed., 2013, 52, 9144; (k) Z. Zhang, J.-D. Hamel and L. L. Schafer, Chem. - Eur. J., 2013, 19, 8751; (l) P. Garcia, P. R. Payne, E. Chong, R. L. Webster,
B. J. Baron, A. C. Behrle, J. A. R. Schmidt and L. L. Schafer, Tetrahedron, 2013, 69, 5737; (m) J. Dörfler and S. Doye, Eur. J. Org. Chem., 2014, 2790; (n) E. Chong, J. W. Brandt and L. L. Schafer, J. Am. Chem. Soc., 2014, 136, 10898.

6 Zirconium catalysts: J. A. Bexrud, P. Eisenberger, D. C. Leitch, P. R. Payne and L. L. Schafer, J. Am. Chem. Soc., 2009, 131, 2116.

7 Titanium catalysts: (a) C. Müller, W. Saak and S. Doye, Eur. J. Org. Chem., 2008, 2731; (b) R. Kubiak, I. Prochnow and S. Doye, Angew. Chem., Int. Ed., 2009, 48, 1153; (c) I. Prochnow, R. Kubiak, O. N. Frey, R. Beckhaus and S. Doye, ChemCatChem, 2009, 1, 162; (d) R. Kubiak, I. Prochnow and S. Doye, Angew. Chem., Int. Ed., 2010, 49, 2626; (e) I. Prochnow, P. Zark, T. Müller and S. Doye, Angew. Chem., Int. Ed., 2011, 50, 6401; (f) D. Jaspers, W. Saak and S. Doye, Synlett, 2012, 23, 2098; ( $g$ ) J. Dörfler and S. Doye, Angew. Chem., Int. Ed., 2013, 52, 1806; (h) T. Preuß, W. Saak and S. Doye, Chem. - Eur. J., 2013, 19, 3833; (i) J. Dörfler, T. Preuß, A. Schischko, M. Schmidtmann and S. Doye, Angew. Chem., Int. Ed., 2014, 53, 7918; (j) E. Chong and L. L. Schafer, Org. Lett., 2013, 15, 6002.

8 (a) T. Elkin, N. V. Kulkarni, B. Tumanskii, M. Botoshansky, L. J. W. Shimon and M. S. Eisen, Organometallics, 2013, 32, 6337; (b) T. Elkin, M. Botoshansky, R. M. Waymouth and M. S. Eisen, Organometallics, 2013, 33, 840; (c) L. R. Groom, A. F. Russell, A. D. Schwarz and P. Mountford, Organometallics, 2014, 33, 1002; (d) N. V. Kulkarni, T. Elkin, B. Tumanskii, M. Botoshansky, L. J. W. Shimon and M. S. Eisen, Organometallics, 2014, 33, 3119 and references cited therein.

9 F. R. Leroux, B. Manteau, J.-P. Vors and S. Pazenok, Beilstein J. Org. Chem., 2008, 4, 13.

10 H. Fujita, M. Tokuda, M. Nitta and H. Suginome, Tetrahedron Lett., 1992, 33, 6359.

11 D. Weickmann, W. Frey and B. Plietker, Chem. - Eur. J., 2013, 19, 2741.

12 R. T. Gephart III, D. L. Huang, M. J. B. Aguila, G. Schmidt, A. Shahu and T. H. Warren, Angew. Chem., Int. Ed., 2012, 51, 6488. 